\title{
The Collateral Source Rule and Loss Allocation in Tort Law
}

\author{
John G. Fleming*
}

$\mathrm{H}$ IGH RANKING among the oddities of American accident law is the so-called "collateral source" rule which ordains that, in computing damages against a tortfeasor, no reduction be allowed on account of benefits received by the plaintiff from other sources, even though they have partially or wholly mitigated his loss. Standing alone this looks perhaps unexceptionable enough. Its sting lies in the corollary that the plaintiff may ordinarily keep both the damages as well as the collateral benefit and thus turn his plight into a bonanza.

The problem is a by-product of the affluent society. In olden days an accident victim would rarely have been able to draw to any substantial extent on outside sources for meeting his expenses and making up for his loss of earnings during disability. Very occasionally he might have possessed an accident pohicy, and perhaps a hittle life insurance. Even then, it makes no undue demand on one's imagination to surmise that, at any rate, prior to the advent of the automobile, most people who stood $\mathrm{m}$ the way of torts belonged-as they still largely do-to the lower orders who would rarely have had the providence, even if they had commanded the means, to pay for insurance. However that may be, the accident victim would ordinarily have had to resign limself to drawing upon his own savings or throwing himself upon charity-which at best was random in incidence and meager in dimension. Other sources there were none: tort law provided the principal, usually the sole, source of compensation for injuries suffered.

The welfare state has changed all this. Today's victims of misfortune may count on a number of funds to alleviate their distress, foot part or all of their medical expenses and assure at least iminimum standards of subsistence. In varying measure, all advanced countries nowadays maintain social security programs for those who suffer disability, whether from illness or accident, including of course tortious accident. The largest segment of injuries by far-that of work injuries-has for so long now been under the peculiar regime of workmen's compensation that most lawyers are prone not to think of it at all as part of personal injury lawall the easier when, as in the United States (tlough by no means in all countries), compensation has become the exclusive remedy against the

* B.A., 1939, M.A., 1943, D.Phil., 1948, D.C.L., 1959, Oxford University; Professor of Law, University of California, Berkeley. 
employer (and, often, against the culpable fellow-employee), and tort claims arising from work injuries are available only against third parties, sucl as independent contractors engaged on the same job or negligent drivers causing injury to employees in traffic. With respect to other kinds of accidents, it is true that the American Social Security system has lagged considerably behind that of most other countries in the limited range of provision it makes for disability by other than the aging or aged. ${ }^{1}$ No doubt, this accounts in large measure for the lack of concern, indeed widespread unawareness, of the problem of cumulated benefits in the public welfare sector. Such attention as it has received rather relates to the large number of servicemen and veterans who are entitled to considerable benefits, including not only free medical treatment, but also, in the case of the former, continued full pay during temporary disability or pensions im graver cases.

Most important of all, however, though most likely to be all-butforgotten, is the swelling volume of fringe benefits in collective and private labor contracts ${ }^{2}$ wlich typically assure employees the benefit of health plans, such as Blue Cross, Blue Shield, or Kaiser Foundation, thus meeting all or most of their medical expenses in case of illness or accident, howsoever caused, besides pending disability or retirement pay. ${ }^{3}$

I The federal Social Security Act makes provision only for permanent and total disability. This program, originating as late as 1952, was at first content with "freeze" provisions alone, 66 Stat. 767 (1952). Not until 1956 were any actual disbursements made available, 70 Stat. 815 (1956), 42 U.S.C. $\$ 423$ (1964), and prior to 1961 for persons over the age of 50 only. 70 Stat. 815 (1956). More generous provision covering also temporary disability from causes other than work-injuries has remained the prerogative of railway employees under the federal Railroad Unemployment Insurance Act, 52 Stat. 1094 (1938), as amended, 45 U.S.C. § 351-62 (1964). In addition, there are now seven states which provide limited programs of their own, complementary to unemployment insurance and funded by employer-employee contributions. These include California, New Jersey, New York and Rhode Island, embracing programs which, in 1962, expended over 400 million dollars. Special plans for temporary disability of public employees are mentioned below in note 3. See generally RIESENFEId \& MAXWEIL, MODERN SoctaL Legislation (1950, Repl. Pamphlet 1958) (see particularly id. at 443-48); RIISENFEID, Aktuelle StröMrungen UND Bestrebungean IN der Soztalgesetzgerung der USA (Munich, 1965).

2 Typical collective labor agreenıents, and their provision for medical benefits, disability pay, etc., are the Ford Motor Co. Agreement (reprinted in 87 MONTHLY LABOR REVIEW 1039-1050 (1964)) and U.S. Steel Agreement (reprinted in 88 MoNTHLX LABOR REVIEW 178-189 (1965)).

3 The magnitude of this effort may be gauged from the following statistics: In 1962 71.4\% of all workmen and employees were covered against hospital costs, $68.4 \%$ against surgical and $54.9 \%$ against ordinary medical expenses under these private "social security" plans. The total expenditure pursuant to voluntary plans in 1962 amounted to no less than 9.555 billion dollars, of which 2.15 billion were attributable to retirement pay and 5 billion to medical costs. This represented $5.5 \%$ of the total wage bill of private industry, $85 \%$ being defrayed by employers. The coverage for public employees, federal, state and local, is even more impressive. In 1962 it was estimated that $84 \%$ were covered by sick-leave 
This form of "private sector" welfare, by bridging the gap which elsewhere is covered by more comprehensive "public" social insurance systems, is for that reason not only all the more important in its social impact, but also tends to go largely unnoticed in legislatures and courts, which in all probability would be more alert to the needs for economy and rationalization if the public purse were involved.

Tort recovery has thus long ceased to be the only, or even the principal, source of repairing accident losses, besides the private resources of the victim himself. More typically today, some or all of the losses will have been taken care of by one or more of the above-mentioned funds long before the mjured party gets within the reach of what the slow and cumbrous common-law process may eventually afford hin by way of tort damages. This has had several quite profound effects. Foremost, perhaps, is that it has relaxed the pressure which would otherwise have been exerted on the law of torts to afford a much larger measure of social security in response to increasing popular expectations. In 1949 Professor Friedmann ${ }^{4}$ ventured the hypothesis that the marked aversion he noticed among English courts in the immediate post-war period to notions of strict liability was not unconnected with the contemporaneous adoption of welfare-statism associated with the Beveridge Report of 1942.5 On the same lines, it would not be an entirely idle speculation to ascribe the unmistakable and progressive trends toward "enterprise liability" in the last ten years of American case law-completely without parallel in Britain and other countries of Western Europe-at least in some part to the lesser provision of social security through public welfare legislation in the United States. In other words, tort law has had to shoulder a larger share of repairing economic distress. Yet, in view of the marked disparity alone between the relatively modest benefits social security affords and the comparative bonanza placed in the reach of those for whoin fortune's lucky throw of the dice lias opened the door to tort recovery, questions whether the latter really deserve so much larger a share of society's bounty and to what extent become increasingly more urgent. They cannot, however, be investigated here-I have recently souglit at least to open such an imquiry elsewliere - except insofar as they impinge on our

plans. Skolnick, Income-Loss Protection against Short-Term Sickntess, 1948-62, 27 Soc. Sec. Bull., No. 1, p. 4 (1964) ; Krislov, Employee-Benefit Plans, 1954-1962, 27 Soc. Sec. Bull., No. 4, p. 4 (1964).

4 Friedmann, Social Insurance and the Principles of Tort Liability, 63 HARv. L. REv. 241 (1949).

- Inter-Departmental Committee on Social Insurance and Allied Services, Report, CaD. No. 6404 (1942).

${ }^{6}$ Fleming. Law of TORT and Irs Soctax Funcrion Ch. 1 (1966). Some other writers have of course done the same: e.g. Blum \& Kalven, Public Law Perspectrves on a Private LAW ProBiEMS (1965). 
instant concern with whether it is consistent with a proper distribution of accident losses that the victim should both retain the lesser social welfare benefits as well as the full measure of tort recovery froin the tortfeasor.

The second most important consequence, then, of the coexistence of compensation regimes other than tort hability is that it compels a decision on whether benefits shall be cumulative, alternative or stand in some other relation. This is looking at it from the poimt of view of the accident victim. In the larger perspective of loss distribution, we are compelled to face the issue of to what extent, if at all, "risk communities" other than that represented by the tortfeasor ought to participate in bearing the loss. If, for example, the tortfeasor's hiability were to be reduced by the anount of social security benefits accruing to him-the solution which substantially prevails under the English law-the general community would shoulder a part of the loss, relieving pro tanto the specific risk-creating activity (motoring, manufacturing, etc.) represented by the defendant. If, on the other hand, as happens to be the predominant approach in most other countries, it is felt that the public purse ought to be relieved if at all feasible and proper, attention will have to be focused on ways to reallocate to the tortfeasor expenses already borne by the public fund, not to speak of the tortfeasor's assuming all obligations for the future. Only an entirely neutral, laissez-faire legal system could abide the accident victim retaining the full benefits of both.

In order to gain an impression of the order of magnitudes here involved as they relate to the American scene, we may usefully refer to findings in the recently completed Michigan study of automobile accidents ${ }^{7}$ which reinforced with awesome statistical authority hunches already widely shared among less scientific observers. According to this survey, collateral sources account for almost half of the compensation received by injury victims: Only fifty-five per cent of the aggregate compensation derived from tort hability settlements, while twenty-one per cent came from automobile insurance, twelve per cent from medical and five per cent from life insurance; the remaining seven per cent derived from social security of one kimd or another, including workmen's compensation for traffic accidents on the way to and from work. ${ }^{8}$ The share

7 Conard, Morgan, Pratr, Volzz, Bombaugh, Automobite Accidents Costs and Payarents (1964) [hereinafter cited as Conard, Automsobie Accionsts].

8 Id. at 147, Tables 4-9. Strikingly similar are the findings of an Ontario study of automobile accidents in York County (including Metropolitan Toronto) in 1963. Of total recoveries, non-tort sources accounted for just under $40 \%$. The most important of these is free hospital treatment by the Ontario Hospital Commission, to which in the future will now have to be added the new medicare benefits just introduced. Unfortunately this study does not present a clear picture of overcompensation, partly because compensation in 
reportedly borne by non-tort sources of compensation is, it will be noted, the more impressive because it does not for all practical purposes include the largest of these sources, workmen's compensation. Moreover, while it is true that thirty-eight per cent of the accident bill was footed by the victims' own private insurance and only seven per cent from "social security" plans, the latter have been and still are increasing their benefits at a much faster rate than other regimes and must therefore be credited with a correspondingly greater irnpact in the future.

More revealing yet for purposes of the present discussion is that about half of the serious injury victims are reimbursed less than one-half their monetary losses, whereas a substantial percentage in the lower and especially in the lowest range of mjury are over-compensated at rates up to five times their economic loss. ${ }^{9}$ Clearly, this capricious maldistribution of compensation cannot be explained solely on the ground that damages for pain and suffering account for so large a quotient, even if it were allowed that the ratio between the two items of damage is higher in the lower ranges of injury than in the upper. In appreciable measure this discrepancy is attributable to the collateral source rule whose impact is rnost noticeable in the lower ranges because most collateral benefits are flatrated and fairly modest in amount. When I spoke of maldistribution, I meant of course to imply nothing more or less than that the amount of economic wealth now available for accident compensation is not being distributed (sufficiently) on the basis of need.

It is not the primary purpose of this article to reexamine the collateral source rule as such. Suffice it to say that, to the extent of its overwhelming acceptance in this country, ${ }^{10}$ it represents a clear-cut choice

excess of economic loss is in most cases attributable to damages for pain and suffering. Besides, there is less occasion for it because Canadian law reduces the tortfeasor's liability by most collateral benefits, including free medical treatment. LINDEN, REPORT OF THE OSGGODE Hail Study on Compensation for Victoms of Automobie Accidents (1965).

${ }^{9}$ Id. at $175-80$. A previous study of Pennsylvania automobile accidents in 1956 reveals a similar picture. While $23.9 \%$ of victims received no form of compensation whatever, $17.3 \%$ received more than 5 times, and $19.9 \%$ between 2 and 5 times their "tangible" losses. Morris \& Paul, The Financial Impact of Automobile Accidents, 110 U. PA. L. REv. 913, 921 (1962).

10 See Harper \& James, Torts $\$ 25.22$ (1956); Maxwell, Collateral Source Rule in the American Law of Damages, 46 Mrvr. L. REv. 669 (1962); Schwartz, The Collateral Source Rule, 41 B.JL. REv. 348 (1961), reviewing the New England cases. Most perceptive also is the Note, Unreason in the Law of Damages: The Collateral Source Rule, 77 Harv. L. REv. 741 (1964). The Restatement of Torts betrays an attitude of coy ambivalence. Section 901 enumerates among purposes of tort law, relevant to assessing damages, ". . (a) to give compensation, indemnity or restitution for harms; ... (c) to punish wrongdoers." But the explanations in the accompanying comment do not suggest that subsection (c) was intended to justify the collateral source rule. Nor is there any black-letter rule which sanctions it; only a pallid and well-hidden paragraph in $\$ 920$, comment $e$. References to the relevant case law will be found infra note 85 (insurance), note 70 (wages and pensions), 
that the tortfeasor has no claim to being relieved of any portion of his liability by reason of somebody else's ${ }^{11}$ contribution to the accident bill. The constantly recurring refrain, with strong overtones of moral outrage, is that the defendant is a wrongdoer who should not be "let off" from any portion of what is his due by the exertions and foresight of his victim or those who stood by him in his hour of need. To anyone a little troubled by the notion that this might mean double recovery for the plaintiff, the stereotyped response has been that this is still better than letting the defendant profit, ${ }^{12}$ and that, in any event, the damages awarded to a plaintiff at least in personal actions never fully indemnify him for his loss, especially when account is taken of the fact that a large slice of it will find its way into the pocket of his attorney.

In view of the manifest strength and sincerity with which this viewpoint is entertained, it might be thought idle, if not tactless, to challenge the assumptions on which it evidently rests. Otherwise it might have been pointed out that the deterrent thrust of tort liability would liardly be impaired by hind-knowledge of a collateral contribution nor, for that matter, even by fore-knowledge that the cost might be lessened a little. Moreover, it might have been stressed that the amount of liability lias never been proportioned to the degree of the defendant's heinousness,

note 71 (medical expenses), and note 161 (social security). The collateral source rule enjoys no lesser vogue as a rule of federal law. See, e.g., Gypsum Carriers, Inc. v. Handelsman, 307 F.2d 525 (9th Cir. 1961) (Jones Act, maintenance and cure); Sinovich v. Erie R.R., 230 F.2d 658, 661 (3d Cir. 1956) (Federal Employers Liability Act).

11 "Collateral" means any source other than the defendant himself. The mere fact that the latter has paid contributions to a fund or scheme is not sufficient to justify set-off, as illustrated by the decisions that the benefit of accelerated pensions under the Railroad Retirement Act does not reduce a railroad's liability to an injured employee under the Federal Employers Liability Act. N.Y., N.H. \& H. R.R. v. Leary, 204 F.2d 461 (1st Cir. 1953), Sinovich v. Erie R.R., 230 F.2d 658 (3d Cir. 1956). On the other hand, a medical payments coverage in the defendant's policy is generally held deductible. See note 86 infra.

Where the United States is the defendant under the Federal Tort Claims Act, the question whether benefits under some social welfare program should be treated as collateral ought to be resolved according to one view by the formula that "mjury-related benefits paid from unfunded general revenues are to be deducted and similar benefits paid from a special funded source are not." United States v. Hayashi, 282 F.2d 599 (9th Cir. 1960). Thus free treatment in a Veterans hospital is deductible, but a Social Security benefit is not. But see Feeley v. United States, 337 F.2d 924 (3d Cir. 1964), where the court looked to state (Pennsylvamia) law.

$12 \mathrm{~A}$ couple of random samples convey the flavor of the prevailing attitude: "The wrongdoer is not permitted to obtain a windfall by reason of the principle that an injured person should be compensated only once." Dodds v. Buckman, 214 Cal. App. 2d 206, 214, 29 Cal. Rptr. 393, 398 (1963). And again: "This may permit a double recovery, but it does not impose a double burden. The tortfeasor bears only the single burden for his wrong. That burden is imposed by society, not only to make the plaintiff whole, but also to deter negligence and encourage due care." Gypsum Carriers v. Handelsman, 307 F.2d 525, 534 (9th Cir. 1962). 
but only to the fortuitous amount of the damage done-that a defendant would always get a "windfall" however negligent his conduct, if he happened to kill a bachelor without family commitments, in contrast to a young pater familias with long prospects and even longer progeny. Furthermore tort hability is fast shedding the last vestiges of any punitive function as policies of enterprise liability and loss distribution are increasingly pushing into the background individualistic notions of personal responsibility and guilt. ${ }^{13}$ Finally, and for good measure, it might have been added that so cavalier a compromise with the fundamental axiom that the lallmark of tort damages is compensatory, is but a sad reflection of the fact that, in this instance at least, American courts have shown themselves less than equal to the task of responsible social engineermg, allowing themselves to be distracted from urbane decisions about loss distribution by appeals to a simplistic and irrelevant morality. Certainly, the fact that American jurisprudence stands here in virtually splendid isolation should give pause to those who would otherwise be tempted to mistake their solution for a self-evident truth.

But then, by all means, let it be assumed that the tortfeasor should not get away with paying less than the full measure of the loss which he has caused. This still would not necessarily entail the consequence that the person injured slould, on the final count, get more than a complete indemnity for his net loss. For this tripartite situation-involving the injurer, the injured, and his collateral benefactor-offers several opportunities for reallocating or shifting the loss in sucl a manner that, in the last resort, it burdens the tortfeasor without however enricling his victim. One of the endemic flaws of the debate over the collateral source rule is precisely that it has been blinkered by the fatalistic assumption, borne with resignation, that the choice is limited to either set-offwhicl would confer a windfall on the ill-deserving defendant-or no set-off-which would confer a corresponding windfall on the wronged plaintiff. That the problem should be seen in the form of this dilemma is readily understandable because the issue would ordinarily be raised by the plaintiff or defendant in the tort action. Any further slifting of the loss would ordinarily require initiative either from the third partythe collateral source-or from the court itself on its own motion. The former could, but rarely cloes, intervene; the latter alternative runs counter to deeply ingramed prejudices of the common law adversary system as practiced, at any rate, in the United States, in contrast to the inore "administrative" flavor of the continental and even English legal tradition.

13 Yet what little authority there is does not support any sanguine belief that the rule would not apply against a non-negligent tort defendant liable on a theory of strict liability. See note 241 infra. 
It is the purpose of this article in the first instance to explore the various means that can be-and in one place or another have been-employed in order to accomplish this more sophisticated reallocation. Broadly, it may take one of three possible forms: first, by conferring on the collateral source a right to indemnification, whether by subrogation, assignment or an independent claim against the tortfeasor; second, by the latter returning the benefit to his benefactor, as in the not infrequent case of conditional loans or gifts reverting to the lender or donor; and third, in the case of otherwise continuing benefits, like periodic payments, by terminating these as soon as tort damages assure full indemnity for the future.

I

INDEMNITY, SUBROGATION AND OTHER IIKE TECHNIQUES

\section{A. Action for Loss of Services}

Historically the oldest remedy for a third party seeking reimbursement from a tortfeasor for losses suffered or expenses incurred by him as the result of injury inflicted on the primary victim of a tort is the hoary action for loss of services. Conceptualistically rooted in the feudal notion that a master had a proprietary right, if not in the servant, at all events in his services, it vindicated his exclusively economic interests against injury resulting from his servant's disablement. Primarily, his recovery would comprise the cost of nursing and maintaining the servant as a member of the household until he regained his utility by once again rendering worthwhile services. There was no question of vindicating any dignitary interest in the case of ordinary domestics, although in the off-shoot parental action for injury to a child (which throughout its history proceeded on the fiction that the child was a servant who, if not actually rendering services, was legally under a duty to do so if called upon) the parent might recover for hurt feelings and, in case of a daughter's seduction, for damaged familial pride. ${ }^{14}$ In the ordinary accident case the action-whether brought by master or parent (per quod servitium amisit) or husband (per quod consortium amisit) - secured recovery only for the actual pecuniary loss that resulted from the inferior's disability: perhaps the extra cost of hiring substitute or extra home help, but primarily the ordinary cost of maintaining the injured individual without any corresponding benefit from his services, plus any actual disbursements hike doctor's bills. The last two items are of course most relevant to the present discussion, being forerunners of the modern fringe

14 This is memorably expressed in the saying "The Plaintiff comes into court as a master-he goes before the jury as a father." Briggs v. Evans, 27 N.C. 13, 16 (1844). See Prosser, TorTs 907 (3d ed. 1964); Fleming, TORTs 620-21 (3d ed. 1965). 
benefits of disability pay and free or subsidized medical treatment afforded by so many employers during employees' disability.

But given such mauspicious antecedents, did the action survive the peculiar social relations from which it stemmed once capitalism had supplanted feudalism as the basic economic order and individualism repudiated the morahity of subordination ${ }^{15}$ Was it not at least to be confined to apprentices and laborers living under the master's roof on the farm or in cottage industry? The law reports bear scant witness of any cliallenge to the ancient precedents except for an isolated dictum in $1795^{10}$ which would have restricted the action to menial servants-the modern counterpart, no doubt, of the kind of relation from which it originated. Yet im 1832 a claim succeeded with respect to a servant described as a "traveler or servant."17 During the nineteenth century the issue evidently remained in abeyance. All that became clarified was that the action was not available in cases of wrongful death, ${ }^{18}$ and, partly to mitigate this conclusion, Lord Campbell's Act, which conferred an action on designated surviving relatives for loss of their dependency througl fatal accidents, was passed in 1846.

A foretaste that the future would be influenced by changing notions of judicial policy rather than inherited tradition emerged from the dramatic development of the related action for intentional traducing of servants. Despite its close link with the Statute of Laborers, passed to deal with the shortage of manual labor in the wake of the Black Death in the middle of the fourteenth century, ${ }^{10}$ this action was extended first, in 1856 , to the noted operatic soprano, Miss Johanna Wagner, who was induced by a competitor to break her engagement to sing at Covent Gardens. ${ }^{20}$ The action was finally generalized to support claims for unjustifiable inducement of all breaches of contract, even those having nothing to do whatever with a service relationship. Thus was born the "new" tort of intentional interference with advantageous economic relations. ${ }^{21}$

All the more startling, by contrast, was the cool, indeed hostile, re-

15 The history is traced with a wealth of detail by G. Jones, Per Quod Servitium Amisit, 74 L. Q. Rev. 39 (1958); see also Dixon, C. J., in Commissioner for Rys. (N.S.W.) v. Scott. 102 Commw. L.R. 392, 397-403 (Austl. H.C. 1959).

16 Taylor v. Neri, 1 Esp. 386, 170 E.R. 393 (C.P. 1795).

17 Martinez v. Gerber 3 Man. \& G. 88, 133 E.R. 1069 (C.P. 1841).

18 Baker v. Bolton, 1 Camp. 493, 170 Eng. Rep. 1033 (K.B. 1808); Osborn v. Gillett L.R. 8 Ex. 88 (1873). See also Malone, Genesis of Wrongful Death, 17 Staw. L. Rev. 1043 (1965).

10 For the history of the action, and particularly its controversial relationship to the Statute of Labourers, 1348, see G. Jones, Per Quod Servitium Amisit, 74 L.Q. REv. 39 (1958).

20 Lumley v. Gye, 2 El. \& Bl. 216, 118 E.R. 749 (1853).

21 See Frencrug, Torts 651 (3d ed. 1965). The parallel American development is treated by Prosser, TORTs 952-73 (3d ed. 1964); 1 HARper \& JaMrs, TorTs $\$ \S 6.6-6.9$ (1956). 
sponse to the action for loss of services which, by 1916, was being castigated as "anomalous" and "anachronistic."22 Sufficient a reason for so disparate a treatment was that the latter concerned claims for unintended harni; and the common law, in company with most other legal systems, preferred as a matter of general policy to confine liability for negligence to the immediate victim, denying its protection to those who might suffer, however foreseeably, economic detriment because of their relation to the viction. ${ }^{23}$ If the burden was generally thought to be excessive, there was no particular reason for any exception in favor of employers, ${ }^{24}$ and this attitude came to dominate henceforth the judicial treatment of the old action for loss of services, alike in Britain as in the United States.

Almost all the British and American twentieth century cases that have found their way into the reports involve claims for reimbursement of disability pay or pensions and cost of medical treatment for members of the armed services, police force or other public servants. The significance of this feature lies in the predominant concern it reveals on the part of these employers to reclaim actual expenditures in looking after disabled employees; a concern that gained added meaning from the fact that these fringe benefits, until recently the exclusive reward of public service, are fast becoming a commonplace in most collective and even private employment contracts, at least in pace-setting industries.

This immediately raises the question whether the action, whatever its primary purpose in the past, should not be put to the service of this newly revealed, modern need. Hence, occasional protestations of judicial hostility based on pretended moral outrage over the original philosophical foundation of the action are really totally irrelevant to the current debate. ${ }^{25}$ As the Marxist jurist Karl Renner, later President of the Austrian Republic, pointed out in his great work on The Institutions

22 The Amerika, [1917] A.C. 38. "Indeed, what is anomalous about the action per quod servitium amisit is not that it does not extend to the loss of services in the event of the servant being killed, but that it should exist at all." Id. at 60 (Lord Sumner).

23 See Frencting, Torrs 174, 648 (3d ed. 1965).

24 This sentiment was most emphatically voiced by the House of Lords in The Amerika, [1917] A.C. 38, and, agam, by the Privy Council in Attorney Gen. for New South Wales v. Perpetual Trustee Co. [1955] A.C. 457 . In defeating a claim by a wife for loss of her injured husband's prowess, the House of Lords again involked the same prejudice against relational claims for negligent, as distinct from intended, mjury. Best v. Fox, [1952] A.C. 716.

25 That this is occasionally acknowledged even by judges is attested by the following observation: "In some recent discussions of the scope of the action . . . it has been stated that the action is out of harmony with the economic and social conditions of to-day. This seems to me to be, in the abstract, a questionable assertion, especially if by such an action an employer is entitled to recover from the wrongdoer medical expenses he paid for, and wages he paid to, an injured servant. ... [S]uch a right to be indemnified ... is well recognized in workmen's compensation law." Commissioner for Rys. (N.S.W.) v. Scott, 102 Commw. L.R. 392, 439-40 (Austl. H.C. 1959) (concurring opinion of Windeyer, J.). 
of Private Law, ${ }^{26}$ not infrequently a legal institution (his prototype being property) outlives its original design, but instead of withering away is employed to serve a different social function and thus gains a raison d'etre for useful survival. ${ }^{27}$ Should the action for loss of services be added to this list?

Courts have been far from answering this question with one voice. Bias against the action has manifested itself along two principal lines of objection. In the first place, there has been a growing trend to disqualify the action in regard to certain kinds of employment, especially those where the employers' interests are apt to be most vitally concerned. In a sense rather incongruously, the first round in this campaign of retrenchment concerned an Australian serviceman, a claim for the cost of whose medical treatment and pay during disability was dismissed on the ground that the relation between a soldier and the Crown offered no meaningful analogy to the sort of service contemplated by the action. ${ }^{28}$ Incongruously, because one miglit well have been pardoned for considering military subordination the closest conceivable modern counterpart of the feudal relation between a master and his man. Interestingly enough, the same conclusion was reached quite independently a few years later by the United States Ninth Circuit Court of Appeals when rejecting a similar claim involving an American soldier injured on furlough in California on the ground that lie did not qualify as a "servant" for the statutory cause of action for loss of services under the California Civil Code, ${ }^{20}$ since lie lacked the freedoin of a servant to enter or leave his employment at will! ${ }^{30}$ The Supreme Court, in dismissing an appeal, ${ }^{31}$ did so, however, on the different ground that federal law controlled but that Congress had failed to provide a remedy. In so ruling, the court was evidently content with the taxpayer footing the bill of affording double compensation for the injured soldier. ${ }^{32}$

\footnotetext{
26 Renner, The Institutions of Private LaW and Their Soctal Functions (1949), with a most perspicacious introduction by Professor O. Kahn-Freund.

27 I had the temerity to raise this suggestion nearly fifteen years ago in The Action Per Quod Servitium Amisit, 26 AUsin. L.J. 122 (1952). Nothing in the meantime has detracted from its relevance.

28 Commonwealth v. Quince, 68 Commw. L.R. 227 (H.C. Austl. 1944). A contrary conclusion had recently been reached in Ireland (Attorney Gen. v. Dublin Unitcd Tramways, [1939] Ir. R. 590). See Cowen, The Consequences of Commonwealth v. Quince, 19 AUSTI. L. J. 2 (1945).

20 CAI. Crv. Code $\S 49$ : "The rights of personal relations forbid: ... (c) Any injury to a servant which affects his ability to serve his master. ..."

30 Standard Oil Co. v. United States, 153 F.2d 958 (9th Cir. 1946).

31 United States v. Standard Oil Co., 332 U.S. 301. (1947).

32 The Supreme Court of Canada clearly viewed the matter with a different eye in holding that, a member of the Canadian armed forces heing a "servant of the Crown," Exchequer Court Act, CaN. Rev. STat. ch. 34, § 50A (1927), an action for loss of his services would lie to recover the cost of his hospitalization, etc. The King v. Richardson;
} 
Next in line for disqualification were policemen in a case which, agam starting from Australia, ${ }^{33}$ eventually reached the Judicial Committee of the Privy Council ${ }^{34}$ and gave that august body an opportunity to pronounce the action inapplicable to public as distinct from "menial" service. This somewhat Delphic dictun was quickly seized by the English Court of Appeal as a mandate to limit the action to "memal servants," meanimg domestics, ruling first against an income tax inspector, ${ }^{35}$ and clinching the matter in the case of a company director. ${ }^{36}$ Oddly enough, to complete the British side of the story, the Australian High Courtwhich started it all-then slowed itself unwilling to go as far as the English courts, interpreting what the Privy Council had said to mean only that the action was confined to the memal relation of master and servant, not to the relation of master and menial servant. ${ }^{37}$ Accordingly, it allowed the claim for injury to an engine driver in the employ of the New South Wales government railways. ${ }^{38}$ Thus the matter remains in abeyance, with most commonwealth courts outside Australia hewing to the English line which, for all practical purposes, has thus buried the action without even a decent ritual. ${ }^{39}$

[1948] Can. Sup. Ct. 57, [1948] 2 D.L.R. 305; Attorney Gen. v. Nykorak, [1962] Can. Sup. Ct. 331, 33 D.L.R.2d 373. Note also that the effect of disallowing the claim in England is to relieve the tortfeasor, not to overcompensate the soldier. Neither then nor now would the United States Government lave sought reimbursement from the soldier himself.

33 Attorney Gen. for New South Wales v. Perpetual Trustee Co., 85 Commw. L.R. 237 (Austl. H.C. 1952), refusing to follow the contrary English decisions of Bradford Corp. v. Webster, [1920] 2 K.B. 135, and Attorney Gen. v. Valle-Jones, [1935] 2 K.B. 209.

${ }^{34}$ Attorney Gen. for New South Wales v. Perpetual Trustee Co., [1955] A.C. 457. The writers have been less than enthusiastic about this development. See Cowen, The Action Per Quod Servitium Amisit and the Police, 2 U.W. AUSTL. ANN. L. REv. 263 (1952); Fleming, The Action Per Quod Servitium Amisit, 26 AUSTL. L.J. 122 (1952); Notes by Sawer, 18 MODERN L. REv. 488 (1955); Goodhart, 71 L.Q. REv. 308 (1955).

35 Inland Revenue Comm'rs v. Hambrook, [1956] 2 Q.B. 641.

36 Lee v. Sheard, [1956] 1 Q.B. 192.

37 Commissioner for Rys. (N.S.W.) v. Scott, 102 Commw. L.R. 392 (Austl. H.C. 1959). 38 Ibid.

39 Eire, though not technically in the Commonwealth, reversed its own previous stand in Attorney Gen. v. Ryan's Car Hire Ltd., 99 Ir. L.T. 117 (Sup. Ct. 1964). Canadian authority is perplesingly ambiguous: On the basis of $\$ 50$ of the Exchequer Court Act, deeming a member of the Canadian armed services to be a "servant of the crown," the Supreme Court held the action applicable to an injured soldier, The King v. Richardson, [1948] Can. Sup. Ct. 57, [1948] 2 D.L.R. 305, and this was reaffirmed in Attorney Gen. v. Nykorak, [1962] Can. Sup. Ct. 331, 33 D.L.R.2d 373, despite the fact that a soldier, though deemed a "servant," was obviously not a menial servant. Apparently unaware of this decision, or at least its implications, an Ontario court adopted the English doctrine (Crone v. Orion Ins. Co., [1965] 2 Ont. L.R. 431, 51 D.L.R.2d 27 (H.C.); aff'd, [1966] 1 Ont. 221, 53 D.L.R.2d 98 (C.A.), but an Alberta court expressly repudiated it (Kneeshaw v. Latendorff, 53 West Weekly R. 672 (Alberta Sup. Ct. 1965) (bakery employee)).

Israel also fell into line in 1954 (soldier) and 1956 (private employee): Vieder v. Attorney Gen., 10 Pieskei-Din 1246; Jewisll Agency v. Shechter, 11 Pieskei-Din 1329; cited in 29 MODERN L. REv. 42, 44 (1966). 


\section{American Experience}

To date, there has been little or no specific American reaction to these developments. Admittedly, authoritative documentation concerning the action for loss of services has always been sparse. Until well past the turn of the twentieth century, textbooks certainly discussed the action without any noticeable reservation; ${ }^{40}$ and codifications, like the Field Code of California, enacted it as an entrenched part of the common law. ${ }^{41}$ The very dearth of case law, ${ }^{42}$ however, provided more than a straw in the wind that the action was rarely if ever used. To account for this one does not have to look for any explanation other than that the prevailing condition of the labor narket where the worker was chasing jobs and the absence of welfare clauses in private employment contracts (aside from workmen's compensation covering injuries on the job) were not conducive to any loss by the employer such as would have been necessary to support the action. Yet what was really only a state of suspense could easily be interpreted as obsolescence, especially by a legal profession with no pronounced sense of historicism and naturally unsympathetic to the alien aura surrounding the action. ${ }^{43}$

Modern judicial response has accordingly ranged from tepid to hostile. Althougl the record is thin and unimpressive, consisting mainly of unconsidered dicta, the inevitable impression is of a pervasive desire to repudiate the action. ${ }^{44}$ Paralleling the British experience, most of the

Independently the same position was reached for Roman-Dutch law in South Africa (Union Gov't v. Ocean Acc. \& Guarantee Corp., [1956] 1 So. Afr. L.R. 577) and Scots Law (Reavis v. Clan Line Steamers, Ltd., [1925] Sess. Cas. 725 (Scot. 1st Div.)).

40 E.g., 7 LabatT, Master and Servant 8096 (2d ed. 1913).

41 CAL. CTv. Code $\S$ 49. At least two other states have similar statutes: GA. Code ANv. tit. 105, § 106 (1948); 76 OkLA. STaT. ANw. tit. 76, § 8 (1965).

42 The few reported decisions support the action: Woodward v. Washburn, 3 Denio 369 (N.Y. Sup. Ct. 1848) (half hour's imprisonment: six cents); Ames v. Union Ry., 117 Mass. 541, 19 Am. Rep. 426 (1875) (apprentice); Campbell v. Cooper, 34 N.H. 49, 68 (1856) (dicta); Fluker v. Georgia R.R. \& Banking Co., 81 Ga. 461, 8 S.E. 529 (1889) (dicta).

43 Thus Seavey comes out holdly that "it would appear that American lawyers have not believed in the existence of such a cause of action. It would appear, therefore, that this action is obsolescent and that there is no valid reason for reviving it." This summation in a note, Liability to Master for Negligent Harm to Servant, originally published in 1956 WASE. UI.Q. 309, 313, and republished in RESTATEMEENT (SECOND), AGENCY, app., 532 (1958), contrasts with the unore cautious Caveat to section 316 of the Second Restatement of Agency: "[No] statement is made as to whether a person who tortiously causes physical harm to a servant is liable to the inaster." Comnent $b$ to section 316 resigns itself to the observation that "there are few modern cases allowing such an action and even fewer unodern cases denying it." Leon Green, like Seavey, has given his opinion that "the suit has practically fallen out" in Green, Relational Interests, 29 Irr. L. REv. 1041, 1042 (1935).

44 One modern decision at most can be marshalled to affirm the existence of the action: Mineral Indus., Inc. v. George, 44 Misc. 2d 764, 255 N.Y.S.2d 114 (Sup. Ct. 1965). But even on that occasion the claim was actually dismissed for want of proven damage; and its 
claims have been concerning public employees like police officers and firemen. ${ }^{45}$ That the shoe pinches most in these situations is primarily due to the widespread absence of workmen's compensation in these branches of governmental employment. Workmen's compensation statutes, as we sliall see presently, contain specific statutory authorization for indemnity from the tortfeasor, and these claims by cities and other local authorities are therefore really efforts to bridge a statutory gap by resort to the action for loss of services. ${ }^{46}$ That the nature of the employment was public, not private, has occasionally been given as a reason for defeating the claim; ${ }^{47}$ but there are as many cases of similar vintage which have not turned a hair over it, ${ }^{48}$ and others even in the same jurisdiction which, as we shall see, ${ }^{49}$ have sustained similar claims on an alternative theory of subrogation. The record on this point therefore is ambivalent. ${ }^{50}$

authority is further weakened by a superior court having earlier expressed a doubt whether the "hoary rule" still existed in New York. Employers Liab. Assur. Corp. v. Daley, 271 App. Div. 662, 67 N.Y.S.2d 233, 235 (1947). Again, the Third Circuit's sanguine assertion in Jones v. Waterman S.S. Corp., 155 F.2d 992, 1000 (3d Cir. 1946), that Pennsylvania recognized the action ("though we can find no decision directly in point") actually flew in the face of a flatly contrary decision in City of Philadelphia v. Philadelphia Rapid Transit Co., 337 Pa. 1, 10 A.2d 434 (1940).

45 Fringe benefits for city employees have occupied judicial attention for a long time. Besides the 'problem' of reimbursement claims by the city, there was the question whether the employees themselves would have to give credit to the tortfeasor for such disability pay. The collateral source rule was applied in such early cases as Donoghue v. Holyoke St. Ry., 246 Mass. 485, 141 N.E. 278 (1923); Hays v. Morris \& Co., 98 Conn. 603, 119 Atl. 901 (1923) (gratuity); Shea v. Rettie, 287 Mass. 454, 192 N.E. 44 (1934) (as of right). The first of these cases involved a fireman, the last two policemen.

46 An exceptional ease of a fireman being included in the statutory definition of "worker" under a workmen's compensation act, which thus permitted his employer to invoke the statutory indemnity, is Nilsen \& Metropolitan Toronto v. MacGregor [1965] 2 Ont. 732, 52 DI.R.2d 15 (H.C.).

47 Employers' Liab. Assur. Corp. v. Daley, 271 App. Div. 662, 67 N.Y.S.2d 233 (1947), aff'd mem., 297 N.Y. 745, 77 N.E.2d 515 (1948) (volunteer fireman); Hays v. Illinois Terminal Transp. Co., 363 IIl. 397, 2 N.E.2d 309 (1936) (national guardsman not an "einployee" within Illinois' workmen's compensation statute so as to entitle the state of Illinois to statutory subrogation for medical expenses, etc.). The various courts concerned with the case of Standard Oil Co. v. United States (1945-1947) were split on this issue. The district court allowed the claim, holding that a United States serviceman qualified as a "servant" within the statutory cause of action for loss of services. 60 F. Supp. 807 (1945). The Ninth Circuit Court of Appeals disagreed (153 F.2d 958 (1946)), but the precise question was eventually not resolved when the Supreine Court (332 U.S. 301 (1947)) preferred to dismiss the appeal on the different ground that the question was one for federal law which did not recognize such a claim.

48 E.g., City of Youngstown v. Cities Serv. Oil Co., 66 Ohio App. 97, 31 N.E.2d 876 (1940) (fireman).

40 See text accompanying notes 129-132 infra.

50 Prosser, contenting himself with the citation of English cases (and United States $v$. Standard Oil which rests on its own peculiar ground), discerns a "very general refusal" to apply the action to these forms of employment. Prosser, TORTs 962 (3d ed. 1964). 


\section{Recoverable Loss}

No less fascinating has been the division of opinion concerning what losses are compensable by the action for loss of services, assuming it exists at all. As implied by its name a typical recoverable loss would be the extra cost of hiring and training a substitute or the overtime rates paid to other staff. ${ }^{51}$ Also included is consequential loss, such as what the employer might have made over and above the cost of the employee's services, ${ }^{52}$ reduced earnings where the injured servant made up a joint vaudeville act with the employer ${ }^{53}$ or losses incurred from having to interrupt the shooting of a motion picture as the result of injury to a leading actress. ${ }^{54}$ Condemnations of the action as "anomalous" are essentially addressed to claims of this kind, vindicating as they do interests on the part of the employer purely his own and swelling the total accident cost to the defendant. ${ }^{\text {is }}$

Claims for reimbursement of subventions to the injured servant, by contrast, serve the function, not of adding to the defendant's burden, but of redistributing the cost of repairing the servant's injury. Perhaps it is all the more thoughtless for that reason to dismiss categorically, as at least one American court $\mathrm{did}{ }^{56}$ this item of loss as a legitimate head of damage in the action. Denying recovery to a barge owner for the cost he incurred in fulfilling his obligations of "maintenance and cure" for a seaman injured aslore by the tortfeasor, the court advanced the argument that since the plaintiff was contractually bound to render these expenses, they were really "caused" by the contract and not by the defendant's tort; and, that in any event, recovery would be for loss of services and not for expenses incurred in curing the servant.

With the last argument the court certainly ventured beyond its depths.

51 Cf. City of Youngstown v. Cities Serv. Oil Co., 66 Ohio App. 97, 31 N.E.2d 876 (1940), where the claim failed beciuse no such loss had been suffered. Though the city had connnued to pay wages to the disabled firemen, it had not hired any substitutes, apparently because there was no need. Hence it was not out of pocket.

52 Interstate Tel. \& Tel. Co. v. Public Serv. Elec. Co., 89 N.J.L. 26, 90 Atl. 1062 (1914).

53 Mankin v. Scala Theodrome Co., [1947] K.B. $25 \%$.

54 Cf. Darmour Prods. Corp. v. Herbert M. Baruch Corp., 135 Cal. App. 351, 27 P.2d 664 (1933), overruling a general demurrer although the lady was a "servant" only in a legal sense, but sustaining a special demurrer because the allegation that she was not "easily" replaceable was not a sufficiently specific pleading of loss.

55 Seavey, for instance, seemed to have only this aspect in mind when deprecating the action as "out of step" with the modern law, since he dwells consistently on the value of the services. See Seavey, supra note 43 , at 313.

${ }^{56}$ The Federal No. 2, 21 F.2d 313 (2d Cir. 1927). City of Youngstown v. Citles Serv. Oil Co., 66 Ohio App. 97, 31 N.E.2d 876 (1940), appears to haye rẹstẹd op the same reasoning. 
The view is of course tenable that wages paid during disability represent the value of the services to the employee rather than the value of the services lost to the employer. ${ }^{57}$ But this assumes that the action affords recovery only for the value of the lost services-an assumption more appealing to the literal-minded than to those with a teleological concern with purposes and means to achieve desirable ends. For if such wages do not represent the value of lost services, they do represent a loss inasmuch as the employer received no services in return. As already mentioned, the only conceivable debate could be over whether that loss was "caused" by the defendant's tort. Clearly, it was triggered off by it, since "but for" it, the servant would have been able to render the quid pro quo. The objection thus stands exposed as little else than a quibble and, what is more, one that has not unduly perplexed the courts in analogous contexts. In the kindred action by a parent, for example, the claim is typically for the cost of medical treatment imcurred in nursing the injured child, and while this action proceeds on the fiction of the child being a servant, it is neither postulated that the child actually rendered (as distinct from being under a theoretical obligation to render) services nor that the damages recoverable are computed solely on the basis of the value of such services lost. ${ }^{58}$ Likewise, claims by a husband for the medical expenses of his injured wife have been traditionally accommodated as a legitimate aspect of his loss of consortium and servitium. ${ }^{50}$ True, these are all instances of claimants who are under a legal, as distinct from just a contractual, duty of support. But that distinction seems immaterial because the basis of the action for loss of services, regardless of who brings it, has always been a proprietary interest, not

57 Interstate Tel. \& Tel. Co. v. Public Serv. Elec. Co., 86 N.J.L. 26, 90 Atl. 1062 (1914). Almost contemporaneously, and certainly independently, the same argument was propounded by Lord Sumner in The Amerika, [1917] A.C. 38, 61. It has since been espoused by the late Justice Fullagar in two Australian cases (see note 62 infra). A compromise was advocated by Denning and Parker, L. JJ., in Inland Revenue Comm'rs v. Hambrook, [1956] 2 Q.B. 641, 667, 672: As a rule of thumb, the wages paid to the employee were at least prima facie evidence of the employer's loss.

On occasion when it suited them, defendants have not shrunk from contending precisely the opposite-that the loss of the servant's services must be measured exclusively by the master's assessment of their worth (i.e., by the wages the master paid) and any other expenses to which he was put. Rejecting this contention, two cases held that damages were not thus limited and could embrace other consequential loss. Mankin v. Scala Theodrome, [1947] K.B. 257, 262; Bermann v. Occhipinti, [1953] Ont. 1035, [1954] 1 D.L.R. 560 (H.C.).

58 Prosser, Torts 912 (3d ed. 1964); Restatement, Torts $\$$ 703, comment $h$ (1939). See note 74 infra. Based on his duty of support, a parent may evidently claim even when the child is too young to render services and the action for loss of services is thus stricto senstl, unavailable: see note 97 infra.

69 Prosser, Torts 912 (3d ed. 1964); Restatemarnt, Torts \$ 693, comment e (1939). See also Annot., 66 A.L.R. 1189 (1930). 
a duty of support. ${ }^{60}$ Indeed, the weight of authority both in America ${ }^{01}$ and England, ${ }^{\text {,2 }}$ has at least in more recent decisions given unambiguous support to the propriety of including, in an employer's action for loss of services (if such action lies at all), damages measured by expenses incurred for medical treatment of the injured employee.

Much more troublesome is that since the employer's action is independent of and additional to that of the employee, it is calculated to expose the tortfeasor to double liability. Not that it is objectionable in itself for the latter to be hable to more than one person, since his tort may well have caused injury to others beside the immediate accident victim. If such loss is quite separate one from the other, as when the employer has reason to turn down lucrative business by reason of lis employee's disability and thus loses profits, the problem is whether it is not unduly

60 This is not to deny that there is ancient authority for a duty of support of apprentices as of all other members of the familia sharing the same roof. It just happens that there was no organic link between any such duty and the action for loss of services. Nor has it ever been contended that the master's action should be confined to menial services because no corresponding duty of support extended to other kinds of servants: $c f$. Attorney Gen. for New South Wales v. Perpetual Trustee Co., 85 Commw. L.R. 237, 291. (Austl. H.C. 1952). Sone cases (e.g., The Federal No. 2, 21 F.2d 313 (2d Cir. 1927); Fifield Manor v. Finston, 54 Cal. 2d 632, 354 P.2d 1073, 7 Cal. Rptr. 377 (1960)), it is true, emphasize the distinction between legal and contractual duties, but not for any purpose relevant to the action for loss of services. They do so only in turning down the analogy of a parent's or husband's recoupment as relevant to subrogation claims by insurers, etc.

61 Jones v. Waterınan S.S. Corp., 155 F.2d 992 (3d Cir. 1946) (maintenance and cure of seaman under Pennsylvania law); City of Philadelphia v. Philadelphia Rapid Transit Co., 337 Pa. 1, 10 A.2d 434 (1940). The oldest American decision betrayed no doubt. "The master's or parent's right of recovery rests upon the ground that he has been deprived of some service to which he was entitled, or has been put to expense." Woodward v. Wasbburn, 3 Denio 369, 371 (N.Y. Sup. Ct. 1848) (italics added).

62 Bradford Corp. v. Webster, [1920] 2 K.B. 135 (wages during temporary disability and pensions for permanently disabled policemen); Attorney Gen. v. Valle-Jones, [1935] 2 K.B. 209 (pay and hospital treatment of airmen); The King v. Richardson, [1948] Can. Sup. Ct. 57, [1948] 2 D.L.R. 305 (pay and medical expenses of servicenen); Kennshaw v. Latendorff, [1965] 53 West. Weekly R. 672 (Alberta Sup. Ct.) (wages during disability). That such items were recoverable, if the action lay at all in case of an airman, was not questioned in Commonwealth v. Quince, 68 Commw. L.R. 227 (Austl. H.C. 1944), nor in Attorney Gen. for New South Wales v. Perpetual Trustee Co., 85 Conmm. L.R. 237 (Austl. H.C. 1952), except by Fullagar, J. He repudiated recovery of the pension on the grounds that (1) it would involve the tortfeasor in double liability because of the collateral source rule (which Australia, unlike England, continues to apply to pensions: Jones v. Gleeson, 39 Austl. L.J.R. (H.C. 1965), and (2) "the damages must be measured by the value of his services which were lost, not by the incidents of his contract of enployment." 85 Commw. L.R. at 293. The case for medical expenses was different because these were recoverable, if incurred pursuant to a legal duty, as a "natural and probable consequence of the tort." He raised, without answering, the question whether a contractual duty was sufficient, but seven years later had convinced himself that it was (Conmissioner for Rys. (N.S.W.) v. Scott, 102 Commw. I.R. 392, 408). In Scott the defendant conceded the measure of damages, and no final opinion was therefore called for. 
onerous to let liability run that far. This is a problem of "duty" or "proximate cause," if you will, but not one of duplication of damages. If, on the other hand, the employer's claim is for wages and medical expenses, it competes directly with the employee's own possible claim for the same items. Since the damage claims are overlapping, the tortfeasor would be paying twice for the same loss if both claims were sustained.

The English law avoids this untenable disposition by compelling the injured employee, as plaintiff, to give credit to the tortfeasor for wages or pensions from his employer, ${ }^{63}$ insisting on the overriding axiom that damages be strictly limited to indemnity of the net loss sustained. ${ }^{64}$ Claims for medical expenses would be ruled out also because accredited theory requires proof that these, like any other expense for which recovery is sought, must liave been actually incurred..$^{65}$ In the upsliot, then, there is no possibility for duplication of the damages. ${ }^{66}$ Consequently where, as in Australia, the action for loss of services is still broadly available for most types of employment, it is perfectly adequate to the task of accomplishing a shifting of the loss in such a manner that, while the injured employee is not enriched, ${ }^{67}$ the tortfeasor is neither relieved

63 Browning v. War Office, [1963] I Q.B. 750 (C.A.) (pension for U.S. serviceman injured in England reduces tortfeasor's liability). The uncertainty of the law prior to 1963 is reflected in the interesting discourse in Street, Damagees 76-82 (1962). MayNe aNd MCGRECOR, DAMRAGES $\$$ 773-75 (1961), made the wrong guess in coming out against deduction. It is not altogether clear whether the same rule would apply if the employee himself makes an identifiable contribution together with his employer to a scheme, such as to make up the difference between social security benefits and full wages. In McCallum v. G. Madill \& Sons, [1965] No. Ire. L.R. 187 (C.A.), and Smith v. Canadian Pac. Ry., 41 D.L.R.2d 249, 45 West. Weekly R. 170 (Sask. Q.B. 1963), only that part of the pension was deducted that could be attributed to the employer's contribution. So far as the employee's own contribution was concerned, the case was treated as analogous to private insurance. Yet there does not appear to be any realistic distinction between contributory and non-contributory pensions. One is attributable to past payments, the other to past services.

64 The prevailing American ambivalence on this issue was in large measure shared in England until the landmark case of British Transp. Comm'n v. Gourley, [1956] A.C. 185, which held that a defendant was hable only for the plaintiff's net loss of past and future earnings after deduction of income tax, if the award would not be suhject to tax in the recipient's hands. Among other casualties of this rededication to the compensatory principle was the virtual abolition of puritive damages in Rookes v. Barnard, [1964] A.C. 1129. In both respects, American law is now far at odds with the English. See McGregor, Compensation Versus Punishment in Damage Awards, 28 MODERN L. REv. 629 (1965).

O5 Note 72 infra.

66 There is no evidence, however, that the interrelation between the two rules ever affected the sense in which each eventually came to be settled. The death knell of the employer's action tolled in 1956, while the issue concerning the collateral source rule was not finally resolved until 1963.

67 That wages must be deducted from tort damages was authoritatively settled in Australia even before England. Treloar v. Wickam, 105 Commw. L.R. 102 (1961); Graham v. Baker, 106 Commw. L.R. 340 (1961). On the other hand, no credit need be given for 
of any of his burden nor yet exposed to any additional burden. ${ }^{68} \mathrm{If}_{\text {, }}$ however, in England and other jurisdictions following the lead of the English Court of Appeal, the action for loss of services is now proscribed for all but employers of menial servants, the result is to protect the tortfeasor from claims alike by employee and employer so that, in the first and in the last resort, the cost of these disbursements is borne not by him, but by the employer. ${ }^{99}$

In the United States, the perspective is vitally changed by the allbut-universal acceptance of the collateral source rule which permits the injured servant to recover from the tortfeasor in full without any allowance for benefits received from his employer. Wages, pensions and similar emoluments are deemed "collateral" because in a sense they are earned and paid for by the employee, and there is no good reason for diverting the benefits of his thrift to the defendant. ${ }^{70}$ Nor is free medical treatment generally discounted because, according to the dominant American view, recovery is for the value of reasonable medical services, ${ }^{71}$

pensions: Jones v. Gleeson, 39 Austl. L.J.R. 258 (H.C. 1965). Fremoro, Torts 218-19 (3d ed. 1965).

68 Finarnv, Torts $650-51$ (3d ed. 1965). It will be recalled, however, that the question whether action lies for the recovery of such expenses is still open (note 62 sitpra). The astounding decision regarding pensions (note 67 supra) may suggest an implicitly negative answer.

69 The last desperate attempt by an employer to shift the loss to the tortfeasor, on a theory of unjust enrichment, failed in Receiver for Metropolitan Police Dist. v. Croydon Corp., [1957] 2 Q.B. 154 (C.A.).

${ }^{70}$ Almost uniformly, American courts apply the collateral source rule to wages and pensions received by the injured person from his employer. Restateasent, Torts \& 920, comment $e$ (1939). See, on wages, Annot., 7 A.L.R. 3d 516 (1966) and, on pensions, Annot., 75 A.L.R.2d 885 (1961) (personal injury) and Annot., 81 A.L.R.2d 948 (1962) (wrongful death). The number of jurisdictions maintaining the contrary rule is small, shrinking and tending to curtail the practice. Ohio apparently joined the ranks of the majority in Rigney v. Cincinnati St. Ry., 99 Ohio App. 105, 131 N.E.2d 413 (1954). New York will now reduce recovery only by the amount of gratritous benefits, but not when the benefits were received under a sickness or disability plan incidental to a collective bargaining agreement. Klein v. United States, 339 F.2d 512 (2d Cir. 1964). Paradoxically, it is precisely to gratuities only that the remaining minority states will apply the collateral source rule. Bachelder v. Morgan, 179 Ala. 339, 60 So. 815 (1912); Moon v. St. Louis Transit Co., 247 Mo. 227, 152 S.W. 303 (1912); Feeley v. United States, 337 F.2d 924 (3d Cir. 1964) (Pennsylvania law).

71 Restatemant, Torts § 924 (1939). Thus the great majority of jurisdictions allow recovery of the reasonable value of gratuitous medical care or services rendered either by a third party or a spouse. Only a few disallow it on the "English" view, insisting on proof of expenses actually incurred. Most of the minority cases are probably now unrehable, except in New York (Drinkwater v. Dinsmore, 80 N.Y. 390, 393 (1880); Coyne v. Campbell, 11 N.Y.2d 372, 183 N.E.2d 891 (1962)), and probably Pennsylvania (see Feeley v. United States, 337 F.2d 924 (2d Cir. 1964)). The cases are collected in Annot., 90 A.L.R.2d 1323 (1963). Nor has the distinction drawn by Restatemane, TORTs § 924, comment $f$ (1939), against recovery for the value of gratuitous medical services supplied by state supported or other public charities, struck any responsive chord. See Hudson v. Lazarus, 217 F.2d 344 
not (as in English law) for expenses reasonably incurred. ${ }^{72}$ Against this background, an independent claim by the employer, not geared to the employee's, would be apt to result in double liability for the tortfeasor.

Strangely, few courts have evinced much understanding of this troublesome aspect. There are some scattered expressions of generalized concern over "splitting" causes of action, but no more than two or three decisions actually aver double liability as a ground for denying recovery. ${ }^{73}$ This is the more remarkable because courts lave been so obviously casting around for just any plausible reason to justify their ruling agamst these claims. All the same, it would seem to constitute a well-nigh fatal obstacle to the use of this action as a means for reimbursing the employer. True, in the soniewliat analogous cases of parent and liusband, the problem lias not posed an insuperable challenge to judicial ingenuity, ${ }^{74}$ but

(D.C. Cir. 1954), not following Di Leo v. Dolinsky, 129 Conn. 203, 27 A.2d 126 (1942). See Annot., 68 A.L.R.2d 876 (1959).

72 English law requires that, with respect to treatment received, the claimant must prove the cost he has incurred, i.e. either that he has paid or that he has at least incurred a legal obligation to pay. Mayare \& MCGRegor, Dansages \$§ 761-62 (1961); StreET, DaMAGES, 82-85 (1962); Blundell v. Musgrave, 96 Commw. L.R. 73 (Austl. H.C. 1956) (discussed infra, note 207). Apparently, however, a statute-barred debt will still qualify. Allen v. Waters \& Co., [1935] 1 K.B. 200 (C.A.). (It also does in Massachusetts Sibley v. Nason, 196 Mass. 125, 81 N.E. 887 (1907).) But free treatment or nursing services are ruled out, whether rendered from charity, familial obligation, or as a social security benefit. Canadian and Australian decisions are cited in Flensrng, Torts 20 n.3 (3d ed. 1965). An older, but still viable Canadian decision disallowing recovery for medical services rendered pursuant to a prepaid medical plan is Taylor v. Turner, 2 West. Weekly R. 490 (Sup. Ct. of Alberta, 1925).

73 Clearest is United States v. Klein, 153 F.2d 55 (9th Cir. 1946) where the contrary English decision in Attorney Gen. v. Valle-Jones [1935] 2 K.B. 209 was expressly distinguished on the ground that under English, unlike Iowa, law the Civilian Conservation Corps enrollee would not have been able to recover these expenses in his own right, thus disposing of the problem of double liability for the tortfeasor. Besides, the United States Employees' Compensation Act (on the model of workmen's compensation) furnished an exclusive remedy for the employer in the right of subrogation it conferred on him. $153 \mathrm{~F} .2 \mathrm{~d}$ at $58-59$.

In Chelsea Moving \& Trucking Co. v. Ross Towboat Co., 280 Mass. 282, 182 N.E. 477 (1932), the court coyly played with the notion that all damages from one cause of action should be disposed of in one proceeding. Rather than being concerned with the familiar "sphitting the cause of action" foible, the court worried about double liability. Why otherwise be at pains to establish that the injured person would not have to give credit to the tortfeasor for the wages received from his employer? This also appears to be at the bottom of the same labored reference to the policy against splitting causes of actions in City of Philadelphia v. Philadelphia Rapid Transit Co., 337 Pa. 1, 10 A.2d 434, 435 (1940), where the court was content to tolerate a claim based on a theory of subrogation which avoids double liability.

74 Fairly clear lines of demarcation as to recoverable losses have been drawn so as to avoid duplication of damages. Thus: (1) In the case of an injured child, damages for loss of his prospective earnings during minority belong to the parent; after majority, to the child. Damages for medical expenses already incurred belong to the parent (unless the child has paid or otherwise become responsible for them); for future treatment; to the child. 
these have been somewhat easier to handle, first because the problem is there primarily encountered only with respect to medical expenses and, secondly, because husband and wife, no less than parent and child, can be treated procedurally as a common unit more easily than employer and employee. ${ }^{75}$ Reimbursement for the employer is more expediently accomphished through other means to which we now turn.

\section{B. Subrogation}

The theory of subrogation offers a neat and well-tried device for at once vindicating the primciple of indemnity and reallocating the burden of the loss to the tortfeasor without, however, involving him in multiple hability. The mechanisin is simple enough: The subrogee, having indemnified the injured person for the whole or part of his loss, is pro tanto substituted to the latter's (the subrogor's) rights against the tortfeasor. The tortfeasor in turn is precluded from pleading that the injured person has already been indemnified, because thus to reduce his liability would prevent reimbursing the subrogee and shifting the loss to the defendant. Essential to the success of the maneuver is therefore strictest observance of the collateral source rule ${ }^{76}$ as well as the refusal to lend any countenance whatsoever to the argument that the injured person has in reality suffered no (net) "loss." At the same time, just because the subrogee has no independent claim against the tortfeasor, the latter does not run the risk of being mulcted more than once. Generally speaking he acquits

There is scant support for the view expressed in comment $h$ of section 703 of the Restatement of Torts that the parent may recover for future medical treatment during the child's minority, if under a duty to furnish such support. (2) A husband is certainly entitled to recover all past expenses, and probably also all future expenses, of treating his injured wife, primarily because it would be he who would also incur them. Generally, the wife may herself recover on proof that she incurred them, but some courts also allow her to recover on the ground merely that she could make herself hable for them. The cases are collected in Annot., 32 A.L.R.2d 1069 (1953) (parent-child) and Annot., 66 A.L.R. 1189 (1930) (husband-wife).

Even on matters where there is no uniform rule, the question who recovers what generally receives a clear-cut answer in any jurisdiction. As regards past medical expenses the dividing line is generally drawn on the basis of who incurred the cost. This is in marked variance with the presently prevailing practice in cases of employer-employee.

75 In cases of husband and wife, for example, a common (though by no means uniform) practice is to award medical expenses to whoever of the two claims them. Payment to one would presumably "merge" the claim of the other. While there is some precedent for dismissing a wife's claim on the ground that the husband would have been the proper claimant (e.g., Dwyer v. Jackson Co., 20 Wis. $2 \mathrm{~d} 318,121$ N.W.2d 881 (1963), there is none for allowing a second recovery merely because payment was in the first instance made to the wrong spouse.

${ }^{76}$ It has even been claimed that the primary purpose of the collateral source rule is "to implement the insurance company's right of subrogation." Consolidated Freightways, Inc. v. Moore, 38 Wash. 2d 427, 430, 229 P.2d 882, 884 (1951). 
himself by paying either the subrogor or subrogee. If he pays the former, the latter may no longer look to him, ${ }^{77}$ but is relegated to recourse against the subrogor himself.

The most familiar instance of subrogation is found in property and other types of indemnity insurance. Although its primary purpose is to vindicate the principle that the assured shall be no more than indemnified for his actual loss, its by-product is to shift the loss from the insurer to the tortfeasor-so much so that it has often been praised as an adjunct to the assumed aim of tort law: punishing the guilty. ${ }^{78}$

Traditionally, however, subrogation is not considered an incident of insurance agaimst personal injury. ${ }^{79}$ To reexamine in any great depth the reason for this limitation would prove an unprofitable diversion. ${ }^{80}$ Suffice it here to distill from among the many arguments as the most important that such lunip-sum assurances bear no necessary relationship to the actual loss and thus cannot be considered indemnity contracts, that the insured sliould be entitled to the benefit of the premiums he has paid as a reward for his thrift and foresight, and that tort damages rarely, if ever, indemnify a plaintiff completely for personal injuries, especially when his attorney's fees will devour the hon's share of the award. Admittedly, these arguments are not beyond challenge. The sum assured in life and accident policies are not that much different from "agreed value" clauses in property insurance: ${ }^{81}$ the former as much as the latter generally represent a genuine estimate, at least of the minimum ${ }^{82}$ material

77 The tortfeasor remains liable to the insurer only if, with knowledge of the latter's right of subrogation and without his consent, he settles with the insured. Calvert Fire Ins. Co. v. James, 236 S.C. 431, 114 S.E.2d 832 (1960); 29A Axr. Jor. Insurance § 1733 (1960).

78 See especially Horn, Subrogation In Insurance Theory and Practice (1964), an ardent and rather credulous champion of this viewpoint. Not being a lawyer, the author tends to ascribe more than their due importance to scattered judicial pronouncements to this effect.

793 Appleman, Insuratice Law and Practice $\$ 1675$ (1941); 8 Couch, Cyctopedia of INSURANCE LAW § 1997 (1931); RICHARDS, Insuraitce § 184 (5th ed. 1952); VANCE, Insurance $\$ 134$ (3d ed. 1951). Leading cases are Aetna Life Ins. Co. v. J. B. Parker \& Co., 97 Tex. Civ. App. 521, 72 S.W.2d 621 (1902); Gatzweiler v. Milwaukee Elec. Ry. \& Iight Co., 136 Wis. 34, 116 N.W. 633 (1908); Mercer Cas. Co. v. Perlman, 62 Ohio App. 133, 23 N.E.2d 502 (1939).

80 It would be supererogatory to retread the ground so thoroughly explored by Kimball \& Davis, The Extentsion of Insurance Subrogation, 60 MrcH. L. REv. 841 (1962). The authors were concerned with investigating what kind of insurance contracts permit subrogation, legal or conventional. Legal subrogation arises by force of law, conventional from specific stipulation in the insurance contract.

81 See especially Omori, The Valued Policy, in INTERnationales Versichingungsrecht (FESTSCHRIFT FÜ̈ A. EHRENZWEIG) 185-96 (1955), who questions the very notion of "objective" indemnity as the basis of property insurance in order to find a common link between life and so-called indemnity insurance.

82 The principle of indemnity is limited to a maximum, not a minimum. Hence, neither identity of loss nor quantitative equivalence between loss and claimed reimbursement 
loss likely to be sustained. ${ }^{83}$ Then again, while life insurance of the endowment type (as distinct from short "term") bears substantial saving and investment features this is not at all true of accident insurance. True, the insured has himself paid for his insurance benefits, but he had the advantage of being covered against all accidents during the term of the policy. Since the odds are quite overwhelmingly on the side of nontortious accidents, there is little merit in the assertion that subrogation would in effect allow the tortfeasor unfairly to divert the plaintiff's expenditure to his own benefit. ${ }^{84}$ For the same reason, it is but an idle fancy to pretend that the insured desired to bargain for double recovery (and should be free to do so). What was more probably in the insured's mind was to hedge himself against loss rather than to gamble for a windfall.

Nor can one leave this subject without adverting to the argument that insurers lack all claim to reimbursement because they deliberately assumed the loss as a business risk. The crux of the objection here cannot be to the fact that the insurer was bound to incur the outlay, because the common law's uncharitable bias against volunteers has in actual fact tended to disqualify all voluntary benefactors and to support only claimants who were, at the very least, under some legal obligation to confer the benefit on the injury victim. In this connection, a contractual obligation (such as an employer's) has generally been considered suffcient, even if not as strong as that of an independently legal duty of support like a husband's or parent's. The real objection against insurers is therefore, not that they bound themselves to pay, but that they assumed the risk. Yet that the law has traditionally permitted subrogation for certain kinds of insurance indicates that even this cannot be the parainount obstacle.

To say, therefore, that an insurer rather than the tortfeasor had the primary duty to ineet the expense is to state a conclusion, not a reason: In short, it is the very matter in issue. Nor is it sufficient to state that the insurer assumed the risk. The question is not whether he assumed it, but whether he assumed it without recourse; and that would seem to

are essential conditions for subrogation. See Geneva Constr. Co. v. Martin Transfer \& Storage Co., 4 IIl. 2d 273, 281, 122 N.E.2d 540, 545 (1954).

83 There can of course be no cloubt at all about the indemnitory nature of insurance, increasingly more common in England and Europe, covering the difference between social security benefits and pre-accident wages. Such a policy was in issue in $\mathrm{McCa}$ llum v. G. Madill \& Sons, Ltd., [1965] No. Ire. L.R. 187 (C.A.), which held that the injured plaintiff need not give the tortfeasor credit for $1 / 3$ in view of his own contributions to the scheme. Yet, although the matter has not been tested, there is every reason to think that such policies would be treated as non-subrogatory just like medical payment clauses, for no other reason than that they are concerned with personal injuries. See note 86 infra.

842 HARPER \& JAMIES, TORTS 1351-54 (1956). See also Kimball \& Davis, supra note 80, at 851 . 
depend in the last resort on one's philosophy of loss allocation rather than on any verbal formulation. All the same, it is now well settled that there is no subrogation and in combination with the collateral source rule which umversally prevails in relation to all kinds of private insurance, ${ }^{85}$ the assured may thus bargain for double recovery.

\section{Accident and Medical Benefit Insurance}

The importance of accident and medical insurance in relation to the whole picture of loss allocation is far from trifling. Life insurance, long the badge of middle-class status, is becoming ever more prevalent ainong all sections of the community. Especially group insurance of the "term" variety is apt to play a particularly prominent role, from a volume standpoint, in compensating fatal accidents. Again, accident insurance used to be fairly rare until the rash of popularity for comprehensive or package automobile policies which nowadays almost always include inedical payment coverage for passengers and which also serve in many jurisdictions the secondary function of gap-filler for "guest statute" immunity of negligent drivers. ${ }^{86}$ Last, and perhaps most important of all, is that all medical insurance and health plans, including probably even inedical payments coverage in automobile insurance, fall under the same regime - that is, the injured person may invoke the collateral source rule $e^{87}$

85 No principle is more uniformly and universally recognized throughout the world. American case law on personal insurance (personal injuries and death) is collected in Annot., 95 A.L.R. 575 (1935), supplenenting 18 A.L.R. 678 (1922); on property insurance, in Annot., 81 A.L.R. 320 (1932). See also Maxweil, Collateral Source Rule in the American Law of Damages, 46 Mins. L. Rev. 669, 672-79 (1962). English law, otherwise firmly committed to the compensatory principle, also allows an exception for private insurance. Bradburn v. Great Western Ry, L. R. $10 \mathrm{Ex.} 1$ (1875). In the case of wrongful death actions, however, it required statutory intervention to overcome the mean judicial tradition of requiring hiterally all benefits accruing to dependents from the death to be brought into account. Fatal Accidents Act, 1959. Some Commonwealth legislation now excludes consideration of any gain. FLEMTNG, TORIS 637 (3d ed. 1965).

86 That the plaintiff's own medical payments coverage is treated as collateral is arrestingly illustrated by Severson v. Milwaukee Auto. Ins. Co., 265 Wis. 488, 61 N.W.2d 872 (1953), where it was invoked against an insurer liable to his insured under two clauses of the same policy: the medical payments clause and an uninsured motorist clause. The first was treated as collateral to the second, since the latter represented the liability of another party, the uninsured defendant. It is easier to abide this solution where the same company just happened to insure both plaintiff and defendant, as in Sonnier v. State Farm Mut. Auto Ins. Co., 179 So. 2d 467 (La. Ct. App. 1965). The great weight of authority, however, gives the defendant credit for payments to the plaintiff under the defendant's own medical insurance policy. Dodds v. Bucknum, 214 Cal. App. 2d 206, 29 Cal. Rptr. 393 (1963); Turner v. Mannon, 236 Cal. App. 2d 134, 45 Cal. Rptr. 831 (1965); Adams v. Turner, 238 F. Supp. 643 (D.C. 1965); Gowens v. Morgan \& Sons Poultry Co., 238 F. Supp. 339 (M.D.N.C. 1965); Moore v. Leggette, 24 App. Div. 2d 891, 264 N.Y.S.2d 765 (1965).

87 In California the decision in Purcell v. Goldberg, 34 Cal. App. 2d 344, 93 P.2d 578 
and the insurer has no right of subrogation despite the fact that they are quite demonstrably indemnitory in character and purpose. ${ }^{88}$ As a result, Blue Cross, California Plrysicians' Service, Kaiser Foundation and similar plans which nowadays take care of the overwhelming bite of the inedical bills also thereby contribute proportionately to that distortion $^{89}$ whereby a sizeable number of accident victims receive multiple conipensation while so many others go un- or under-compensated.

Nor is there any genuine prospect for imminent cliange in this respect. Although contractual subrogation clauses ("conventional" as distinct from "legal" subrogation) have been sanctioned on a few occasions by the courts, ${ }^{90}$ there is presently no disposition to exploit this device

(1939), placed beyond doubt that medical benefits supplied, or paid for, under a health plan do not reduce tort damages. All seventeen jurisdictions confronted with the question have so held, including even New York which adheres to the general principle that there can be claim only for expenses incurred. Healy v. Rennert, 9 N.Y.2d 202, 173 N.E.2d 777 (1961). The cases up to 1950 are collected in Annot., 13 A.L.R.2d 355 (1950).

88 The leading case is Michigan Hosp. Serv. v. Sharpe, 339 Mich. 357, 63 N.W.2d 638 (1954). See also Publix Cab Co. v. Colorado Nat'1 Bank, 139 Colo. 205, 338 P.2d 702 (1959). A reductio ad absurdiım is Severson v. Milwaukee Auto. Ins. Co., 265 Wis. 488, 61 N.W.2d 872 (1953), which allowed the injured person to recover for the same damage cumulatively under liability and medical payments coverage of the same policy. In this connection, no distinction is drawn between insurance and medical service plans, although it would be somewhat easier to ascribe to the latter a primary obligation, as was done in the Sharpe case. But primary even vis-a-vis the tortfeasor? The conclusion is trenchantly criticized by Kimball \& Davis, subra note 80 , at 860 . American courts tend to make their classification "for the whole line, despite the deviant contracts." Thus all personal insurance is lumped together, including individual indemnity coverage, witl subrogation being demied to all. This blunt technique is not allowed in all other countries. The Scandinavian insurance laws specifically save medical coverage from the exclusion of subrogation for hife and accident policies. See note 243 infra. German law, though more obscurely, appears to maintain the same position. See Kimball \& Davis, supra note 80, at 853-54. The Swiss Supreme Court has also consistently taken the same line, in strong opposition to the literature. See 1 OFIINGer, SchweIzerisches HAFTPFIICHTRECHT 340-41 (2d ed. 1958).

89 See text accompanying note 9 supra.

80 The leading authority is Michigan Medical Serv. v. Sharpe, 339 Mich. 574, 64 N.W.2d 713 (1954) (Blue Shield), which is the more significant because in a companion case (see note 88 supra) subrogation was demied in the absence of any express subrogation clause. Other decisions giving effect to conventional subrogation clauses are Smith v. Motor Club of America Ins. Co., 56 N.J. Super. 203, 152 A.2d 369 (1959); Travelers Ins. Co. v. Lutz, 3 Ohio Misc. 144, 210 N.E.2d 755 (1964); and Appeal of Maak, 30 Misc. 2d 610, 222 N.Y.S.2d 845 (Sup. Ct. 1961), all involving medical payments insurance. The last case based itself on the more general ground that all such insurance is indemnitory in character (and might thus perhaps support even legal subrogation?).

The most potent argument favoring the validity of conventional subrogation is that the indemnitory character of medical payments insurance is placed beyond argument by an express subrogation clause which revcals a manifest intent that the obligor be only committed to indemnify for net loss incurred. Nor is there any public policy mibtating against such an arrangement, since it could only purport to affect indemnitor and indemnitee. Note that I am not lere touching upon the possibility of giving the tortfeasor the benefit of the insurance, but only with whether the injured person should have double recovery. 
systematically.$^{01}$ This solicitude is due primarily to the fear among these organizations of hurting their customer appeal, coupled with the realization that only very modest savings would ensue..$^{22}$ Besides, there is also much formidable authority against "conventional" subrogation.

Prominent is the California Supreme Court decision in Fifield Manor v. Finston dismissing an action to recover the cost of essential medical care rendered pursuant to a life-care contract to a person negligently injured by the defendant. ${ }^{93}$ Significantly, the claim failed on each of two distinct theories. First, as a direct claim, the analogy of the statutory action of a parent or husband (for loss of services) was distinguished on the familiar, thougl nonetheless tiresome, ground that here there was only a contractual rather than a legal duty of support. ${ }^{.4}$ This also ruled out the more generalized principle of restitution for medical expenses incurred pursuant to a legal duty towards a tort victim ${ }^{95}$ - a principle

\footnotetext{
81 As advocated by Katz, Automobile Medical Payments Coverage-A Changing Concept?, 28 Ins. Counser J. 276 (1961).

82 It has been unofficially estimated that systematic subrogation recoveries would not reduce the monthly contribution to the Kaiser Health Plan by more than four cents. This throws some incidental light on how negligible is the proportionate cost of tort-proved accidents, and should give pause to those who argue that reducing the tortfeasor's liability by the benefits the plaintiff has received from an accident policy would unfairly divert to him the plaintiff's own expenditures. Accident policies, still more health plans, confer a hedge against all accident and illness, whose value is great enougli without regard to such as were tort-induced. The insured las therefore received his quid pro quo in every practical sense, even if he were demed double recovery.

9354 Cal. 2d 632, 354 P.2d 1073, 7 Cal. Rptr. 377 (1960).

94 The adumbrated distinction between a legally imposed and a contractually undertaken duty of support is of course by no means the bramchild of California jurisprudence. Like a deus ex machina it has been haunting many a legal stage, in general true to its promise of baulking further inquiry as if it embodied a self-evident truth. It is, of course, easy enougls to understand the near-unanimity with which entirely voluntary support is disqualifed by most legal systenis. See, e.g., City of Richmond v. Hanes, 203 Va. 102, 122 S.E.2d 895 (1961); Mineral Indus., Inc. v. George, 44 Misc. 2d 744, 255 N.Y.S.2d 114 (Sup. Ct. 1965); The Amerika, [1917] A.C. 38. Thougb there is indeed nuch to be said for "Good Samaritans," it does not need a mind steeped in fundamentalist individualism to dispute their claim to indulge philanthropy at somebody else's expense. However that may be, disbursements pursuant to contract are made under legal compulsion just like support required by statute or common law; once the volunteer-or, if you will, officious intermeddler-is exeluded, the elaim to indemnity seems to be no less strong in the first case than in the second. The only possibly relevant difference between them lies not in the source of the respective duties, but in the fact that the contractual provider has in a sense received a quid pro quo or, what amounts to the same thing, that the beneficiary paid for the benefit. Yet this argument carries little weight when one considers that the payer enjoyed coverage also, and principally against nontortious injuries. If that argument is insufficient to support double recovery, it is also insufficient to defeat recoupment.

85 Although there is no apparent mention of it in the American Law Institute's Restatement of Restitution, this principle of restitution has ancient roots. See the cases cited in notes 96-97 infra. As already noted, it enjoyed the support of Fullagar, J., in the Australian High Court cases; but lie, unlike the California court, would have extended it to payments pursuant to a contractual duty. See note 62 supra.
} 
which has occasionally supported claims outside the conventional purview of the action for loss of services, like those of a wife for the cost of medical care expended on her husband, ${ }^{98}$ or of a parent for a child too young to render services. ${ }^{97}$

Nor did the claim fare any better on the alternative theory of subrogation, which was dismissed on the hollow ground that it would have violated the rule against assignability of tort claims for personal injury. That rule was, and perhaps still is, sensible enough as a safeguard against trafficking in litigation: the ancient evil of maintenance. ${ }^{98}$ Insurers, however, play a socially accredited role in the business of absorbing tort losses, and it is mechanical reasoning at best which would invoke against them a rule with an entirely foreign rationale. ${ }^{99}$ Accordingly in England where the policy against assignments of tort causes of action is still as strong as anywhere, the law has yet proved itself flexible enough to permit express assignment in favor of insurers. ${ }^{100}$ American courts might well draw some courage from the fact that the related policy against maintenance and champerty did not prevent their predecessors from engrafting an exception in favor of contingent fees. In the present con-

96 Follansbee v. Benzenberg, 122 Cal. App. 2d 466, 265 P.2d 183 (1954). A wife has no cause of action in Cahfornia for the loss of her husband's services. Deshotel v. Atchison T. \& S.F. Ry., 50 Cal. 2d 664, 328 P.2d 449 (19.58), expressly distinguishing Follansbec. A husband does have an action for loss of services in California-under section 427 of the Code of Civil Procedure-limited however to material loss. West v. City of San Diego, 54 Cal. 2d 469, 353 P.2d 929, 6 Cal. Rptr. 289 (1960) (no damages for sexual incapacity). Such material damage may consist in "Ioss of services of his said wife, moneys expended and indebtedness incurred by reason of such injury ... ." Car. Code of Crv. Proc. § 427 (emphasis added). See also Walling v. Kimball, 17 Cal. 2d 364, 110 P.2d 58 (1941).

97 Hall v. Hollander, 4 B. \& C. 660 , 107 E.R. 1206 (1825); Dennis v. Clark, 56 Mass. (2 Cush.) 347, 48 Am. Dec. 671 (1848).

88 See Annot., 40 A.L.R.2d 500 (1955). Since the prohibition was linked to survival at conmon law, personal injury claims in inany jurisdictions came to be leld assignable once statutes had introduced survival. Other states luave not drawn this conclusion, either on the general ground that the rule against assignnent was too firmly entrenched to be thus swept away by a sidewind or because the survival statute expressly reserved the issue of assignability, as in California. ("Nothing in this section shall be construed as making assignable things in action ... not to have been assignable prior [hereto]." CaI. Prov. CODE \& 573.)

${ }^{89}$ So mucli for conventional or express subrogation. Even less relevance has any surviving rule against assignability to legal subrogation. Therefore, to argue that because personal injury claims are not assignable, there is no legal subrogation for medical expenses, identifies not only quite illegitimateiy two quite separate claims, but also subrogation with assignment. Cf. Kimball \& Davis, supra note 80, at 858.

100 King v. Victoria Ins. Co., [1896] A.C. 250 (P.C.). This was admittedly an assignment in favor of an indemnity insurer who would have been entitled to subrogation. But the English rule acts against assignments of all tort claims (not oniy personal mjury claims). The court, however, did not give the slightest hint that its ruling, allowing the assignee to sue in his own name, was confined to assignees who would in any event have been able to sue as subrogees in the nanie of their assignors. 
text, however, American case law remains, almost without exception, ${ }^{101}$ hopelessly locked in a split of authority turning solely on whether general assignability prevails in the particular jurisdiction or not. ${ }^{102}$ The conclusion on this issue is usually matched by a corresponding difference of view on whether subrogation is desirable as a matter of policy. Some courts fancy a specter of multiple subrogation claims, complicating the business of settlement as well as "promoting suits and interpleaders"; while others regard the very possibility of multiple coverage a good enough reason for permitting subrogation to prevent the plaintiff from profiting by his accident. The former declare that subrogation will make no difference to the cost of insurance; the latter that it will bring premiums down. Honors are thus about evenly divided.

\section{Workmen's Compensation}

The principal inroad on the exclusion of subrogation from the area of personal injuries is the riglit of indemnity that almost all workmen's compensation statutes have expressly conferred on the employer or his insurance carrier. ${ }^{104}$ Workmen's compensation, where applicable, is the employee's exclusive remedy against the employer. Yet, far from wishing to exempt third parties from tort liability, it actively promotes eventual shifting of the loss to the tortfeasor in one of three ways: The employer, having paid compensation to an employee, may recover the amount so expended from the tortfeasor by (1) bringing an action against him directly, (2) joining as a party plaintiff or intervening in an action

101 A notable exception is Remsen v. Midway Liquors, Inc., 30 Ill. App. 2d 132, 174 N.E.2d 7 (1961), concerning a trust agreement under an uninsured motorist endorsement which entitled the insurer to the proceeds of any settlement or judgment to the extent of any payments to the assured. This arrangement was held to partake of the nature of subrogation rather than assignment, and therefore to be outside the legal policy against assignments of tort claims. The court invoked the analogy of subrogation for workmen's compensation-see note 112 infra-as indicative of Mlinois policy favoring subrogation.

102 Thus the three cases cited in note 90 supra, endorsing subrogation clauses, are from jurisdictions permitting assignability: Michigan, New Jersey and Ohio. Conversely, California and Missouri disallowed them precisely as a corollary of nonassignability. The Missouri decision, aligning itself with California, is Travelers Indem. Co. v. Chumbley, 394 S.W.2d 418 (Mo. App. 1965). Cf. City of Richmond v. Hanes, 203 Va. 102, 122 S.E.2d 895, 900 (1961). See also Kimball \& Davis, Extension of Insurance Subrogation, $60 \mathrm{MICH}$. L. REv. 841,867 (1962).

103 This extravaganza stems from Travelers Indem. Co. v. Chumbley, supra note 102, at 425 . A subsidiary argument occasionally encountered is the policy against splitting causes of action. But this is surely mere makeweight since it is not an obstacle to subrogation in property damage claims. On the other side, the contention has been pressed that the Insurance Commissioner, by not banning the subrogation clause, has impliedly conferred on it legislative sanction.

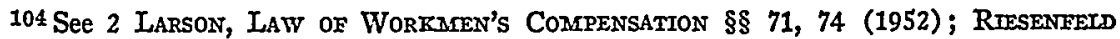
\& MaXWetr, Modern Soctar LegtsLatron 395-97 (1950). 
brought by the employee, or (3) allowing the employee to prosecute the action himself and subsequently applying for a lien against the amount of the employee's judgment. ${ }^{105}$ How strongly, by the way, this policy is complemented by an overriding concern against double recovery by the injured workman is implicit in decisions which insist that the employee's tort damages be reduced by the amount of workmen's compensation he received in those rare cases where his employer has forfeited his clain to reimbursement because of personal or vicarious negligence. ${ }^{100}$

The importance of the general riglit of indemnity under workinen's compensation cannot be overestimated since it controls the adjustment of accident losses for virtually all work injuries. For the sake of proper perspective, therefore, it must be emphasized that the controversial common law position of an employer's right to reimbursement is principally concerned only with those relatively rarer situations outside the ambit of workmen's compensation-in other words, job accidents by employees not covered by workmen's compensation or accidents of employees when off work. The absence from a few workmen's compensation statutes of any provision for indemnity has posed a vexing problem on whicl courts have been sharply divided. Generally, such claims for recoupment have been advanced on the analogy of the master's action for loss of services or the broader restitutionary theory of a right to indemnity for expenses necessarily incurred. Indeed, some of the more modern American dicta for or against the action for loss of services are encountered in this context. ${ }^{107}$ Not infrequently negative decisions are tinctured by consid-

105 E.g., CAI. LAB. CodE $\S \S 3852,3853,3856$.

100 Witt v. Jackson, 57 Cal. 2d 57, 73, 366 P.2d 641, 650, 17 Cal. Rptr. 369, 378 (1961) ; Lovette v. Lloyd, 236 N.C. 633, 669, 73 S.E.2d 886, 892 (1953). In general, workmen's compensation acts do not advert to the effect of negligence by the employer on his statutory right of indemnity. Most courts have inferred from the statutory silence a legislative intent not to prejudice that right. Royal Indem. Co. v. Southern Cal. Petroleum Corp., 67 N.M. 137, 143, 353 P.2d 358, 363 (1960), and decisions from many jurisdictions there cited. California, in the above-cited Witt case, joined company with Pennsylvania and North Carolina in denying such reimbursement to a negligent employer. This entails in effect a sharing of the accident cost between employer and tortfeasor, all the more acceptable since the introduction of contribution between tortfeasors in California in 1957.

In jurisdictions with comparative negligence laws the last word may depend on the relevant statutory language. English law, for example, used to accord with California in deeming the employer's own neghigence as prejudicial as his employee's and accordingly barred recoupment (Cory \& Sons, Itd. v. France, Fenwick \& Co., [1911] 1 K.B. 114 (C.A.)). In the Australian state of Victoria it has been held that this position was not changed by the introduction of apportionment of loss, since the statute bad inadvertently failed to extend the new régime (of merely reducing recovery) to the case of an employer's negligence as it had taken the trouble to do in case of the employ'ee's negligence. Adams v. State Rivers Conini'n, [1960] Vict. L.R. 542.

107 E.g., Crab Orchard Improvement Co. v. Chesapeake \& Ohio Ry., 115 F.2d 277, 283 (4th $\mathrm{Cir} .1940$ ). 
erations of legislative history peculiar to the particular workmen's compensation act, ${ }^{108}$ and must therefore be discounted as a source for wider generalizations. An adverse inference as to legislative intent is of course also open from the very omission of any statutory mandate for subrogation because it represents such a glaring departure from the general pattern. One reason that might have prompted a deliberate omission is that the particular state has a monopoly of workmen's compensation insurance which bases its tariffs on a year-to-year rating experience and, being non-profit, would have hittle interest in subrogation recoveries. ${ }^{100}$ The cases however do not mention any such mundane considerations but content themselves with the argument that workmen's compensation is really akin to accident insurance which traditionally demes subrogation. ${ }^{110}$ The analogy is pressed that payments to the injured workmen are fixed by an arbitrary scale, without regard to the detriment actually suffered, and that in any event there is the same difficulty about appraising the cost of lruman suffering or the value of life. ${ }^{111}$

These arguments are distinguished only by their superficiality and have accordingly failed to command widespread support. ${ }^{112}$ That the purpose of workmen's compensation is to indemnify the worker for his pecuniary loss is all the more obvious considering that lis average weekly earnings are commonly the basis for computing his award. It is irrelevant that compensation furnishes less than a full indemnity since subrogation has never been denied in cases of indemnity insurance policies with a fixed ceiling where the sum payable miglit accordingly well be less, but can never be more, than the actual loss. Nor is it relevant that the measure of damages in a tort action by the injured employee would not be the same as that in an indemnity claim by the employer (since the former would include other heads of damage like pain and suffering), for that is a

108 E.g., Crab Orchard Improvement Co. v. Chesapeake \& Ohio Ry., supra note 107. The West Virginia statute had previously been construed to permit employees to retain both compensation and tort damages. While this did not compel a decision against subrogation, it was a strong pointer for a federal court. To allow the claim would have exposed the tortfeasor to the risk of double liability, and the principal reason for subrogation-to prevent double recovery-did not apparently conform to the Jocal policy.

109 Unlike private insurance carriers which operate on a three-year cycle which offers greater opportunities for returming the benefit of subrogation recoveries to the insured in the form of lower premiums or passing it to stockholders as profit.

110 See note 79 supra.

111 See, e.g., Crab Orchard Improvement Co. v. Chesapeake \& Ohio Ry., 115 F.2d 277 (4th Cir. 1940). This approach was also advocated in a Note, 38 HARv. L. REv. 971 (1925). 112 The most categorical repudiation on record is Geneva Constr. Co. v. Martin Transfer \& Storage Co., 4 IIl. 2d 273, 123 N.E.2d 540 (1954). This decision accordingly subrogated the employer on common law principles, a technique necessitated by the temporary invalidation on constitutional grounds of the indemnity section in the Illinois workmen's compensation act. 
common feature also of subrogation claims by a fire insurer which could not include any loss of profits by the insured nor other consequential damages. It should be as sufficient in the former as it is in the latter case that there is subrogation pro tanto. ${ }^{113}$

\section{Maintenance and Cure}

The shipowner's obligation of maintenance and cure for injured seamen is a judicially created form of social security, entirely independent of notions of fault. ${ }^{114}$ Though lacking statutory guidance, inaritime law has closely followed the model of workmen's compensation in opposing double recovery as well as favoring recoupment from tortfeasors. Since the extension of maintenance and cure to shoreleave accidents, this policy has gamed considerably in practical importance. Thus a seaman must give credit to his employer against maintenance and cure for any medical expenses he has already recovered fron any third-party tortfeasor. Likewise, if lie joins his employer and the tortfeasor as defendants, the former is liable only to the extent that damages for inedical expenses cannot be collected froin the latter. ${ }^{115}$ The tortfeasor rather than the employer is said to be the "primary" debtor. The employer, first to pay maintenance and cure, should then have a right of indemnity from the tortfeasor. Yet on that question authority is deeply divided.

A 1927 decision of the Second Circuit ${ }^{116}$ dismissed such a claim primarily on the ground that general principles of tort hability stood in the way of recovery of damages for neghigent interference with employ-

113 The problem of "partial subrogation" (see Annot., 140 A.L.R. 1241 (1942), 166 A.L.R. 870 (1947)) arises most frequently in connection with automobile collisions when the insured motorist is insured against property damage and has an additional claim for personal mjuries. Under the majority view in this country, the two claims cannot be split. See Annots., 62 A.L.R.2d 977 (1958), 92 A.L.R.2d 147 (1963). And, statute apart, the claim for collision damage must be brought in the name of the imsured, even when he has been indemnified already by the insurer. See Annot, 96 A.L.R. 864 (1935). But this does not preclude the insurer from advancing a claim to a share in the insured's recovery. See text at notes 215-221 infra, for the manner of apportioning the competing claims in case of lump sum awards or settlements.

114 A negligent shipowner, far from having a right of indemmity, is even denied contribution which is limited to collision cases. Halcyon Lines v. Haenn Ship Ceiling \& Refitting Corp., 342 US. 282 (1952). A right to indemmity may, however, arise from contract, as in the prominent situation of accidents to longshoremen when the shipowner, liable for unseaworthiness, may claim indemnity from a stevedoring company whose negligence, or even non-negligent breach of implied warranty of workmanlike service in supplying defective equipment, caused the injury. Italia Societa v. Oregon Stevedoring Co, 376 U.S. 315 (1964).

115 Seeley v. City of New York, 24 F.2d 412 (2d Cir. 1928); Petterson v. S.S. Jefferson Myers, 45 F.2d 162 (2d Cir. 1930); Thibeault v. Boston Towboat Co, 28 F. Supp. 152 (D. Mass. 1939), aff'd, 108 F.2d 813 (1st Cir. 1940).

110 The Federal No. 2, 21 F.2d 313 (2d Cir. 1927). 
ment relations and that the relation between seaman and master was essentially contractual rather than based on status. ${ }^{117}$ Opposed to this conclusion is a 1946 decision of the Third Circuit ${ }^{118}$ which, avowing a preference for the analogy of father and child, allowed recovery. Its authority is unfortunately somewhat bighted by the fact that the court proceeded on the premise, universally acknowledged as erroneous, that the right to indemnity was a question of state law, even if maintenance and cure was clearly maritime. ${ }^{119} \mathrm{~A}$ faint shadow is also cast on its authority by the subsequent refusal of the United States Supreme Court to allow such a claim by the United States government for payments expended on injured servicemen. ${ }^{120}$ But the situations are hardly alike, and one cannot but agree with the leading authors in the field that the above-nentioned settled principles of maritune law would clearly make any denial of indemnity look capricious. ${ }^{121}$

\section{Occupational Fringe Benefits}

Subrogation has prevailed not only in the sphere of workmen's compensation, but has also become the nodel for recouping other kinds of benefits conferred by collateral sources on tort victinis. Most closely akin are claims by employers for contractual fringe benefits, especially where the arrangement is designed not so much to augment, as simply to provide a substitute for, workmen's conpensation, as in situations where workmen's compensation does not happen to cover the particular type of employment bike that of firemen or policemen. This is the area in which the old action for loss of services has been most often pressed into service. Its fatal flaw, however, is that it provides no safeguard against double liability if, as under the prevailing American doctrine, the collateral source rule fails to reduce the tortfeasor's liabihity to the person injured by a corresponding amount. ${ }^{122}$ The theory of subrogation, on the other

117 The additional 'causal' argument, that the master's payment was caused by his contract, not the defendant's tort, is discussed above. See text accompanying note 56 supra.

118 Jones v. Waterman S.S. Corp., 155 F.2d 992 (3d Cir. 1946).

110 See United States v. Manzanillo, 190 F. Supp. 229 (D. Ore. 1960) which yet preferred Jones to The Federal No. 2 qua federal maritime law. On the other hand, in Houston Belt \& Terminal Ry. v. Burmester, 309 S.W.2d 271 (1957), the Texas court dismissed the intervening shipowner's claim on the ground that general maritime law did not apply in Texas, and Texas laws did not recognize a right of reimbursement absent an express assignment.

120 United States v. Standard Oil Co., 332 U.S. 301 (1947). See note 31 supra.

121 GmMORE \& BLACK, ADMTRAITX 271-77 (1957). The opposing decisions of the two circuits, perhaps because they appeal to general principle as their framework of reference, have attained an importance far beyond maritime cases. One or the other has been frequently cited as authority by opponents and proponents of indemnity from tortfeasors. See text accompanying note 127 infra.

122 See text accompanying notes 70-72 supra. 
hand, accomplishes the object of preventing double recovery without any concomitant double liability. ${ }^{123}$ It is therefore of singular potential on the American scene so long, at least, as the collateral source rule is not discarded.

Pennsylvania, the stoutest champion by far of the compensatory principle, ${ }^{124}$ has also been the pioneer, ${ }^{125}$ of subrogation as the proper means for an employer to recoup wages and medical expenses spent in behalf of an employee. ${ }^{126}$ The analogy of the conventional right of recovery by persons who incurred such expenses pursuant to a legal duty of supportparent, husband and wife-has thus been expanded to avail also those whose obligation is only contractual. This transition was facilitated in the most crucial of the earlier cases because the claimant was a ship's master whose obligation of "maintenance and cure" was of a higher order: a legal-contractual hybrid. ${ }^{127}$

This principle of subrogation has long since been extended to all employment relations. ${ }^{128}$ Necessary to its success, however, is-paradoxically enough - the integrity of the collateral source rule, since there must be a right in the employee to which the employer can claim to be

123 Thus if the employee has already recovered or released his claim, the employer fails in limine. This occurred in Standard Oil Co. v. Umited States, 153 F.2d 958, 963 (9th Cir. 1946), where the soldier had accepted a settlement. True, the trial court secmed to think that, having received free hospitalization and continued wages, he could not have laid claim to such loss, but the Ninth Circuit ruled that the collateral source rule applied and that, therefore, the soldier's release, which extended to "all claims of every nature and kind whatsoever," covered his lost wages and medical expenses. For the government's claim based on loss of services see note 47 supra.

124 See note 131 infra.

125 Outside of Pennsylvania, few courts have explored this theory. But all which did have rejected it. Virginia dismissed such a claim (in excess of indemmity allowed by statute) for want of any equity of restitution. City of Richmond v. Hanes, 203 Va. 102, 122 S.E.2d 895 (1961). Rather oddly, the only other two states to rule against such a claim would also have disallowed any claim on the part of the employec, thus revealing a paramount policy to relieve the tortfeasor in direct opposition to the generally prevailing dogma. The first is Alabama, rejeeting in a series of companion cases, claims by the city of Birmingham for disability pay to various policemen based on all conceivable theories. City of Birmingham v. Walker, 267 Ala. 150, 101 S.2d 250 (1958); Annot., 70 A.L.R.2d 464, 475 (1960). In the companion case of City of Birmingham v. Trammel, 267 Ala. 245, 248, 101 S.2d 259, 262 (1958), the court expressly rejected as irrelevant that the pay. ments precluded the policemen from recovery against the tortfeasor. New York continues to condone claims for lost services. Mineral Indus., Inc. v. George, 44 Misc. 2d 764, 255 N.Y.S.2d 114 (Sup. Ct. 1965). It has, however, repeatedly ruled against claims for medical expenses and wages paid, not uninfluenced by legislative background. Employers Liab. Assur. Corp. v. Daley, 271 App. Div. 662, 67 N.Y.S.2d 233 (1947).

126 City of Philadelphia v. Philadclphia Rapid Transit, $337 \mathrm{~Pa} .1,10$ A.2d 434 (1940).

127 Jones v. Waterman S.S. Corp., 155 F.2d 992 (3d Cir. 1946).

128 Most of the reported decisions deal with claims for disability pay and medical expenses of firemen and policemen. City of Philadelphia v. Philadelphia Rapid Transit, $337 \mathrm{~Pa}$. 1, 10 A.2d 434 (1940); see cases cited in notes 131-32 infra. 
subrogated. Yet it is precisely those jurisdictions with a strong commitment against double recovery that are also, for that very reason, the strongest opponents of the collateral source rule. This dilemma still remains without authoritative resolution in Pennsylvamia. In the first case to give a nod of approval to the theory of subrogation, ${ }^{129}$ the injured employees, city firemen, had originally claimed the same items (wages and inedical expenses) in their own right, but apparently failed to adduce evidence of such a loss and consequently suffered a directed verdict against them. Their failure was probably due to the then prevailing Pennsylvamia rule that they could not charge the tortfeasor for wages they actually continued to receive and expenses they had not incurred. It must have been all the inore galling, therefore, when the city's claim for loss of services was dismissed, with the hardly consoling comment that these items should in the first instance have been claimed by the firemen themselves, and that the city, instead of bringing a separate suit for loss of services, should have intervened in the proceedings by their men. Yet later cases in Pennsylvania have not only on occasion sustained recovery for such items by employers in independent proceedings for loss of services, ${ }^{130}$ but have also performed the even more agile feat of at once continuing to insist that employees cannot recover themselves because they would have suffered no injury, ${ }^{131}$ while sustaining such claims by employers on a theory of subrogation. ${ }^{132}$

\section{English Law Reform Committee}

The subrogation doctrine pioneered in Pennsylvania received a notable boost from the recommendation of the English Law Reform Committee $^{133}$ to abolish what hittle remains in England of the action for loss of services, while conferring in its stead a statutory clain on an employer for reimbursement of expenses incurred on behalf of an injured employee to the extent that the wrongdoer's liability to that employee has thereby been reduced. ${ }^{134}$ Without enlarging the class of persons to whom the tortfeasor owes a duty of care, this reform has the aim only of ensuring that

128 City of Philadelphia v. Philadelphia Rapid Transit, supra note 128.

130 Jones v. Waterman S.S. Corp., 155 F.2d 992 (3d Cir. 1946).

131 Kite v. Jones, 389 Pa. 339, 132 A.2d 683 (1957); Feeley v. United States, 337 F.2d 924 (3d Cir. 1964). Hence an employer would fail in claiming a share of what his employee recovered from the tortfeasor, as this would not have included anything on account of wages lost or medical expenses-a reason that would have sufficed to defeat the employer's claim for such a declaration in the New York case of Employers Liab. Assur. Corp. v. Daley, 271 App. Div. 662, 67 N.Y.S.2d 233 (1947), where a similar obstacle prevails because of the rule in Drimkwater v. Dinsmore, 80 N.Y. 390 (1880).

132 Potoczny v. Vallejo, $170 \mathrm{~Pa}$. Super. 377, 85 A.2d 675 (1952); Topelski v. Universal South Side Autos, Inc., 407 Pa. 339, 180 A.2d 414 (1962).

133 Law Reform Committee, Eleventh Report, Cam. No. 2017 (1963).

184 Id. at 11 (Recommendation 3). 
the beneficent subvention of a third party does not inure to the advantage of the tortfeasor. Subsidiary recommendations, such as to reduce the employer's claim in the same proportion as the employee's would be on account of contributory negligence or the receipt of social security benefits, serve the same purpose of not increasing the tortfeasor's potential liability to the employee. ${ }^{135}$ Although, for tactical reasons, conferring a direct action on the employer against the tortfeasor was thought preferable to relegating him merely to a claim against the employee for a share of the latter's recovery, ${ }^{136}$ its practical effect would be much the same as that of a derivative claim based on the conventional model of subrogation.

The report, while not yet acted on by the British Parliament, furnished the basis of a law passed by the Israeli Knesset in $1964 .{ }^{137}$ It goes beyond the English recommendations in conferring a claim to reimbursenient not only on employers, but on all who incur expenditure or render services in order to repair bodily harm caused by the tortfeasor, whether they do so in discharge of an obligation, imposed by law or contract, or assumed voluntarily. This discloses an embracing legislative purpose of providing incentives for coming to the aid of others in distress, including "good Samaritans" who have elicited legislative support also in recent years in the United States ${ }^{138}$ and elsewhere. ${ }^{138}$

\section{Express Assignment}

Very similar in function to subrogation, and often essential to it for enforcement, is assignment of the beneficiary's cause of action to his benefactor. German law, for example, interprets employment contracts

135 Id. at 11 (Recommendation 5). For critical comment on certain aspects of this recommendation see note 197 infra.

136 Id. at 11 (Recommendation 7). It was considered undesirable to make the employer's recovery dependent on cooperation by the employee, since the latter might have little incentive to claim damages or might have to be forced to refund a portion of bis recovery to the employer. Paragraph 15 of Recommendation 7 contains special recommendations to invoke costs sanctions against unnecessarily separate proceedings by employer and employee.

137 Shalgi, A Benefactor's Right of Action Against a Tortfeasor: A New Approach in Israel, 29 MODERN L. Rev. 42 (1966).

138 More than thirty "Good Samaritan" statutes bave been enacted in the past decade. These statutes exonerate doctors and certain other persons rendering first aid in emergency situations from hability for at least ordinary negligence to shield them from imagined harassment by ingrates. See Loutselt \& Wirliams, Trial of Medicax Matpractice Cases ch. 21; Note, Good Samaritans and Liability for Medical Malpractice, 64 Couus. L. Rev. 1301 (1964); Note, California Good Samaritan Legislation, 51 CaLIF. L. Rev. 816 (1963). The Cahiforma provision for compensation for persons who suffer injury in alding law enforcement presents a different legislative pattern. See CAL. PEN. CODE $\$ \$ 13600-03$.

130 The most important of these are the schemes of compensation for victims of crimes of violence. Those enacted in Britain and New Zealand since 1963 probably inspired the more modest [above-mentioned] California plan launched in 1965. See Fremmo, LAw OF TORT AND Its SOctal Function 59-60 (1966). 
as impliedly imposing an obhigation on the employee to assign his tort claim to the employer with respect to any wages paid him during disability. ${ }^{140}$ The common law technique of subrogation, being automatic in operation, seems preferable since it avoids the necessity of resorting to legal process in order to compel a recalcitrant employee to assign.

But while the common law has had no need for implied assignment, express assignments are occasionally encountered. A good example springs from the practice of the Veterans' Administration to take such assignments from veterans admitted to free treatment in a veterans' hospital. . $^{141}$ The stratagem is most vulnerable in jurisdictions which prohibit the assignment of causes of action for personal injuries. Although assignability used to be linked to survival, and causes of action for personal injuries have almost everywhere been made transmissible on death, many of these statutes have either expressly or by construction retained the old rule against assignment inter vivos, as a safeguard against the ancient evils of trafficking and maintenance. ${ }^{142}$ This, for example, is the position in California and, although express assignment after rendition of free medical treatment may conceivably be distinguished from prior assignments, the latter at least have been declared invalid in this state, ${ }^{143}$ as well as in Virginia. ${ }^{144}$ In contrast, Ollahoma, which permits assignment of personal injury actions, has upheld an express assignment to the Veterans' Administration of the claim for the value of medical treatment. ${ }^{145}$

Moreover, so fragile is the putative legal policy against assiguments of causes of action where it still survives, that courts have generally condoned its circumvention by favorably distinguishing assignments of the proceeds of recovery ${ }^{146}$ and sucli well-known insurance devices as trust or loan receipts whereby the assured undertakes to hold the proceeds of any recovery pro tanto in trust for the insurer ${ }^{147}$ or repay the latter out of such recovery..$^{148}$

140 See text accompanying notes 186-87 infra.

141 Pursuant to 38 C.F.R. $\$ 17.48(f)$ (1966), promulgated under the Veterans Benefits Act, 72 Stat. 1141 (1958), as amended, 38 U.S.C. $\S 610$ (1964). The tortfeasor cannot invoke the collateral source rule to escape liability for the cost of free treatment to a veteran. Hudson v. Lazarus, 217 F.2d 344 (D.C. Cir. 1954).

142 See text accompanying note 98 supra.

143 Fifield Manor v. Finston, 54 Cal. 2d 632, 354 P.2d 1073, 7 Cal. Rptr. 377 (1960).

144 City of Richmond v. Hanes, 203 Va. 102, 122 S.E.2d 895 (1961).

145 Montgomery Ward \& Co. v. Furlong, 219 F.2d 726 (10th Cir. 1955).

146 E.g., Remsen v. Midway Liquors, 30 Ill. App. 2d 132, 174 N.E.2d 7 (1961). This is also accomplished by sanctioning limitations on coverage aimed at shifting the loss from tortfeasor to insurer. See, e.g., Barmeier v. Oregon Plyysicians' Serv., 194 Ore. 659, 243 P.2d 1053 (1952); note 214 infra.

147 E.g., Remsen v. Midway Liquors, supra note 146.

148 E.g., Nat'I Shawmut Bank v. Johnson, 317 Mass. 485, 58 N.E.2d 849 (1945). 


\section{Social Security Legislation}

Most of the world's social security schemes maintain a common front against beneficiaries enriching theinselves from cumulative recoveries..$^{140}$ In general, this object is accomphished by conferring a right on the social security fund to recoup benefits paid by, or payable from, the tortfeasor just as under workmen's compensation. ${ }^{160}$ This is the situation in France, ${ }^{151}$ Germany, ${ }^{152}$ and even Soviet Russia. ${ }^{153}$

In Britain, as is well known, an odd compromise was foisted on the statute book by trade union pressure. While the Beveridge Report ${ }^{154}$ and the Monckton Committee on Alternative Remedies ${ }^{155}$ had set their face against any coinpromise with the compensatory axioin, the formula that

149 There are few deviates, apart from the United States. See note 161 infra. One such exception exists in Switzerland. Swiss law, in common with its European neighbors, generally prevents double recovery by allowing subrogation for most kinds of social insurance. E.g., Bundesgesetz uber die Kranken und Unfallverischerung [Federal Law of Sickness and Accident Insurance for Employees] art. 100, June 13, 1911 [1911]; 1 OFTINOER, SCrWWETERISCHES HAFTPFIICHTRECHT 396-97 (1958). Cumulative recovery is tolerated, however, under the law providing invalidity and survivors pensions on the ground that the sums involved were (originally) so small that the burden of subrogation was disproportionate. Bundesgesetz Alters und Hinterlassenenverischerung [Federal Law of Old Age and Survivors' Insurance] (Dec. 20, 1946); 1 OFringer, op. cit. stipra, at 398. This has not passed without criticism. Sec, e.g., thesis by Schläppi, Der Rückgriff der öffenthichen Pensionkassen des Bundes (Bern, 1964).

150 In some countries the same effect is substantially achieved by compelling recipients to repay benefits out of the proceeds of any recovery from the tortfensor and reducing future benefits in the light of such recovery. See text accompanying note 206 infra.

151 See note 164 infra.

152 See note 183 infra.

153 Under the newly promulgated PrInciples of Civir Legrsiation (U.S.S.R. 1961), the person injured may recover tort damages to the extent that they exceed his social insurance benefits (arts. 91 and 92); but the social insurance organization has a right to reimbursement from the tortfeasor by what amounts in effect to subrogation (art. 93). This right is especially important since defendants are denied the protection of liability insurance, mcluding automobile liability insurance. See Barry, Russians and Their Cars, Survey, Oct. 1965, pp. 98, 109. Liability insurance is still disowned as "unsocialist," although adopted by Czechoslovakia, Poland and East Germany. It also means that social insurance does not assume a role analogous to our workmen's compensation by which the employer can hedge himself against all liability for work accidents. Gray, Soviet Tort Law: The New Principles Annotated, 1964 U. Irr. L.F. 180. The earlier law is discussed by Hazard, Personal Injury and Soviet Socialism, 65 HARv. L. REv. 545 (1952).

154 Inter-Departmental Committee on Social Insurance and Allied Services, Report, Card. No. 6404, \& 260 (1942).

155 Departmental Committee on Alternative Remedies Final Report, Card. No. 6860, §§ 31-38 (1946). The Committee specifically addressed itself to, and dismissed, (1) the analogy of private insurance on the ground that the latter was a reward for individual thrift, and (2) the argument that damages were inadequate to compensate especially the more serious injuries on the ground that this was true only in the sense that disablement can really never be measured in terms of money. In addition, cumulative recovery was considered to provide undesirable incentives for pursuing common law claims and litigation. 
eventually emerged from the parliamentary process was that, in token of the contribution by employees of $5 / 12$ to the fund (equal to that of employers, with the remaining $1 / 6$ coming from general tax revenue), ${ }^{156}$ the injured party need not give credit to the tortfeasor for more than one-lialf of any industrial injury or disablement or sickness benefits, receivable over the first five years after the accident. ${ }^{157}$ In contrast to most other countries, the National Insurance system also discountenances any right whatever to reimbursements from a tortfeasor, preferring the view that the latter miglit as well take the advantage (to the extent that his total hability would be reduced $)^{158}$ because he would, after all, have been a contributor himself and, in any event, the high cost and imvidiousness often associated with subrogation did not make the game worth the candle. Since this is the model also for industrial injury benefits, which replaced workmen's compensation, it constitutes a major departure from the generally prevailing tradition ${ }^{159}$ of relieving social welfare funds wherever possible by passing the cost to the tortfeasor and the risk community he represents. ${ }^{160}$

In the United States, finally, workmen's compensation apart, the customary pattern of laissez faire prevails in relation to Social Security as to other collateral benefits. This means both that the tortfeasor's lia-

160 The English scheme is based on fiat-rate contributions. Contrary to popular American thought, it is exceedingly modest in the scale of its benefits, by American even more than other Western European standards, and rejects any socialist philosophy of social security which would require complementing benefits according to need by contributions according to ability. The latter philosophy prevails in Australia where social security contributions are levied on the same progressive scale as income tax. (In the United States the rate is based on a fixed percentage of income and is thus also regressive.)

Beveridge, author of the modern British system, was a conservative Liberal. As A. J. P. Taylor so trenchantly remarked, "[He] took over the principle of flat-rate contributions, which Lloyd George had unwillingly accepted in 1911, and so perpetuated, seemingly for ever, the retrograde principle of the poll-tax, against which Englishmen had revolted as long ago as 1381." A. J. P. TAYLOR, EnglisH History 1914-1945, at 567 (1965).

157 Law Reform (Personal Injuries) Act, 1948, 11 \& 12 Geo. 6, ch. 41, § 2(1). See also Mayne \& McGregor, Damages 665-67 (1961); Street, Damages 86-88 (1962). The legislative history is penetratingly related by Friedmann, Social Insurance and the Principles of Tort Liability, 63 HARv. L. Rev. 241 (1949). The compromise was foreshadowed by the proposal of the Trade Union Congress that the injured person, if an enployee, should retain five-twelfths of the amount of the benefit in addition to damages. See Departunental Committee on Alternative Remedies, Final Report, Cmo. No. 6860, If 35 (1946).

$158 \mathrm{In}$ other words, the tortfeasor will get a credit for the remaining half of the abovementioned henefits and the total of any others, such as unemployment benefits (Parsons v. B.N.M. Laboratories, [1964] 1 Q.B. 95 (1963)), except for National Assistance, which is a supplementary gratuity based on exceptional need. Foxley v. Olton, [1964] 3 All E.R. 248.

150 This includes the system previously in force in England. Workmen's compensation had allowed the employer a right of indemnity against the tortfeasor. The 1936 National Health Insurance Act provided a whole network of rules to ensure that tort injuries should not become a charge of the scheme. 26 Geo. 5 \& 1 Edw. 8, c. 32.

160 For a fuller discussion see text accompanying note 251 infra. 
bility is not reduced ${ }^{161}$ as well as that, in general, there is neither a statutory nor common law right of recoupment nor any other device for preventing Social Security from becoming a source of actual enrichment to the accident victim. Such exceptions as do exist are sporadic and entirely unsystematized. ${ }^{162}$

\section{E. French and German Law}

The most poignant impression left by a survey of foreign, especially French and German, law is that the identity of the issues under review is matched by debate barely distinguishable, to the point of detail, from our own. In this context at least, vaunted differences in legal technique between civilians and common lawyers are suppressed by the more exigent search for viable solutions.

All these systems present a common front in categorically adhering to the compensatory principle and rejecting the notion of cumulative recovery, save in the case of private insurance. ${ }^{103}$ That an accident victim should actually come out better is as incompatible with the purposes of tort law as it is extravagant of the community's resources. Because "the primciple of the thing" is to the European mind too important to be cavalierly sacrificed to administrative considerations, there is no disposition to heed arguments that the amounts derived from collateral sources are hardly worth the bother of relocation nor apt in any event to enricir the beneficiary because tort damages rarely compensate fully for his losses in case of personal imjuries.

Moreover, it is generally considered as so self-evident that the tortfeasor should not take advantage of collateral benefits received that reimbursement prevails as the general regime without so much as any extended discussion of its comparative merits or justification. In the stock situations such as social security and disability pay or pensions for government employees, authority for recoupment is found in statutory

161 United States v. Hayashi, 282 F.2d 599 (9th Cir. 1960), and cases collected in Annot., 84 A.L.R.2d 764 (1962). Nor is there, as already mentioned (note 71 supra), any support for an exception in case of "services rendered gratuitously by a state-supported or other public charity."

162 One such provision for reimbursement relates to unemployment pay during disability under the Railroad Unemployment Insurance Act, 60 Stat. 739 (1946), as amended, 45 U.S.C. $\S 362(0)$ (1964). See Tate v. Jacksonville Terminal Co., 127 So, 2d 702 (Fla. 1961). Another example, already noted, is the assignment provision for benefits under the Veterans Administration hospital scheme. See note 141 sttpra.

103 The fullest exposition of the French law is found in 1 MazeAud er TUNC, RESPONSABLTTE CIVIIE, COMUL DES INDEMaNTTÉS, §§ 233-71 (6th ed. 1965). A much briefer account is given in 2 SAVATIER, Responsabitite Civm.e no. 585-89, pp. 157-63 (2d ed. 1951).

The German doctrine of "Vorteilsausgleich" is well explained in gencral terms by 1 Larenz, Lezrbuci Des Schut.drecets 131-33 (3d ed. 1960). See also Cantzler, Vorteilsausgleich beim Schadenersatzanspruch, 156 ARCHIV FUR ZIVIISTISCHE PRAXIS 29 (1957). 
regulation-not in any overriding code section or article of general ambit, but incidental to each individual social welfare measure. ${ }^{164}$ This web of special regulations today covers most of the field and is the more pervasive because of the all but universal coverage of social security benefits during disability-which, modest though they inay be, are available to plug the most immediate and urgent needs of those who meet with illness or accident.

The principal interest, from the point of view of the present inquiry, focuses on the disposition of those residuary situations which are not subject to statutory prescription but are resolved on the basis of general principle. These residuary cases raise profitable comparison, especially in the doctrinal area, with our own problems and their solution.

\section{France}

French law, tied to the axiom that subrogation must be a creature of statute, has been driven to explore the possibility of an independent tort action as an alternative device for securing recoupment. On this question, however, issue has been joined-dividing both doctrine and jurisprudence, learned literature as well as court decisions-over whether the claimant can be regarded as having suffered a genuine loss as the result of the defendant's fault.

Is there "damage" sufficient to qualify as an injury under article 1382 of the Code Civil? ${ }^{165}$ The argument of the opponents is most formidable with respect to private insurance. For it is familiar ground to the commonlaw lawyer, ${ }^{166}$ no less than to the civilian, ${ }^{167}$ that an insurance company

164 The general outlines of the French law are conveniently drawn for the Englishspeaking reader in CoNARD, AUtomorme ACcment ch. 13 (1964). Readers with larger linguistic pretenses will find a succinct treatment in Rouast, DURAND ET DUPEYRoux, SÉcurté Soctate 283-86 (social insurance), 413-20 (work injuries) (1961). As regards social insurance, the statute expressly subrogated the fund to the rights of the injured (subrogée de plein droit). Art. L 397 CODE DE SÉc. Soc. As regards work injuries, for no very obvious reason, the statutory formula was somewhat different: the injured person's damages were reduced by the value of his benefits (i.e., limited to the complément d'indemnité), the fund having a right of reimbursement for the remainder. Art. L 470 CODE DE SÉc. Soc.

German law has a uniform provision for automatic passing (cessio legis) of the injured person's rights to the social insurance funds to the extent of the benefits disbursed. REICHSVERSICHERUNGSORDNUNG (Aichberger ed. 1954) [hereinafter cited as GERMan SoctaI Securrty Code] § 1542 .

165 There seems to be general agreement that the Code supports an action for the value of lost services. But the servant must be "irreplaceable," like a skilled engineer. De la Morandière, [1958] Dalloz Chromque, 183-84, emphasizing the admonition for a conservative approach in 1 MAZEAUD ET TUNC, op. cit. supra note 163, no. 277-86.

108 Simpson \& Co. v. Thomson, 3 App. Cas. 279 (1877); Connecticut Mut. Life Ins. Co. v. N.Y. \& N.H.R.R., 25 Conn. 265, 65 Am. Dec. 571 (1856); Sinram v. Penn. R.R., 61 F.2d 767 (2d Cir. 1932).

1671 MAZEAUD ET TUNC, op. cit. supra note 163, at $\S 253$. 
cannot pretend to have suffered loss in any meaningful legal sense in having to meet its obligations to the assured, even if the contingency is brought about by tortious conduct of the defendant, for the good and sufficient reason that it was prepared to assume that risk, was paid for it and calculated it into its rate structure. For the insurer to duck his obligations and pass the loss to the tortfeasor is conventionally permitted only in those exceptional situations where subrogation is recognized as a means for vindicating the overriding principle of indemnity, paramount in property (including fire and collision) and liability insurance. In sum, to connive at an independent tort action by the insurer would be for the law of torts to give the go-by to a fundamental postulate of the law of insurance. To do so would be unjust to the assured as much as to the tortfeasor; for either the assured would lose his right to collect both his damages and the sum insured or the tortfeasor would be exposed to an additional liability in excess of making good the loss sustained by his immediate victim.

Does this argument lose its puncl when applied to the claim of an employer for recoupment of wages paid to an employee during his enforced absence? Some ${ }^{188}$ argue that it is just as pertinent because the employer is really only paying out deferred wages for which he has already received a quid pro quo. Lest this seem fanciful, let us recall that it is the standard common law argument for permitting the employee to invoke the collateral source rule and keep both the disability pay, as being in reality wages deferred, in addition to full and undiminished tort damages from the tortfeasor.

Protagonists of the opposing view ${ }^{109}$ point both to the unreality of equating the position of an employer or social welfare fund with a conventional insurer and to the different purposes which these arrangements serve. Their sole object being to satisfy need, it would be an unwarranted extravagance as much to permit the injured person double recovery as to condone the tortfeasor taking advantage of the collateral benefit. Finally, to say that payment of the benefit was "caused" not by the tort, but by the contractual obligation is less than realistic, even for a debate in an area that has been notoriously indulgent to metaphysical fancies. For who would deny that the employer has been put out of pocket by having to continue wages without getting any corresponding benefit of labor as the direct consequence of the disabling accident caused by the defendant's culpable conduct?

168 The most prominent champion of this viewpoint was the Doyen de la Morandière, De l'action des administrations contre le tiers responsable de l'accident survenu d $u n$ membre de leur personnel, [1958] Dalloz Chronique 179.

${ }^{109}$ For a sanguine exposition of this viewpoint see R. Meurisse, [1962] Semaine Juridique 12737, commenting on a decision of his court, cout de grande instance de Verdurn. 
While these skirmishes on the theoretical level have remained inconclusive the course of practice has decidedly hardened. The weight of judicial opinion was already leaning heavily towards recovery by social insurance funds before this was finally endorsed by statutes in the immediate post-war period. ${ }^{170}$ Hence the practical range of controversy has now polarized around payments by employers over and above social security benefits. In this residuary area also, French courts appear to have finally settled in favor of recovery. ${ }^{171}$

Quebec jurisprudence has gone its own way in a demonstration of typically Gallic independence. Iatching on to a textual difference between its Civil Code and the Code Napoleon, ${ }^{172}$ the Supreme Court of Canada eventually deferred to the insistent Quebeçois view that no independent action could be based on tort principles as it can under French law. ${ }^{173}$ This, however, opened the door to the alternative theory of unjust enrichment. ${ }^{174}$ Accordingly, the employer inay recover for wages paid as well

170 With this important difference, however, that whereas prior case law had endorsed a direct action based on CODE CIVII art. 1382 (1804), many of the statutes (e.g., CoDE DE SEc. Soc. art. L. 398) confer a right of subrogation just as in the case of private insurance. 1 MLAZEAUD ET TUNC, op. cit. supra note 163, at \& 267.

171 This appears now settled, at least for the time being, by a decision of l'Assemble e plemère of April 30,1964. While strictly concerned only with the rights of public organizations, it is generally thought to apply with equal force to private employers. $I d$. at $\$ \S 271-72$.

An employer may also seek reimbursement from the social security funds, if he has not in the first instance deducted the appropriate amount from his employee's wage packet. Therefore, if he continues to pay his employee full wages during disability pursuant to an individual or collective labor contract, he is automatically subrogated (de plein droit) to the employee's social security disability allowance (indemnités journalières). To the extent that the employee has already received any disability allowance, he must account for it to the employer.

Because recovery apart from statute is for "damage suffered" by the payer, gifts are excluded just as they are at comnion law. Since the injured person would not have to give credit for donations in reduction of tort damages, this conclusion also saves the tortfeasor from double hability. Id. at $\$ 271$.

172 Unlike the latter, the former contains an article providing specifically for wrongful death claims by designated dependents. QUEBEC CIv. CODE art. 1056. On the maxim expressio unius est exclusio alterius, the argument prevailed that this excluded all other direct claims by persons suffermg damage as the result of injury, no less than as the result of the death of another.

${ }^{173} \mathrm{La}$ Reme v. Sylvain, [1965] Can. Sup. Ct. 164, vindicating the dissent of the Quebeçois minority in the earher case of Regent Taxi \& Transp. Co. v. Congregation des Petits Frères de Marie, [1929] Can. Sup. Ct. 650. Sylvain was more recently applied, again in a case involving a serviceman, in La Reine v. Plamondon, [1965] 1 Can. Exch. 778. Not without piquancy, Fauteux, J., speaking for the Court in Sylvain, also relied on de la Morandière's argument that there was no loss in such a case, without mention that this argument has found no support from French courts. See note 168 supra.

174 French law does not permit the actio de in rem verso for unjust enrichment unless all other avenues for redress are closed. Thus the action has played no part in metropolitan France in this context, once it became established that a tort claim could be pressed. The theory is carefully explained by Dumoulin, J., in La Reine v. Sylvain, [1965] I Can. Exch. 261, 269 (1963). See also Caster, The CivI Law Systear of Quebec ch. 6 (1962). 
as for medical expenses on the ground that the tortfeasor was to that extent unjustly enriched..$^{175}$

By contrast, all attempts in common law jurisdictions to enlist the doctrine of unjust enrichment have singularly failed. Besides a few tepid attempts before American courts, ${ }^{176}$ the most earnest was the belated attempt by an English city to press its claim as a last resort for securing reimbursement of wages paid to an injured policeman, after all earlier claims based on the more conventional action for loss of services had been defeated. ${ }^{177}$ That claim was also dismissed with the reply that the city was actually no worse off than it would have been if the accident had never occurred, being under an obhgation to pay its officers whether they were on duty or off duty througli disablement. Nor, for that matter, had the tortfeasor gamed a benefit in any real sense, because his duty was to do no more than make good the damage he had done, and this did not happen to include loss of wages because they had already been paid. The trouble with this retort is that its blustering robustness, typical of the late Chief Justice Goddard, fails rather dismally to meet the nub of the plaintiff's argument. Much inore sensitive to the realities of this complex situation was the German Supreme Court's admonition that any preliminary hypothesis as to whether the employee had suffered damage should not block further inquiry into equitable allocation of the real cost of the accident. ${ }^{178}$

\section{Germany}

German law is categorically committed to denying an independent tort action to anyone other than the accident victim himself. Persons only

175 Besides the last-mentioned decision, this theory was championed by the dissent in Regent Taxi \& Transp. Co. v. Congregation des Petits Frères de Marie, [1929] Can. Sup. Ct. 650 and by the Supreme Court of Canada in La Reine v. Sylvain, [1965] Can. Sup. Ct. 164. In each instance, however, the claim failed because it was statute-barred. The leading decision is Paquin v. Grand Trunk Ry., 9 Sup. Ct. 336 (1885), where a doctor recovered from the tortfeasor for the services rendered to the victim.

176 In City of Richmond v. Hanes, 203 Va. 102, 122 S.E.2d 895 (1961), for cxample, a claim for subrogation was pressed, in the last resort, on the ground that the city, by continuing wages, had thereby paid the debts of the tortfeasor. The contention was dismissed for want of any showing that it had "acted in the performance of a legal duty or occupied the position of a surety; or that it acted in self-protection against a loss it might suffer if it did not pay; or that it acted in response to a request of [the person injured]." Id. at 108, 122 S.E.2d at 900 . A similar claim invoking the authority of section 76 of the Restatement of Restitution (indemnity for paying another's debt) failed in Crab Orchard Improvement Co. v. Chesapeake \& Ohio Ry., 115 F.2d 277 (4th Cir. 1940).

177 Metropolitan Pohce Receiver v. Croydon Corp., [1957] 2 Q.B. 154 (C.A. 1956). See Street, Damages 78-81 (1962).

178 "Durch die allerdings am Anfang stehende Frage der Entwicklung eines Shadens darf der Bhick für die weitere Frage des Schadesausgleiehs und der Berechnung des wirklich enstandenen Shadens micht versperrt werden." "7 Entscheidungen des Bundesgerichtshofes in Zivilsachen [hereinafter cited as B.G.H.Z.] 49 (June 19, 1952). This report is discussed below. See note 188 infra. 
immediately (or, as we would say, consequentially) injured have no general claim to reparation, save in two specified instances: (1) where a person fatally injured owed a legal duty of support to surviving dependents; ${ }^{179}$ and (2) where a person injured or killed was by law under a duty to render services in the household or enterprise of the claimant (as in the case of an injured minor child). ${ }^{180}$ In no event do contractual obligations furnish the necessary nexus. In all of these respects German law is hardly at variance with our own except in not makmg provision for an action for loss of services by an employer. But then, after all is said and done, neither really does the Anglo-American law of today.

Thus, in contrast to the French, German law was forced to explore the path of subrogation in search for a doctrinal basis to support recoupment of expenses. The center of interest revolves around the mandatory requirement of the German Civil Code that the employer continue to pay full wages to disabled employees for six weeks, ${ }^{181}$ during which period social security benefits are now suspended. ${ }^{182}$ It has therefore become a matter of material concern whether he can shift the cost to the tortfeasor, just like social security funds ${ }^{183}$ and governmental employers ${ }^{184}$ on whom special statutes have expressly conferred a right to recoup their expenses. The solution eventually found, after some disappointing flirtation with unjust enrichment, ${ }^{185}$ was in a creative and statesmanlike enlisting of assignment as the appropriate device. Bent on encouraging aid to victims of distress, the courts did not falter, even in the face of seemingly prohibitory code language, in permitting them to assign their

\footnotetext{
179 BÜ̈GERLICHE GESETZBUCH § 844, II 2 (11th ed. 1960) [hereinafter cited as GerMaN CrVII, CODE].

180 Gerasan Civit Code $\$ 845$.

181 Geraran Civil Code § 616.

182 This is a relic of the Brüning, passed originally in 1930-31 under emergency powers in order to rehabilitate the social security funds (Krankenkassen). The story is fully documented by Drs. G. \& D. Reinicke in their excellent article, Zur Frage des Übergangs von Schadenersatzansprüichen auf Arbeitgeber und Versicherungsträger, 6 NEUE JURISTCBE WOCEENSCHRIFT 1243 (1953) [hereinafter cited as N.J.W.].

183 German Soctat Security CODE § 1542. A full account is found in Wussow, UNPAILEAFTPFLICETRECET 747-805 (8th ed. 1963).

184 Deutsches Beamtengesetz $\S 139$ [hereinafter cited as Government Employees Act]; Bundesbeamtengesetz \& 168 [Federal Government Employees Act].

$185 \mathrm{Or}$, more specifically, with the theory of restitution for expenses incurred as negotiorum gestor in the defendant's behalf (Geschäftsfiuhrung ohne Auftrag), a theory which is recognized as proper enough in case of support rendered by a person under a legal duty to do so, like a parent or husband. Unjust enrichment, strictly-speaking (Ungerechtfertigte Bereicherung), has made no headway especially in the last-mentioned situations because of the explicit provision (Geraran CrvII CODE $\$ 845$, II 4) that the tortfeasor cannot reduce his liability on account of subventions due from a third party. A penetrating insight is provided by Dawson, Negotiorum Gestio: The Altruistic Intermeddler, 74 HaRv. L. Rev. 817, 851-59 (1961).
} 
rights pro tanto to their benefactors. ${ }^{180}$ But while volunteers continue to depend on express assignment, those who render support pursuant to a legal obligation, like employers, have been put into the even more favored position of actually being entitled to an assignment from the victim to the extent of any benefits conferred. ${ }^{187}$

The only remaining doctrinal problein, once the employee's duty to cede his rights against the tortfeasor had thus become established, was how to affirm that there remained any such rights, seeing that the employee had as the result of the subvention suffered no actual net loss. In other words, whereas the perplexity of the French is over whether there is injury to the employer, the Gernans' is over whether there is injury to the employee.

The specter of the circulus vitiosus is broken, to the satisfaction of the German Supreme Court ${ }^{188}$ and preponderant professional opinion, ${ }^{180}$ by the proposition that the employer's payments do not so much negate the loss as that they shift it from the employee to the employer. What

180 The landmark decision was pronounced by a joint session of all civil divisions of the Supreme Court (Grosser Senat für Zivilsachen): 4 B.G.H.Z. 153 (Dec. 10, 1951). Dawson describes it enthusiastically as "an astonishing feat of judicial creation of law." Dawson, supra note 185, at 857 . The prohibition against encumbering or ceding this kind of claim (GERMan Crvir CODE § 400) was overcome with the argunent that the protective purpose of this provision-to prevent wage earners from whittling away their livelihoodwould be furthered rather than impeded by allowing assignments in favor of a benefactor to encourage speedy assistance to persons in need. The assignor would not be prejudiced in the least, so long as he could assign no more than the value of benefits actually received. This solution also assured that the tortfeasor would not get off more lightly-as be might well otherwise have done if damages were reduced by the amount of the collateral benefitor, alternatively, that the injured person would not get double recovery.

187 To afford maximum safety to the beneficiary, cession is limited to the value of the corresponding benefit received from the assignee. Repeated assignments are obviated since a general assignment is permitted but can be enforced only as each benefit is received.

Similarly, there is automatic subrogation (cessio legis) in favor of the state ( $\$ 139$ Government Employees Act) and social insurance carriers (Geraran Soctar. Security Code \$ 1542), in contrast to the requirement of assignment in other cases, beeause the former are presumed to be always solvent, unlike private employers who are therefore not entitled to call for a transfer of rights until they have bestowed the benefit.

188 In two decisions, the first by the third senate of the Bundesgerichtshof (Zivil) in 1952 (7 B.G.H.Z. 30), reafirmed by the seventh senate in 1956 (9 N.J.W. 1473). The Swiss Supreme Court is in accord (58 II Bundesgerichtes 249 (1932)) with respect to wages paid by the employer under a corresponding provision of the Swiss Civil Code (Art. 335) copied from the Gerasan Crin Code $\$ 616$. See also 1 Oftinger, Schweizerisches HafTPFLXCETRECHT 308-09. (2d ed. 1958).

189 A full bibliography is found in Siebert, Schadenersalz und Lohnfortzahlhung, in FESTSCBRIFr FǘR HEDNRICH LEHMAANN 670 n.3 (1956). For a comparison with the critical tone of the preceding article, see Sieg, Schadenersats und Versorgang, 9 JURISTISTEN ZETTUNG 337 (1954) and Drs. Reiniclse, Zur Frage des Ubergangs von Schadentersatzanspruchen auf Arbeitgeber und Versicherungsträger, 6 N.J.W. 1243 (1953). There is a brief note in English by Mann, The Problem of the Policeman's Pay-The German Approach, 20 ModERN L. REV. 290-91 (1957). 
precludes the employee from recovering is not that he has suffered no loss, but that he would be enriched. There being a loss, therefore, he can and must cede any right accruing therefrom to his employer who, concededly, is himself out of pocket and thus qualified to recover. Conceding the German court's strong motivation in favor of recoupment ${ }^{190}$ compared with the want of policy orientation ("neutral principles"?) endemic among the Englisl, it acquitted itself with much greater agility in coping with doctrinal snares than the English courts have managed hitherto in comparable contexts. ${ }^{191}$

\section{Contributory Fault}

Suppose that the tortfeasor is liable for less than the whole of the damage-because, for example, of the plaintiff's contributory negligence, or of a fixed monetary ceiling for damages, as under the Warsaw Convention or some other strict liability statute, like the German automobile liability act. How is the available compensation to be adjusted as between the victim and a collateral source that has met part of the victim's loss?

Let us lrypothesize that the plaintiff lias suffered an injury amounting to 1,000 dollars, that his claim against the tortfeasor is worth 500 dollars and that lie received 600 dollars from the collateral source. Three solutions are feasible. First, the plaintiff's claim can pass to the collateral source in full, with the result that he is himself 400 dollars out of pocket. The collateral source having absolute priority, this may be designated as the "absolute theory." Second, the plaintiff satisfies his own loss in full, passing only the residue to the collateral source ("differential theory"), so that in our example the plaintiff could keep 400 dollars, leaving only 100 dollars for the insurer. Third, the collateral source is entitled to an amount bearing the same proportion to the tortfeasor's liability as its obligation to the plaintiff does to the total loss ("relative

100 In addition to the numerous statutory analogies, see as symptomatic the decision by the combined divisions of the Supreme Court (GrZS) in 1953, allowing recoupment to the Kasse (social security fund) for survivor benefits paid to dependents of an invalid who was already receiving a disability pension at the time of his death at the hands of the tortfeasor. The decision is trenchantly criticized by Drs. Reinicke, supra note 182, at 1245-47, on the ground that the claimant suffered no loss, being in truth relieved from continuing benefits to the deceased.

191 See especially Metropolitan Pohce Receiver v. Croydon Corp., [1957] 2 Q.B. 154 (C.A. 1956) where the English Court of Appeal stressed the somewhat similarly formulated question whether the employer, by continuing to pay wages, had reheved the tortfeasor from a "loss" he had caused by his negligence. By contrast, a Canadian court recently made short shrift of the argument that, the employee having continued to receive wages from his employer, the latter could not recover these from the tortfeasor because there was nothing to which the workmen's compensation statute entitled him to be "subrogated." Nilsen \& Metropolitan Toronto v. MacGregor, [1965] 2 Ont. 733, 52 D.L.R.2d 15 (Ont. H.C.). 
theory"), which would entitle the plaintifi to 200 dollars and the collateral source to 300 dollars.

Choice from among these alternatives should be based on a reasoned sense of the relative priority between the interests of the injured person and the particular collateral source. Their relation differs greatly from one to another, depending on the purposes of the particular subvention. Private insurance quite clearly falls within the second group. In case of accident and life insurance, so paramount is the interest of the insured that lie can, as we know, keep both cumulatively. And even as regards subrogable insurance, since the purpose of subrogation is primarily to vindicate the principle of indemnity, it is deferred to the insured's interest to be made whole. Hence if the fortfeasor cannot be made to pay more than a fraction of the damages, the insured is given absolute priority.

German $^{192}$ and French ${ }^{183}$ law are at one in applying the "absolute" rather than the "differential" theory in favor of social security funds, even when (as is usually the case) the injured has made substantial contributions himself. Thus if the latter receives 600 dollars from the fund and the claim against the tortfeasor is reduced by one-half to 500 dollars, the fund may claim all, so that the plaintiff is 400 dollars out of pocket. This solution has not passed without criticism. ${ }^{194}$ Opposing the "pubhi" interest of social security to the "private" interests of the injured does not compel the conclusion that the latter should be subordimated to the former. It still leaves open for serious consideration which of these competing interests is on balance more deserving. In that light, is there not much to be said for passing the loss to the community rather than to

192 This is the subject of an admirable article by Drs. G. \& D. Reinicke, Zum Quotenrecht der Versicherungs-und Versorgungsträger, 7 N.J.W. 1103 (1954). See also Wussow, op. cit. supra note 182, at $\S 1912-14$. There is no compelling statutory provision in Germany as there is in France, but the courts have consistently adhered to the absolute theory in deference to the "public interest" of the Kassen and governmental employers, like the State and its subdivisions.

193 In case of work accidents, absolute preference is conferred on the Caisses by art. L. 470, Code de SEC. Soc. Rouast, Durand et Dupexroux, SÉcurtit Soctare $\$ 262$ (3d ed. 1961). In the residuary situations, the Cour de Cassation has followed suit. This solution has the full support of MAZEAUd ET TUNC, Responsabitite CrVIIE §§ 266-67 (6th ed. 1965). For the position of private employers, see note 196 infra.

The employer's own negligence is debited to the Caisse in scaling down the latter's right of recoupment from the tortfeasor. This is analogous to the law of California, though it does not har, but only reduces the claim. Cf. note 106 supra. Art. L. 470, Code DE SEC. SOc. ROUAST, DURAND ET DUPEXROUX, op. cit. supra.

104 Besides Germany and France, it also prevails in Switzerland (85 (II) Bundesgerichtes 256 (1959)). See also Maurer, Zun Regressrecht der Schweizerischen Unfallversicherungsanstalt, in ScHWEIz. ZETTSCHRITT F. SOzTALVERSICHERUNG 227 (1957); 1 OFTINGER, op. cit. supra note 188, at 372-75 (2d ed. 1958) and Italy (Cour de Cass., 16 May 1958, [1958] Diritto del lavoro 469). 
the individual who has made contributions? Social security, no more than private insurance, is a handmaiden to the policy underlying the defense of contributory neghigence which, in any event, would still play a role in depriving the plaintiff of the balance between the tortfeasor's reduced tort hability and the totality of the loss. The popularity of the absolute theory ${ }^{105}$ thus emphasizes all the more how deep-seated is the prevailing conviction against allowing a tort victim to "profit" at the expense of social security.

Continental authority is well-nigh silent on the proper adjustment in the case of benefits paid by a private employer. ${ }^{108}$ The Law Reform Committee in England which recently recommended introduction of a statutory right to reimburseinent added the proposal that it suffer reduction in the same proportion as the injured employee's own claim does against the tortfeasor under the "comparative negligence" statute. ${ }^{107}$ One may surmise that this qualification was prompted by the impression that, thougln it might give the employer less than a full indemnity, ${ }^{198}$ any other solution could unfairly expose the tortfeasor to excessive liability. That this would be a wrong assumption, however, is a lesson tauglit by continental experience. As we have just seen, a social security fund inay recoup the whole of its outlay. But this adoption of the "absolute" theory in preference for the "relative" confers only an absolute priority over the accident victim; it does not stretch beyond the latter's rights against the tortfeasor. ${ }^{199}$ Let us assume that the employee was one-third to blame, that his total injury amounts to 1,200 dollars of which 600 dollars has been met by social security payments. Reimbursing the latter in full would leave 200 dollars for the victim; while reducing the claim propor-

105 See especially Reinicke, supra note 192.

196 Although the French legislator deliberately gave the Caisses the benefit of the absolute theory (note 192 supra) what little authority there is points to proportionate reduction (the relative theory) for recoupment by private employers of payments beyond the value of social security benefits. $R$. Meurisse, [1962] Semaine Juridique 12737, approving a decision to that effect by the trihunal de Verdun de lege lata, though deploring it de lege ferenda.

197 Law Reform Committee, Eleventh Report, CMD. No. 2017, at II 10 (1963).

108 This relegates him for the residue to a possible claim against the culpable employee himself for the residue. That he has such a claim was placed beyond doubt in Lister $v$. Romford Ice Co., [1957] A.C. 555. See note 229 infra.

100 In cases of claims for loss of services by parents or husbands, the English law actually allows full recovery undiminished by the tortfeasor's liability to the child or wife, on the view that the cause of action is independent. Mallett v. Dunn, [1949] 2 K.B. 180; Curran v. Young (1965) 38 Austl. L.J.R. 452 (H.C. 1965). Flemrng, Torts 626-27 (3d ed. 1965). This relates to a time when an imputation of contributory negligence would bave defeated the claim entirely, as it does under the prevailing American doctrine. Prosser, ToRTs 914-16 (3d ed. 1964) (expressing strong disapproval). German law also invokes identification, but only with the result of reducing danages. GERMar CivIr CODE $\$ 846$. 
tionately would increase the victim's take to 400 dollars. ${ }^{200}$ Thus the tortfeasor's interests are not affected one little bit by whichever theory is selected; the difference impinges only on the adjustment between the competing interests of the claimants inter se. One concludes therefore that the English proposal does not so much reflect a deliberate tenderness for the interests of employees, comparable to the opposite preference consciously given by French and German law to social security funds, as a failure to probe fully the alternative solutions available.

\section{II}

\section{REFUND OF BENEFITS}

Aside from recoupment from the tortfeasor, two other techniques are available for limiting the accident victin to no more than an indemnity without at the same time letting the tortfeasor escape the full measure of his liability. The first alternative is for the injured person to refund the benefit. Its marked advantage, if such it be esteemed, consists in the fact that it lessens the pressure on the collateral source to take the initiative against the tortfeasor and thereby conceivalbly to place the accident victim himself in an invidious position. If the latter does not desire to vindicate or test his rights against the tortfeasor, the collateral source would have to defer to that wish, lacking legal standing to sue in its own right or even to enforce any right to sue derivatively.

A second mark of superiority which the technique of refund has over any independent right of recourse is that it does not inhibit settlements. The great majority of all accident claims are settled before trial, but a tortfeasor (or his insurer) cannot hope to close his books on the incident until all viable claims have been released. Merely settling with the injury victim is not enough, if there remain any outstanding claims for indemnity. This difficulty is obviated if, vis-à-vis the tortfeasor, the interest of any collateral source is nnerged in the cause of action of the injury victim himself. That is the case both with subrogation and the theory of refund.

The stock example of an obligation to return a benefit is a conditional gift. If a gratuity is conferred with the understanding that its equivalent, or a part thereof, be repaid to the benefactor in case the donee succeeds in a recovery from the tortfeasor, it would be enforceable at the instance of the donor once the contingency occurred. Less orthodox is the practice, occasionally resorted to by English courts, of imposing the condition that the plaintiff repay his benefactor out of what he recovers from the tort- 
feasor. ${ }^{201}$ This would of course be quite improper, if the donor's intent had been that the donee keep the gift in any event; but such is far from always the case, and the question is really whether the court should assume the initiative of loss shifting in circumstances not specifically provided for by the parties. The idea has been attacked on the ground that what the plaintiff does with his damages is nobody else's concern, not even that of his creditors, and still less that of someone who has at best a moral clain on him. ${ }^{202}$

This retort, however, does less than justice to the practice criticized. In the first place, the well-known axiom it invokes addresses itself only to the question whether it hes in the tortfeasor's mouth to contend that the person he has injured could or would not make proper use of the damages awarded to him; it has nothing to contribute to the problem of loss distribution as between the accident victim and the benefactor. Secondly, implicit in the criticism seems to be the old-fashioned assumption that all a court may properly take into consideration is the effect its disposition will have on the immediate parties before it. In the field of torts, one would have thought, the "new learning" alone about loss distribution should long have amply demonstrated the exigent need for a higher level of judicial statecraft. In the present context to disregard the "third factor" as a inatter of principle is to condemn all discourse to futility. However that may be, it would be idle to take too sanguine a view of the prospects of this particular judicial innovation.

The pattern of refunding benefits has not remained exclusively linked to the model of conditional gifts. Conditional undertakings to repay are encountered also in more formal contexts. ${ }^{203}$ In the insurance world, it

201 Dennis v. London Passenger Transp. Bd., [1948] 1 All E.R. 779. Denning, J., was obviously trying to prevent the tortfeasor from insisting on a reduction of damages by the amount of wages thus received. Without going quite so far as directing the donee to repay, a Canadian court allowed the donee recovery in full from the tortfeasor upon undertaking to repay the donor. Myers v. Hoffman, [1955] Ont. 965, 1 D.L.R.2d 272. Even English law does not permit the tortfeasor to set off wages, etc., received by the plaintiff on condition of repayment. Wolland v. Majorhazi, [1959] N.Z.L.R. 433; Browning v. War Office, [1963] 1 Q.B. 750, 759 (C.A. 1962); Terry v. Lotocky, [1961] 28 D.L.R.2d 640, 35 West. Weekly R. (n.s.) 335 .

202 See, e.g., Blundell v. Musgrave, 96 Commw. L.R. 73, 96 (1956); Street, Damages 76-77 (1962).

203 "Gifts which may not be retainable and loans which may not have to be repaid,"although once disparagingly described as "a brood of devices, misshapen creatures," Windeyer, J., in Commissioner for Rys. v. Scott, 102 Commw. L.R. 392, 462 (1958)-really owe their popularity to the law's inability to provide more straightforward means for meeting an unquestionable demand. If they evoke an adverse reflection, it is on the inflexibility of the law, rather than on the ingenuity of lawyers. Lord Goddard's admittedly robust mind did not share Justice Windeyer's sense of delicacy in actually recommending the device of loans as a means to encourage considerate employers, relatives and friends making advances to an injured person. This would not diminish the latter's recovery and adequately protect the 
is the model for so-called trust receipts or loans in which the assured undertakes to refund any insurance payments out of the proceeds of an award or settlement with a tortfeasor. ${ }^{204}$ Abroad, the technique has been incorporated into some public employment contracts to secure return of fringe benefits, ${ }^{205}$ and given an even more official sanction in social security legislation hike New Zealand's. ${ }^{200}$ Besides, it is widely utilized by public hospitals ${ }^{207}$ as well as under privately funded health plans. In either of these situations, as an alternative to taking an assignment of the patient's riglits (the policy followed by the Veterans Administration), ${ }_{2}^{208}$

interests of the benefactor. Inland Revenue Comm'rs v. Hambrook, [1956] 1 All E.R. 807, 813.

204 See Remsen v. Midway Liquors, 30 Ill. App. 2d 132, 174 N.E.2d 7 (1961), discussed note 101 supra.

${ }^{205} \mathrm{~A}$ striking instance of such an institutionalized pattern is found in the English Scheme of Conditions of Service of the National Joint Council for Local Authorities Administrative, Professional, Technical and Clerical Services. Paragraph 16(3)(f) provides: "An officer who is absent as the result of an accident shall not be entitled to an allowance if damages are receivable from a third party in respect of such an accident. In this event, the authority inay, having regard to the circumstances of the case, advance to the officer a sum not exceeding the sickness allowance provided under this scheme, subject to the officer undertaking to refund to the authority the total amount of such allowance or the proportion thereof represented in the amount of damages received." See Conaro, AutomronILE ACCDENT Costs and Payarents 430 (1964).

${ }^{206}$ Section 71 of the New Zealand Social Security Act provides, inter alia, that (a) where any damages or compensation has been granted, benefits may be denied or reduced, and (b) benefits may be granted on condition of repayment if the applicant recovers damages or compensation, and such benefits may then be recovered by the Commission and constitute a charge on the damages. Social Security Act, N.Z. STAT. no. 136 (1964). For further comment see note 224 infra.

207 This, for example, is the techmique employed by the Australian armed services in treating injured servicemen in military hospitals. See Blundell v. Musgrave, 96 Commw. L.R. 73 (1956). But as Bhendell illustrates, successful implementation of this refund techmique requires avoiding the prevailing British rule that a tortfeasor is bable only for medical expenses incurred. The patient's liability to pay for his treatment must therefore be formulated so as to be clearly independent of his right to recover damages. Hence, the lospital can neither make the charge conditional on his recovering damages, nor, what is even worse, purport to provide free treatment with the understanding that, in case of a subsequent recovery, the patient be billed. Instead, whenever there is a rcasonable chance of successful tort proceedings, the hospital should in the first instance make a charge for its services, prepared though it might be to remit it if the tort claim eventually fails.

The above problem may lave its counterpart in the United States. Ordinarily a defendant cannot avoid liability for medical treatment on the ground that the plaintiff would have received it free if unable to get compensation or damages. See, e.g., Reichle v. Hazie, 22 Cal. App. 2d 543, 71 P.2d 849 (1937). Under the Veterans Administration practice, however, in a case where free treatment for veterans furnishing an affidavit of inability to defray the necessary expense was required by statute, an assignment taken by the Adninistrator of all tort claims against a third party was held not to cover "expenses actually incurred" within the meaning of an insurance policy. United States v. St. Paul Mercury Indem. Co., 238 F.2d 594 (8th Cir. 1956).

208 See note 141 supra. 
the patient may be formally charged for the treatment, on the understanding that the bill will not be collected if he fails to recover damages. This for instance is the current practice under two of the most favored health plans in California, the Kaiser Foundation ${ }^{209}$ and the California Physicians' Service. ${ }^{210}$

This refund technique has the great advantage of not being vulnerable, like assignment or conventional subrogation, to the objection that causes of action for personal injury are unassignable. ${ }^{211}$ For such a clause in the membership contract does not purport to transfer all or any part of the subscriber's cause of action in tort; it merely imposes on him a conditional contractual obligation to pay for the services rendered to him. Even insofar as it may confer a lien on the proceeds of any judgment or settlement, it is still no different from that of an attorney's contingent fee contract in a personal injury action, long ago held to be beyond challenge. ${ }^{212}$ Admittedly such a provision for refunding has been ruled to violate the basic law of disability insurance in California, ${ }^{213}$ but the reasons for this conclusion are peculiar to the statute law governing

209 Group Medical and Hospital Service Agreement, 6. Exclusions and limitations, B(4): "Injuries Caused by Third Parties. In case of injuries caused by any act or omission of a third party, and complications incident thereto, services and other benefits requested lereunder will be furnished but will be charged at Prevailing Rates. However, the Member shall not be required to pay any amount in excess of the total amount collected on account of the injury."

210 California Physicians' Service Family Health Service Agreement, Personal Protection Plan, Series 930, part 7C: "Acts of Third Parties. If the Member is injured through the act or omission of another person CPS slall provide the benefits of this Agreement, only on condition that the Member shall agree in writing: (1) to reimburse CPS to the extent of benefits provided, immediately upon collection of damages by him, whether by action of law, settlement or otherwise, and (2) to provide CPS with a lien, to the extent of benefits provided by CPS. The lien may be filed with the person whose act caused the injuries, his agent or the Court."

211 This is the position in California. Fifield Manor v. Finston, 54 Cal. 2d 632, 354 P.2d 1073, 7 Cal. Rptr. 377 (1960) (life-care contract); Peller v. Liberty Mut. Fire Ins. Co., 220 Cal. App. 2d 610, 34 Cal. Rptr. 41 (1963) (medical payments clause in automobile policy). See also note 98 supra.

212 Casseta v. Del Frate, 116 Cal. App. 255, 2 P.2d 533 (1931); Bartlett v. Pacific Nat'l Bank, 110 Cal. App. 2d 683, 244 P.2d 91 (1952). The validity of these contingent fee contracts rests on the distinction between assignment of a cause of action and assignment of the proceeds thereof.

21334 Ops. CaL. Atr'y Gen. 247 (1959). This opinion upheld the Insurance Com. missioner's disapproval of a refund, no less than a subrogation, clause in a disability insurance contract. The provision for reimbursement was viewed as inconsistent with standard provisions for disability insurance policies-laid down in regulations promulgated pursuant to a statutory grant of rule-making power by the Commissioner-which require payment of claims within a specified time after filing and obviously contemplate prompt and final settlement. A subsidiary objection to the refund clause was that it could not pass the test of fairness unless the refund was limited to the amount of recovery attributable only to medical expenses. Such an objection, however, is applicable only to liens and assigaments of proceeds, and not to contractual obligations to repay. 
contracts of insurance and do not appear relevant to other health plans, akin though they may be in function. ${ }^{214}$

One interesting, if subsidiary, objection that has been voiced against the refund technique is that, insofar as it may be chargeable against any damages recovered from the tortfeasor, such refund might quite unfairly exceed what has been received by way of reimbursement for medical expenses. ${ }^{215}$ Rarely, if ever, do jury awards or settlements identify the various heads of damage, several of which (pain and suffering, loss of earnings) represent losses entirely different from the "specials" for the cost of medical care. While some may think it "manifestly unfair"10 that the injury victim should have to repay more than is clearly attributable to what he has received from the tortfeasor on the same account, the legislature evidently thought differently when the analogous lien, under the Workmen's Compensation Act, was expressly extended to the entire amount of any judgment recovered by an injured workman against a third party. ${ }^{217}$ Other imstances of such an "absolute" charge conferred on a collateral source we have already noticed in dealing with the rights of German and French social security funds in cases where the victim was guilty of contributory neghigence and his tort claim against the tortfeasor was correspondingly reduced under a régime of comparative negligence. ${ }^{218}$ Moreover, this objection, if taken seriously, would fatally taint almost all settlements which invariably make allowance for all manner of forensic contingencies, thus reducing (presumably proportionately) the various items of claim, including medical expenses. ${ }^{219}$ But though this argument

214 Such a clause was upheld by the Oregon court in Barmeier v. Oregon Physicians' Service, 194 Ore. 659, 243 P.2d 1053 (1952), which specifically noted the distinction between assignment of personal injury actions and mere contractual obligations to repay. Contracts for prepaid medical and hospital service by organizations operating solely for the purpose of providing service rather than indemnity fall outside the field of insurance regulation. See California Physicians' Service v. Garrison, $28 \mathrm{Cal}$. 2d 790, 172 P.2d 4 (1946); CaL. INS. CODE $\$ \S 11491-517$. The remaining argument based on fairness was considered not sufficiently cogent to invalidate the clause and, in any event, irrelevant to purely contractual claims.

21534 Ops. Cax. ATT'y Gen. 247, 257-59 (1959).

216 This description was once applied in an argumentative dictum to a case uploolding the employer's right of reimbursement under the workmen's compensation act. Jacobsen v. Industrial Acc. Comm'n, 212 Cal. 440, 299 Pac. 66 (1931).

217 Cax. Lab. Code § 3856. See Dighton v. Martin, 4 Cal. App. 2d 401, 41 P.2d 197 (1935).

218 See text accompanying notes 192-93 supra.

219 The same argument has been pressed against the proposal to allow an employer a right to recoup from the tortfeasor the amount by which the latter's hability to the injury victim was reduced as the result of the employer's expenditures. In case the tortfeasor settled with the employee, "it would be to the employee's interest to attribute the lion's share of the lump sum to general damages by asserting that the total of the claim (swollen by a generous estimate of general damages) had been heavily discounted for the risk of 
is not a sufficient reason for categorically barring refunds any more than subrogation, ${ }^{220}$ one may sympathetically endorse the practice of certain health plans of making allowance, as a matter of administrative discretion and fairness, for the fact that the subscriber had to settle for substantially less than his normal and reasonable expectation, besides any pro rata reduction on account of his attorney's fee. ${ }^{221}$

\section{III}

\section{TERMINATION OF PERIODICAL BENEFITS}

Minimizing the cost of compensation schemes without prejudice to its intended beneficiaries can, perhaps, be most expeditiously accomplished by terminating benefits as soon as the need has been met by tort damages. Most, if not all, social security systems, including workmen's compensation, offer benefits by way of periodical installments rather than lump

complete or partial failure on the issue of liability." Law Reform Committee, Eleventh Report, CArb. No. 2017, at 13 (1963) (minority report).

220 In connection with subrogation, the problem arises most frequently in cases of automobile accidents where the injured person is insured against damage to his car and presses a claim also for personal injuries. The prevailing view is that if the amounts attributable to the two items are not segregated in the award or settlement, the burden is on the insured to show that less than full satisfaction was made for the property loss. Thus in Home Ins. Co. v. Slater, 28 Del. Co. Rep. 546 (Pa. 1937), the insurer recovered the full amount although the verdict was smaller than the combined claims warranted. In the English case of Horse, Carriage and Gen. Exch. Ins. Co. v. Petch, 33 T.L.R. 131 (1916), where the insured had released the tortfeasor from all claims for a lump sum without the insurer's consent, the court invoked the following argument: Since the insured had no right to settle, he could not complain for being treated as laving settled for the full amount, especially when the insured's loss would have been the amount of damages had he been sued by the insurer for breach of contract for depriving the insurer of his right to conduct the claim. These diffculties can be overcome however. See General Exch. Ins. Co. v. Driscoll, 315 Mass. 360, 52 N.E.2d 970 (1944), where the tortfeasor gave the injured person's attorney two checks by way of settlement, one specifically marked "property damage." The insurer was held entitled to that sum after allowance for apportioned collection expenses.

It seems to be common ground that, in situations where a set-off is required for benefits received from the defendant himself-in other words, where the benefit was not "collateral"- the set-off is required only against the same kind of items. Hence the value of free medical services cannot, or at all events should not, reduce damages awarded solely for pain and suffering or loss of earnings. That was the position taken in United States v. Gray, 199 F.2d 239 (10th Cir. 1952). See Feeley v. United States, 337 F.2d 924, 934 (3d Cir. 1964).

221 According to information supplied by the counsel's office, the Kaiser Foundation plan firmly adheres to this guideline. For reasons mainly concerned with good customer relations, there is nothing like a persistent systematic enforcement of the refund clause. Only recoveries at minimum administrative cost are pursued. No investigative staff is maintained, and attention to third party recoveries is in general only drawn when counsel for the person injured requires documentation from the plan for claiming the cost of medical treatment from the tortfeasor. In Oregon, the regional management appears to be more firmly committed to maximizing revenue from this source; in contrast, the health plan in Hawaii deliberately omitted the refund clause from its inception in 1958. 
sums. At least with respect to future benefits, therefore, it is administratively simplest to shift the loss to the tortfeasor without at the same time enriching the beneficiary by simply terminating the grant of the pension or other emolument. Besides, it is least apt to be a source of embarrassment in the relation between the collateral source and the injured person, since it offers little scope for pressuring an unwilling victim to put the squeeze on the torfeasor-a consideraion not unimportant in automobile accidents where the latter is quite likely to be a member of the same family and not carrying adequate insurance. ${ }^{222}$ Finally, the termination technique dispenses with all the technical difficulties incident to direct recoupment of determining what precise annount is reclaimable from the tortfeasor. For instance, the inost notorious handicap burdening the French social security system is precisely its inability to recover at any one time more than the sum of past installments paid. ${ }^{223}$ Even without such an impediment, there remains the endemic challenge to accountants to prove their art of capitalizing the present value of future disbursements.

For all these reasons, the technique of setting off damages against benefits has long enjoyed a fair measure of support. Not infrequently it is combined with such ancillary features as making the grant of benefits initially conditional on repayment if damages are later recovered, ${ }^{224}$ or even withholding benefits if the injured person unreasonably refuses to prosecute his claim for damages. ${ }^{225}$ These refinements, however, are open to the same objections of promoting hitigation and infusing an element of potential embarrassment for the injury victim as characterize subrogation.

Aside from that, a rigorous application of set-off is also apt to create occasional actuarial difficulties in assessing the weekly value of lump-sum payments. Not least of these is that tort damages represented by a settleinent or verdict will include compensation for pain and suffering which, it might well be argued, ought not to be brought into account at all. For

222 See text accompanying note 228 infra.

223 Although deplored in the literature, this is still the position of social insurance and workmen's compensation. See Rodast, Durand ET DUPErroux, StcurIte Sociale §§ 144, 263 (1961).

224 See, e.g., $\S 71(\mathrm{~b})$ of the New Zealand Social Security Act, N.Z. STat. no. 136 (1964). The provision has been in force since 1938. A correspondent reports that "these matters are dealt with automatically by the solicitors for a plaintiff who has successfully recovered damages and my impression is that the section is applied on a fairly wide scale." The English National Health Insurance Act, 1936, 26 Geo. 5 \& 1 Edw. 8, c. 32, § 52, cmployed a slightly more sophistieated techmque of permitting advances to the injured person pending settlement of his claim for workmen's compensation or tort damages. It also provided that, if notice of such payments was given to the person liable to pay compensation or damages, he must deduct an equivalent amount from the compensation or damages and pay it instead to the social security fund.

225 Thus, for example, the now-superseded English National Health Insurance Act, 1936, 26 Geo. 5 \& Edw. 8, c. 32, § 53. 
this reason it is undoubtedly preferable to allow a necessary measure of flexibility by investing the administering agency with a discretion, instead of peremptory duty, to take any compensation or damages awarded into account against the gratuity or pension to such an extent as it may think fit, and withhold or reduce the pension or gratuity accordingly. This pattern prevails in relation to British service pensions ${ }^{226}$ and provided the model for the Social Security system in Australia. ${ }^{227}$ There are probably other examples, and it bids fair to attract even more widespread following in the future.

\section{IV}

\section{RELIEVING THE TORTFEASOR}

The preceding discussion assumed the desirability of holding the tortfeasor to the fullest ineasure of his liability. But for this underlying philosophy of the collateral source rule, our task of exploring techniques to assure that at the same time the victim received no more than full compensation would have been much less exacting. Rid of this fetter, we may not inappropriately close, as we began, with another look at this basal assumption.

Regardless altogether of more transcendent considerations appropriate to loss distribution, there are at the outset at least some situations of not infrequent occurrence in which the accident victim, were he left to his

226 See Payne v. Railway Executive, [1952] 1 K.B. 26 (C.A. 1951), which held that, for this reason alone, the tortfeasor could not set off the pension against his own liability. The rationale was confinned as consistent with the overriding principle of indemnity in Browning v. War Office, [1963] 1 Q.B. 750, 760, 771 (C.A. 1962), and appled in Carrol v. Hooper, [1964] I All E.R. 845 (Q.B.), [1964] I Weekly L.R. 345 (military pension); and Elstob v. Robinson, [1964] 1 All E.R. 848 (Q.B.), [1964] 1 Weekly L.R. 726 (naval pension).

Dissociating himself from the majority report of the Monckton Committee, which recommended a set-off of social security benefits against damages, Beney, K. C., advocated the instant solution of giving the National Insurance fund power to nodify future benefits. "Such an adjustment could be made without any injustice to the injured person, such as might well ensue from deducting from his proper dannages a sum arrived at by such haphazard methods as would be involved in capitalizing future unpredictable weekly sums ...." Departmental Committee on Alternative Remedies, Final Report, Cam. No. 6860, at 58 (1946).

227 The Australian position is not altogether clear in view of some ambiguity in the statutory language. The formula is that "[a]n invalid pension shall not be granted to a person .... if he has an enforeable claim against any person, under any law or contract, for adequate compensation in respect of his permanent incapacity or permanent blindness." Social Services Consobidation Act, \& 25(1)(d), Commonwealth Acts, No. 26 of 1947 (Austl.). There are corresponding provisions for sickness ( $\$ 115)$ and rehabilitation benefits $(\S 135(\mathrm{r})$ ). It has been persuasively argued that this does not cover tort damages. National Ins. Co. v. Espague, 105 Comniw. L.R. 569, 578-9, 587 (1961), per Menzies and Windeyer, JJ. Despite English case law to the contrary, the High Court of Australia has sanctioned treating all pensions as collateral benefits which do not reduce tort damages. Jones v. Gleeson (1965) 39 Austr. L.J. Rep. 258. 
own counsel, would not have wished the ultimate cost to be borne by the tortfeasor, or where sound policy would not be opposed, indeed would even favor, letting the burden remain with the collateral source. Most European legal systems for this reason proscribe subrogation within the family circle. ${ }^{228}$ What the insurance company would give with one hand, it would in effect be taking with the other, if it sought to recover the amount paid to the insured from another member of his family, viewing the family group-as realistically we must-as basically one economic unit. This is all the more true when the tortfeasor happens to be a person to whom the insured owes a continuing duty of support, such as a spouse or minor child.

The invidious position in which exercise of a right of subrogation may place the insured finds illustration also in other contexts. A most prominent example occurred recently in England when the liability insurer of an employer insisted, over the protest of his insured, on reimbursement from the culpable employee whose negligence had caused the injury for whicl the employer had been called to account on the principle of respondeat superior. Even the argument that the employee, a truck driver, had every reason to believe himself to be covered by his employer's insurance as an incident of his employment was held to be of no avail in resisting the claim. ${ }^{22}$ The insurance industry's triumph over this test case was, however, short-lived, since the companies were unable to resist the outraged demand of organized labor, backed by the government, for a gentleman's agreement that they would not enforce their right without express consent from the employer ${ }^{230}$ For the sake of industrial peace, if not from general considerations of fairness, an employer would hardly be prepared to give this consent. Whatever the incentive for disciplining a servant who was merely careless rather than guilty of more heinous conduct, it could be accomplished with less penal impact than by foisting

228 Thus article 36 of the French insurance law of July 13, 1930 prohibits subrogation against "les enfants, descendants, ascendants, alliés en ligne directe, préposés, employés, ouvriers ou domestiques, et généralement toute personne vivant habituellement au foyer de l'assuré sauf le cas de malveillance commise par une de ces personnes." 1 MAzEAUD ET TUNC, ResponsabIITIE CIVIIE §§ 236, 247 (6th ed. 1965).

The German law (Accident Insurance Law $\S 67, \llbracket 2$ ) flatly enjoins subrogation against "einen mit [dem Versicherungsnehmer] in häusslicher Gemeinschaft lebenden Familienangehörigen." The Austrian and Swiss statutes are virtually identical. 2 A. EHRENZwETo, SR., VERSICBERUNGS-VERTRAGSRECHI 556-59 (1935). The Swiss restriction, however, applies only as against family members guilty of merely shight neghigence. See I OFTnNGER, op. cit. stupra note 194 , at $346-48$.

229 Lister v. Romford Ice Co., [1957] A.C. 555. Cf. Continental Cas. Co. v. Phoenix Constr. Co., 46 Cal. 2d 423, 296 P.2d 801 (1956), where the same maneuver succeeded against an einployee truck driver-but one who luckily happened to be insured.

230 See Note, 22 Modern L. REv. 652 (1959); 35 N.Z.L.J. 129 (1959). 
the whole of the accident cost on an uninsured defendant, especially when this would entail the corollary of relieving an insurer who had been paid to assume that very risk and was able to distribute the cost among the premium-paying public. ${ }^{231}$

If subrogation by private insurers is thus widely considered in need of curbing, at least in situations where it would demonstrably defeat public policy, should this not also militate against public forms of insurance like social security? The logic of this argument appears irresistable even against the endemic plaint to reduce the cost of social welfare. The German Supreme Court accordingly, without so inuch as a semblance of statutory authority, recently denied to social security funds a right of subrogation agaimst the husband of the beneficiary, in deference to the philosophy underlying the himitations on subrogation expressly formulated for private insurance. ${ }^{232}$

\section{A. Scandinavia}

Much more radical are limitations on subrogation based on broader considerations of loss distribution, such as the better loss-bearing capacity of one compared with another available source of compensation. This line of thinking is especially associated with, and has made greatest advance in, Scandinavia. ${ }^{233}$ It starts with the premise that any claim to recoupment, depending as it does in the last resort on the legal process, must carry its own burden of self-justification. This is, of course, reminiscent of Holmes' point of departure on his historic quest into the foundations of tort law..$^{234}$ Only, whereas his concern was with the problem of initial liability - that is, with whether the plaintiff deserved compensation at all -our present concern is with whether the cost of that compensation

231 See Parsons, Individual Responsibility versus Enterprise Liability, 29 AUSTL. L.J. 714 (1956); Frenrnve, Torts 692-93 (3d ed. 1965). This criticism is not intended to detract from the useful disciplinary effect of such a cross-claim against an employee guilty of flagrant disobedience or wanton misconduct, as distinct from mere negligence.

2321964 Versicherungsrecht 391 (Nov. 2, 1954); 1965 Versicherungsrecht 386, 18 N.J.W. 907 (Aug. 1, 1965). These two decisions are discussed by Hïskes, Anschhuss der Regressnahme von Socialversicherungsträgern unter Familienangehörigen (\$§ 67 Abs. 2 VVG, 1542 $R V O), 1966$ Versicherungsrecht 20 . The author criticizes the extension, in the second decision, of this rule to an adult brother on the ground that the latter would not have had any legal claim to support from the "insured" and subrogation against him would thus not have been apt to prejudice the "insured" directly.

233 Some excellent literature is now available in English. See Hellner, Tort Liability and Liability Insurance, (1962) ScANDIN. LEgar StOdIES 131; Strahl, Tort Liability and Insurance, (1959) SCANDIN. Legar StudIEs 199; Ussing, The Scandinavian Law of Torts-Impact of Insurance on Tort Law, 1 AM. J. CoMp. L. 359 (1952). I lave also derived the greatest assistance from a thesis (deposited in the Library of the School of Law, University of California, Berkeley) by Basye, Limitations on Subrogation of Insurers in Scandinavian and American Law (1956).

294 Holmes, Tre Comaron LAW lecture III (1881). 
should ultimately be borne by the tortfeasor or by some other régime. While both inquiries deal with the shifting of loss, what is a sound answer for one is by no means necessarily so for the other. Fault, for example, is still, as much as in Holmes' day, considered a generally sufficient reason for tort law to shift the loss from the injured, while prevailing Scandinavian thought deems fault to be generally inadequate to justify recoupment by an insurer or social security organization.

The position that ordinary negligence does not warrant a shifting of the loss to the tortfeasor is defended on the ground that recoupment is for all practical purposes a real issue only as against insured defendants where the deterrent value of liability (on any account highly problematical) is almost completely evaporated. Beyond that, once the injured person's needs have been met, there is no further justification for insisting on the pound of flesh from a tortfeasor guilty merely of ordinary negligence, all the more having regard to the progressively diluted standards of so-called legal negligence. ${ }^{235}$

The final argument agamst subrogation addresses itself to the cost involved. In the first place, collection costs are notoriously high, ${ }^{230}$ and the game is rarely worth the candle. ${ }^{237}$ Agamst this, advocates of subrogation sometimes contend that, in an intensely competitive market the tenuous margin of profitability may be critically affected precisely by the extent to which subrogation recoverers contribute to relieve a particular insurer from the burden of a matured risk. ${ }^{238}$ Besides, it might be argued

235 For American law see HARPER \& JAMres, TORTs passim (1956). For English and Commonwealth law see Freming, Torts passim (3d ed. 1965).

238 See Horn, Subrogatton in Insurance Theony and Practice ch. 7 (1964), which is based on an actual field study which gains in significance because of the author's general enthusiasm for subrogation. When resorting to litigation, and especially outside attorneys, the study estimates that to pay a claim of $\$ 500$ would cost the tortfeasor (or his insurer) $\$ 600$ and the subrogee $\$ 195$; the latter will accordingly only collect $\$ 305$ net. Thus the overhead to the insurance industry is $\$ 295$ on a $\$ 500$ claim. The principal reason for this alarming figure is that the subrogee's attorney works on a contingent fee basis-for which there is really no justification at all.

As regards subrogation claims under $\$ 2,500$ for automobile physical damage (and plate glass), almost all casualty underwriters, as signatories smce 1952 of the Nation-Wide Inter-Company Arbitration Agreement, are bound to submit to arbitration, and with respect to other types of insurance may do so with prior consent. Although arbitration reduces costs to negligible fractions, the savings cannot be precisely identified because of the interminghing of administrative expenses.

237 Exact statistics for subrogation recoveries in the United States are not available. Horn has calculated that, expressed in terms of a rough ratio between net subrogation receipts in a given year to net losses in that year, subrogation recoveries were as high as $12.5 \%$ for auto collision and lower than $1 \%$ for auto fire, theft and comprehensive, reaching a nadir of $.01 \%$ for auto bodily injury. ForN, op. cit. stupra note 236 , at ch. 11 .

238 The criticism is often voiced that subrogation affords a windfall to the insurance company. E.g., Patrerson, Essentrats of Insurance Law 151 (2d ed. 1957). At best, it rewards the efficient organization by increasing its marginal profit. Moreover, there is no 
that the high cost of subrogation constitutes by itself an adequate regulator against its frivolous exercise in situations where it would be uneconomic to do so. This retort however tends to look only at the economic cost to the subrogee. It fails to do justice to the wastefulness of subrogation to the whole process of insurance, particularly in its effect on insurance premiums. Subrogation promotes multiple insurance, since the same risk inust be covered both by damage and lability insurance. The cost of both, moreover, is in many situations spread among the same risk community, as for example, owners and drivers of automobiles. ${ }^{239}$ Thus the high cost of subrogation, added to the administrative expenses of multiple insurance, constitutes a burden on enterprise and the community without any compensating economic, even less than social, advantage.

Subrogation may, on the other hand, in individual cases find an exceptional justification in promoting recognized policy objectives. As against tortfeasors guilty of intentional misconduct or gross negligence, it is justifiable in order to promote accident prevention or deter outright antisocial behavior as an adjunct to the criminal law; ${ }^{240}$ against operators of ultrahazardous activities because they ought to bear the cost of their own peculiar risks as a matter of sound resource allocation; and in all other cases of strict hability-which under Scandinavian law means automobile accidents-as well as where the injury was inflicted "in the course of trade or business" on the additional ground of the defendant's manifest loss-spreading capacity. ${ }^{241}$

basis for assuming that subrogation recoveries, like other recoveries such as salvage, do not enter into rate calculation. See HoRN, op. cit. supra note 236, at 189-93.

239 Thus if the experience mentioned in the preceding footnote were reflected in rate schedules, it would tend to increase liability rates and decrease collision rates. Yet both types of insurance are usually carried by one and the same person who must also foot the cost of subrogation. As a result, the cost of the first is not lowered, and that of the second is increased.

240 This reflects the same policy underlying the common provision in (compulsory) insurance giving the insurer a right to indemnity against drunk drivers. It also inspired Professor Ehrenzweig's advocacy of "tort fines" as an adjunct to his "Full Aid" Insurance for the Trafic Victim-A Voluntary Compensation Plan, 43 CaxIF. L. Rev. 1 (1955).

241 Under our own conventional rules, subrogation for full indemnity has also been permitted to insurers against non-negligent defendants on a theory of strict liability, e.g., common carriers and railroads strictly hable for fire damage under statute, lessees for breach of covenant to repair, and local authorities for riot damage. E.g., Meyer Koulish Co. v. Cannon, 213 Cal. App. 2d 419, 28 Cal. Rptr. 757 (1963). This has been criticized on the ground that the insurer, who voluntarily and for payment assumed the risk, should be demed a right of subrogation altogether. This is commonly done in the closely related cases of surety and non-neghigent defendants, like a good faith purchaser who buys from a dishonest bonded bailee. Northern Trust Co. v. Consolidated Elevator Co., 142 Minn. 132, 171 N.W. 265 (1919). Otherwise, the insurer should share with the defendant on the model of co-sureties. Langmaid, Some Recent Subrogation Problems in the Law of Suretyship and Insurance, 47 HARv. L. REv. 976, 987-95 (1934). This ignores reasons for strict liability other than the "deep pocket," such as accident-preventive pressure. Clearly, subrogation may perform 
This Scandinavian scheme, in effect, hinges on a calculus of loss allocation that bears heavily on basic policies of the law of torts. While not necessarily at cross purposes, it is calculated to infuse a new set of values that may ultimately refashion the whole structure of the tort law of tomorrow. As long, however, as this scheme merely purports to play a peripheral role on the edges of conventional tort law, is there not something a trifle invidious about varying a tortfeasor's liability according to whether his victim happens to be insured or not so that he is let off the hook in the one case, but not the other? In seeking to find an answer to this question, it is at least worth recalling as one of the perennial facts of life that the extent of tort liability has never borne any relation to the magnitude of the defendant's guilt, being entirely dependent on the fortuitous amount of the loss that happens to result. Adding to the multitude of existing variables the new factor of whether the victim turned out to be insured is therefore hardly a radical innovation.

The Scandinavian system of loss allocation is now approaching its first half centennial. ${ }^{242}$ Important as was its original educational impact, its actual operational role remained quite modest so long as it applied only to private insurance-and but a limited segment of that, bearing in mind that no insurance against personal injury (except medical costs insurance $)^{243}$ ever did carry subrogation rights anyway. It received a notable boost, however, by being taken over into Swedish workmen's compensation in $1954^{244}$ and immediately afterwards into the general health in-

functions, as the instant Scandinavian model indicates, other than policing nineteenth century fault morality. The most complete study is Hellner, FörsïKrnncs Grvarens RegressrÄtT (The Insurer's Right of Subrogation) (Uppsala 1953). See also, J. HeLlNer, FöRSÄKRINGSRÄTT ch. 18 (1959).

242 The preparatory committees began work in 1919 and reported their draft in 1925. The insurance law, generally known as FAL (acronym for Försäkringsavtalslagen), was enacted by Sweden in 1927, by Norway and Denmark in 1930, and by Finland in 1933. The crucial subrogation section is uniformly numbered 25 , but the individual laws differ somewhat in detail. In Denmark and Norway the exclusion of subrogation in the designated situations is discretionary ("can be reduced or disappear") and includes, besides ordinary negligence, hability based on respondeat superior. That this runs against the grain of enterprise hability is recognized by Norway, which accordingly himits this exception to cases "where the injury is not caused in the course of tracle or business." All four countries appear to have retained subrogation in cases of strict liability, but by express enactment only in Sweden and Finland.

243 The second paragraph of the twenty-fifth section of the several insurance laws (FAI) excludes subrogation from life, accident and health insurance. Excepted are "insurance proceeds that have the character of an actual indemnity" (Denmark, Norway), or "insurance to pay hospital expenses or other actual costs caused by the accident or illness" (Sweden, Finland). This clarity compares favorably with the ambiguity of Anglo-American law concerning those insurances which are for personal injuries and yet indemnitory.

244 Lag om Yrkesskadeförsakring [hereinafter cited as Industrial Injuries Insurance Act], § 51, May 14, 1954, [1954] Svensk FörfatrnINGssananng [liereinafter cited as S.F.S.] $447, \mathrm{nr} .243$, as aniended, May 25, 1962, [1962] S.F.S. 1000, nr. 408. 
surance scheme. ${ }^{245}$ The plan to abolish all subrogation claims for the latter was defeated by timidity. In the first place, the assumption that the amounts involved would be too small to make collection worthwhile was revised by subsequent estimates of what might be recouped from autoInobile habihty insurers. Secondly, opposition to this solution for workinen's compensation would not have made it possible to adopt it right across the board, and in any event it was beheved that so drastic a reform had better await a general review of the whole framework of tort liability. The compromise of retaining subrogation but drastically limiting it to cases of intentional or grossly negligent conduct and traffic accidentsthat is, against automobile liability insurers-thus came into being. The first exclusion was of course never of any practical significance, and the second so disappointed its originally sanginine sponsors that, on the occasion of a general revision in 1962, all subrogation was finally banished from the scheme of general social insurance. ${ }^{246}$ Thus only private indemnity insurance and workmen's compensation continue a lingering, if rather disenchanted and much curtailed, flirtation with subrogation. Its prospects are considered shorthived by the cognoscenti.

\section{B. Great Britain}

The most categorical repudiation of the philosoplyy underlying the collateral source rule is found in the 1946 recommendations of the Monckton Committee in England, ${ }^{247}$ which were in large measure adopted by Parliament in solving the problem of alternative remedies that attained renewed prominence as the result of the thoroughgoing overhaul of the

245 Lag angående ändring i lagen den januari 1947 (nr. 1) om allmän sjukförsäkring [The Law Amending the General Insurance Law of Jan. 3, 1947], \& 107, May 14, 1954 [1954] S.F.S. 465, nr. 244.

246 Lag om allmän försäkring [hereinafter cited as General Insurance Act], ch. 20, § 7, If 2, May 25, 1962, [1962] S.F.S. 903, $\mathrm{nr}$. 381. It was originally estimated that some ten million crowns (two million dollars) might be recovered from automobile insurers (BIrANG Tint Rirsdagens Protokoli 1954, K. M. Prop. No. 60, at 252), but only about half that sum was ever realized. CONARD, AUTOMroBIrE ACCIDENT ch. 12 (1964). A useful thumbnail

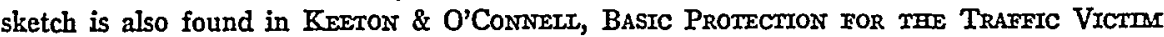
212-17 (1965).

Another difference, which is more important from a techmical than practical point of view, is that in Denmark alone, the plaintiff's recovery is actually reduced by his insurance coverage, whereas in the other countries it is the insurance company that is deprived of its right of subrogation. In the latter, therefore, a plaintiff can still pick his defendant and, by proceeding first against the tortfeasor, rcheve his own insurer. It has been suggested that the tortfeasor be subrogated against the insurer in such an event. See Palmgren, Till Frágen om Försäkringsgivarenz Regressrätt, 1945. TIDSKRIFT UTGIVEN AV JURIDISKA FORENINGEN I FinLand 283, 290.

247 Departmental Committee on Alternative Remedies, Final Report, Cam. No. 6860 (1946). 
whole Social Security system following the Beveridge Report. ${ }^{248}$ After canvassing all the conceivable alternatives, the Committee came down squarely in favor of the compensatory principle that an injured person should not have the same need met twice over, dismissing at once the analogy of private accident insurance (which was a reward for initiative and thrift) as well as the argunent that he would have himself contributed to the cost of the scheme. ${ }^{249}$ This premise was eventually compromised in Parliament by the concession that a plaintiff need not bring into account one-half of the benefit he would receive during the first five years, in token of his own payments. ${ }^{250}$ Secondly, instead of adhering to the existing nodel of a set-off of damages against benefits, the Committee proposed a set-off of benefits against damages. ${ }^{251}$ This ineant that the tortfeasor would in the end get the advantage of these benefits in the form of reduced liability; in sum, that to this extent he would be exonerated at the expense of Social Security.

The reasons given in support of this proposal were essentially negative, aimed at minimizing administrative difficulties rather than positively seeking to promote loss allocation in a particular direction. At the forefront was the conviction that it would be undesirable, especially for a governmental agency, to instigate litigation, perhaps without or even contrary to the wishes of the injured person. Besides, it would involve leavy expenses in maintaining a staff for investigation and in the legal cost of collecting promising claims. Not least important was the pervasive Enghisl concern with reducing the volume of litigation-underlying as it did both the recominendation against any forms of recoupment as well as the initial insistence that the injured person not be allowed more than a single recovery in the hope, indeed, that in all but the very serious accidents he would be satisfied with national insurance benefits and not pursue his chances in common law proceedings. ${ }^{252}$

248 Inter-Departmental Committee on Social Insurance and Allied Services, Report, Casd. No. 6404 (1942).

249 Departmental Committee on Alternative Remedies, Final Report, Casd. No. 6860, at If 31-38 (1946).

250 Law Reform (Personal Injuries) Act, 1948, $11 \& 12$ Geo. 6, ch. 41, \& 2. See note 157 supra. The English solution had a forerunner in the Austrian Civil Code of 1811 (now found in sections 1154b and 1156a II, Das Allgemeine Bürgerliche Gesetzbuch [The General Civil Code] (1948)) which provides that an employer, required to pay the cmployee wages during disability, may deduct so much of any social security benefit paid to the employee as is proportioned to his own contribution. This ineans, conversely, that the employee may take a benefit to the extent of his own ratio of contribution.

251 Departmental Committee on Alternative Remedies, Final Report, \$\$ 44-48, Cam. No. 6860 (1946).

252 These sentiments are echoed in the Morris and Paul "supplementary insurance" automobile plan which recommends inter alia, as an off-set to conserve resources for the relief of serious injuries, that the tortfeasor get the advantage of all the accident victim's 
The difference between the British and the original Scandinavian solution remains profound. True, they share the common link of breaking away from the conventional shibboleth of subrogation as a desirable adjunct for the vindication of tort law. Beyond that, however, they differ both in orientation and effect. The Scandinavian discriminates between different classes of tortfeasors, in active promotion of social policies relative to accident prevention and capacity for loss distribution. The British is content with the more abstract choice that Social Security might as well relieve all tortfeasors, whatever the nature of their "wrong"253 or ability to absorb the loss. So muclı for their differences in philosophy.

In actual operation, the two schemes are no less disparate. For all practical purposes, subrogation is of course of no real moment except against insured or institutional defendants. Yet it is precisely against these that subrogation continues to enjoy official sanction in Sweden. In contrast, the principal thrust of the British formula is for Social Security to shoulder a substantial portion of the automobile accident bill. Those who attach great importance to the economic calculus of resource allocation may be tempted to deplore that a particular activity or industry may thus escape paying a portion of its own proper operating costs, thereby distorting the true cost of the economic product. ${ }^{254}$ That the British legislator has not been over-concerned with this is shown by the decision, at the time of abohshing workmen's compensation, henceforth to inake a flat charge for the cost of industrial injury benefits, precisely so that the extra-dangerous industries (which also broadly happened to be those of greatest national importance) thus receive an indirect subsidy. ${ }^{255}$ In any event, this insensitivity for finer discriminations between different "risk communities" is least open to rebuke in case of automobile accidents for

collateral benefits, at least "in relatively trivial cases." This would often keep the tortfeasor froin "setting in motion complicated collection machinery used to get payments for costs which have already been dispersed." Morris \& Paul, The Financial Impact of Automobile Accidents, 110 U. PA. L. REv. 913, 930 (1962).

253 A suggestion to retrench the common law liability of employers to eases of serious misconduct was expressly dismissed by the Monckton Committee. Departmental Committee on Alternative Remedies, Final Remedies, Com. No. 6860, at Iff 75-77 (1946).

254 See Calabresi, Some Thoughts on Risk Distribution, 70 YaIE L.J. 499 (1961).

255 The Beveridge Report had recommended a compromise: a flat rate for all except hazardous industries. The excess cost of the latter was to be borne as to two-thirds by a special levy from the particular employer, the remainder from the general contributions of employers, employees and the State to the Social Insurance Fund. Interdepartmental Committee on Social Insurance and Allied Services, Report, Cam. No. 6404, at If 86-89 (1942). This recommendation was, however, shelved in order to accomplish a complete pooling of risks as in other branches of social insurance. Together with the distinction between ordinary and hazardous industries, it also disclaimed any wish to use differential rates in order to reward or penalize individual enterprises for their past safety performance. See Fusarroro, The Law of Tort and Its Sociar Function 102 (1966). 
the simple, if robust, reason that motor transport represents an activity from which all members of the community benefit in substantial measure. Whether a portion of the accident bill is therefore borne by a social security scheme to which almost all citizens make contributions or by the premium-paying motoring community does not make a great deal of difference, especially when automobile insurance is compulsory and the cost, except in the case of "private" motoring, can be readily passed on as a cost item in the pricing of goods and services. What puts Britain in the vanguard, then, is not so much her commitment to welfare-statism-in which respect she actually lags behind many other Western countries ${ }^{250}$ -as the fact that in this, as in some other respects, ${ }^{257}$ she is content to see some of the accident cost being absorbed by the community at large in relief even of tortfeasors and the special risk community they happen to represent.

\section{Common Law Analogies}

This focus on loss distribution is actually by no means as novel as may perhaps be thought. Most striking evidence of a long recognized bias against shifting loss from insurer to injurer is found in the area of fire damage. ${ }^{258}$ As long ago as $1866 \mathrm{New}$ York established a rule against liability for negligent damage beyond the first building set alight. Far from such spreading fire not being the "probable and natural consequence" of passing trains spewing sparks into adjacent timber-built slums and warehouses, it was precisely because of the frequency of such occurrences that the burden of hability was feared to have a crushing effect on railroading. ${ }^{259}$ The later refusal to extend this rule to rural areas ${ }^{200}$ highlights as the decisive factor that city dwellings (as distinct from crops) are nowadays almost universally insured against fre at cheapest rates and

256 The proportion of the gross national product devoted to cash welfare benefits is only about $7 \%$ in Great Britain, as against $8 \%$ in France, $9 \%$ in Sweden, and $10 \%$ in Germany. Even before medicare, it exceeded $7 \%$ in the U.S.

257 The other major pubhic subsidy of tortfeasors results from the rule in British Transp. v. Gourley, [1956] A.C. 185, which himits damages for loss of income to post-tax earnings, while exempting the award itself from tax liability. In the United States, damages are generally assessed on the basis of gross earnings, combined with not taxing the award. This involves the taxpayer in expense for the sake of conferring a bounty on the tort victin.

258 Kimball and Davis mention fire insurance as the prime candidate for abolishing subrogation. Kimball \& Davis, The Extension of Insurance Subrogation, 60 MIIE. L. REV. 841, 871 (1962).

259 Ryan v. New York Central R.R., 35 N.Y. 210, 91 An. Dec. 49 (1866).

260 In O'Neill v. New York, O. \& W. Ry., 115 N.Y. 579, 22 N.E. 217 (1889), the suggestion was made not to apply the rule to forest fires. When $O$ 'Neill was later repudiated in an 1899 decision, the legislature intervened and restored liability for forest fires without any artificial limitation. N.Y. Conserv. Law $\$ \S 56,63$. See Prosser \& SMITH, Cases oN TORTs, 344-45 (3d ed. 1962). 
that it is economically sounder to let fire insurance bear the loss rather than palm it off on the putative wrongdoer. In this instance, then, subrogation was nullified by manipulating the relevant rule of tort liability.

A little more sophisticated is the formula found in some New England statutes which make the fire insurance carried by the property owner available to the negligent railroad. ${ }^{201}$ Instead of subrogating the insurer to the rights of the insured against the injurer, it subrogates the injurer to the rights of the mjured against the insurer. This mechanism has the great advantage of adjusting itself automatically to whether or not there happens to be insurance in a particular case, im contrast to a general tort rule based on the assumption that most property owners are insured which is unable to make any special allowance for any particular one of them who is not. The same statutory solution was also adopted in the fundamental English reform of property law of 1925 dealing with the familiar problem of fire damage to property between the dates of contract and conveyance. Whereas the American uniform act merely reverses the equity rule that the risk passes at the earlier date, ${ }^{222}$ the English statute requires that the vendor, if insured, hold the policy money in trust for the purcliaser ${ }^{263}$ Some American courts liave followed this lead on their own initiative. ${ }^{264}$

Closely related is the problem of adjusting fire losses between owner and negligent water companies. Courts are about evenly divided over whether the latter slould not be excused for negligent nonfeasance, those favoring immunity preferring that the loss be absorbed by the plaintiff's fire insurer ${ }^{265}$ Here again, at least one court has shown perspicacity and courage in breaking with conventionalism by holding that the water company, even when it had expressly contracted with the insured, should lave its liability reduced by the amount of the insurance. ${ }^{268}$ In effect it

261 Farren v. Maine Central R.R., 112 Me. 81, 90 Atl. 497 (1914); Lyons v. Boston \& L.R.R., 181 Mass. 551, 64 N.E. 404 (1902). Cf., the assinine decision in Rhinehart v. Denver \& Rio Grande R.R., 61 Colo. 369, 158 Pac. 149 (1916), which construed a Colorado statute, proscribing subrogation against railroads, as sanctioning double recovery by plaintiffs.

262 Unzrorar Vendor and Purchaser Risk Act. In California enacted as Car. Crv. CODE $§ 1662$.

${ }^{203}$ Law of Property Act, 1925, $15 \& 16$ Geo. 5, ch. 20, $\$ 47$. In effect this reversed the equity rule which placed the risk on the purchaser and at the saine time denied him the benefit of the vendor's insurance: Rayner v. Preston, $18 \mathrm{Ch} . \mathrm{D} .1$ (1881); Castellain v. Preston, 11 Q.B.D. 380 (1883).

204 In the Matter of Future Mfg. Co-op, 165 F. Supp. 111 (N.D. Cal. 1958), where the case law, which is about equally divided, is thoroughly reviewed.

265 The leading case is H.R. Moch Co. v. Rensselaer Water Co., 247 N.Y. 160, 159 N.E. 896 (1928). See Prosser, TORTS 691 (3d ed. 1964); Gregory, Gratuitous Undertakings and the Duty of Care, I De PaUr L. Rev. 30, 55-67 (1951). There is a strikingly parallel attitude in English decisions. Flendra, Torts 151-2 (3d ed. 1965).

280 Warren Co. v. Hanson, 17 Ariz. 252, 150 Pac. 238 (1915). 
reversed the order of subrogation and gave the benefit of the insurance to the defendant, apparently impressed that otherwise the plaintiff might recover double compensation. ${ }^{267}$ Finally, if only for its irony, it bears mentioning that the fons et origo of the doctrine of subrogation, Lord Mansfield's decision in Mason v. Sainsbury, ${ }^{268}$ subrogating the underwriter to the claim of the insured against the "hundred" for riot damage, was nullified by a statute of $1886^{269}$ which subrogated all such claims against the local authority by plaintiffs who are insured against such risk -thus in effect conferring the benefit of the insurance on the defendant.

\section{CONCLUSION}

In increasing measure, a person who has met wilh an accident may nowadays look for compensation not only to the law of torts but to other collateral sources. The coexistence of several such régimes of compensation im any individual case calls for important decisions as to their relation one to another. Three solutions are open: first, to let the accident victim cumulate the various benefits; second; to shift the ultimate burden of the accident loss to the tortfeasor, relieving as far as possible other compensation funds; third, to credit the tortfeasor with any benefits received from another source.

The first alternative, associated with the "collateral source rule," condones multiple recovery to avoid giving the tortfeasor a "windfall." This extreme position, based largely on obsolete prejudice regarding the function of tort law, has long forfeited all claim to support, except in regard to life and perhaps other forms of private accident insurance which may be regarded as a reward for the plaintiff's own thrift. But in contrast to most other countries which are categorically committed to the compensatory and opposed to the puritive theory of tort damages, American courts continue to entertain an ambiguous and uneasy tolerance of double recovery.

A number of reasons account for this state of affairs. One of them un-

267 Id. at 260, 150 Pac. at 241 .

2883 Doug. K. B. 61,99 E.R. 538 (1782).

269 Metropolitan Police (Compensation) Act, 1886, 49 \& 50 Vict., ch. 11, \$ 2. Ireland, as so often, tells a lesson of how not to do things. Compensation for malicious damage is cast on local authorities which defray it out of local rates (taxes), under the Local Government (Ireland) Act, 1898, 61 \& 62 Vict., ch. 37, $\$$ 5. Indeed, payment of compensation is at critical points of the year often held up to await a new rate levy for this purpose. Standard insurance polices exclude coverage for malicious damage, driving claimants to seek reparation from the county. But since most of the cases involved damage to real property (hy the rehellious peasantry), the ratepayers were the same group as the claimants. As a result, they would pay for it either in the shape of insurance premiums or rates. By choosing the latter, Ireland accepted the more wasteful and senseless alternative, inviting perennial disputes about whether the damage was done "maliciously." 
doubtedly has been the temptation to treat the special case of life insurance as the model for a generalization applicable to all collateral benefits, without inquiring whether the rationale for double recovery lias equal relevance to other benefits. Allied, moreover, to the inertia of precedent which has so far spared the courts from basically reexamining the credentials of the punitive theory of tort damages is the incubus of legal costs having to be met out of tort recoveries. Instead of the successful plaintiff retrieving his legal costs from the defendant, as in most other countries, the system of letting these costs lie where they fall is here evoked as justification for distorting the whole process of loss distribution. It is safe to venture the hunch that, but for this alien intrusion, the rule of double recovery would long ago have been dismissed with contumely, and that its survival is largely due to the conviction that tort damages are never actually sufficient to make the plaintiff whole. ${ }^{270}$

Yet there is evident uneasimess about this result. That double recovery runs against the grain is attested by the never-ebbing volume of appeals from contrary rulings at trial, ${ }^{271}$ by the widespread impression that juries would lean the other way, ${ }^{272}$ by the fact that it is anathema in the closely related context of recoveries from co-tortfeasors, ${ }^{273}$ and by the evident judicial distaste for extending it to borderline situations, sucl as cases of contractual liability. ${ }^{274}$ Perhaps the strongest evidence of its waning

270 There are occasional manifestations of judicial candor in this respect. See, e.g., Hudson v. Lazarus, 217 F.2d 344, 346 (D.C. Cir. 1954). But see Chief Judge Lumbard's refusal to accept it as an argument for using pre-tax earnings as a base for calculating economic loss. McWeeney v. N.Y., N.H. \& H.R.R., 282 F.2d 34, 43 (2d Cir. 1960) (dissent).

271 There are more than a hundred appellate cases alone on whether private insurance is collateral.

272 Disclosure of collateral benefits ostensibly for some other legitimate purpose (for example, to impeach the plaintiff's testimony regarding permanency of his injuries) has been repeatedly condemned as too prejudicial. See, e.g., Eichel v. New York Cent. R.R., 375 U.S. 253 (1964); McElwain v. Capotosto, 332 Mass. 1, 122 N.E.2d 901 (1954). Why?

273 UnIForar Contribution Among TortFeasors Act \& 4(a). The same rule applied at comnion law. See, e.g., Laurenzi v. Vranizan, 25 Cal. 2d 806, 155 P.2d 633 (1945); Prosser, Torts 267 (3d ed. 1964).

274 E.g., United Protective Workers v. Ford Motor Co., 223 F.2d 49, 54 (7th Cir. 1955) (defendant who has breached contract is not a "wrongdoer in the tort sense"; "tort law has a flavor of punitive damages"). Perhaps the most significant aspect of the well-known decision of Anheuser-Busch Co. v. Starley, 28 Cal. 2d 347, 170 P.2d 448 (1946), is that the majority and Justice Traynor (dissenting) linked hands in their determination that the shipper should in no circumstances have double recovery. While Justice Traynor argued that the shipper, having been fully conpensated by the carrier, should be barred from any further claim against the tortfeasor, the majority gave him the benefit of the collateral source rule on the understanding that double recovery was precluded by the shipper's right of subrogation. Justice Traynor treated the carrier and defendant as co-tortfeasors; the majority treated the carrier as analogous to an insurer. All agreed that, if the carrier was found negligent, the tortfeasor could resist hability, whether the action was brought in the 
strength is the increasing number of situations in which the accident victim must eventually disgorge the excess, so that the collateral source rule becomes a vehicle not for his enrichment but for the shifting of the loss from the tortfeasor to the collateral source.

Two most perplexing features haunt the present state of American law. One arises directly from the last-mentioned fact that such reimbursement to the other fund cannot in general be technically accomplished without the aid of the collateral source rule, that is, precluding the tortfeasor from arguing that his liability has been reduced by the collateral subvention. Thus, whereas the collateral source rule is often enough invoked by courts wholly indifferent as to whether this will result in double recovery, there are others which at least condone it on the ground that, in the individual case, double recovery will be avoided by subrogation or some other like technique for passing the excess on to the collateral source. Finally, one also occasionally encounters a court purposefully insisting on the collateral source rule precisely in order to accomplisi such a shifting of the loss.

Turning from double recovery to a consideration of other alternatives, we note that these differ from the former in posing a decision as to which of two sources of compensation to treat as the primary and which as the secondary. In contrast to cumulation of benefits, they force a confrontation with a basic policy orientation whether accident losses generally, or any particular accident loss, should be absorbed by the tortfeasor or by a collateral source, whether in accordance with the régime of tort law or the régime of private or social insurance. It calls for a fixing of priorities pursuant to relevant contemporary social and economic values as to loss allocation. In particular, the following criteria can be isolated as most important in their bearing on this assignment: (1) the reprehensiveness of the defendant's conduct, (2) the desirability of attributing the cost to the loss-causing enterprise for reasons of accident-prevention, proper cost allocation, etc., and (3) the function and, more important still, the economic base of the particular collateral compensation régime.

Not surprisingly, the predominant response has been to regard the tortfeasor as the primary source of compensation. Imbued with the philosophic values of a culture that has traditionally regarded tort law as the only and proper system for allocating accident losses, it is still widely considered as almost axiomatic that if an injurer's conduct justifies his

name of the carrier or (satisfied) shipper. Note that all this happened before California introduced contribution hetween tortfeasors in 1957. CAI. Code of Crv. Proc. § 875 .

The California Supreme Court's aversion to double recovery manifested in Anheuser. Busch and other cases (e.g., cases listed in note 106 supra) was not shared hy the Ninth Circuit Court of Appeal, which held the collateral source rule applicable even against a non-negligent defendant. Gypsum Carriers Inc. v. Handelsman, 307 F.2d 525 (9th Cir. 1962) (shipowner liable for maintenance and cure). 
being coinpelled to relieve the injured from the loss he has inflicted, it is also sufficient reason for his relieving anybody else who might otherwise have undertaken the job of reparation. This approach, dominated by lingering notions of prolnoting an individualistic morality against "wrongdoers, ${ }^{2275}$ is reinforced by the impression that it would also reduce the cost to the commumity in general, and the plaintiff in particular, in mamtaining the collateral fund. It is strongest in cases of private insurance, where to reduce the tortfeasor's liability would look hike diverting the fruit of the plaintiff's own thrift into the pockets of one who least "deserves" it; but it has also found ardent advocates among social security organizations ever watchful to save the public purse. ${ }^{276}$

These primarily moralistic postulates are gradually yielding in their appeal to an economic value system which places in the forefront the high collection costs of reshifting the loss from a collateral source to the tortfeasor, the attendant wastefulness of multiple insurance and, most important of all perhaps, an awareness that in these days, when tort hability qualifies as a significant source of compensation only in case of defendants who can pass on the loss through liability insurance or pricing of their goods or services, the question is not so mucli whether a wrongdoer deserves to be relieved as which of several competing "risk communities" should bear the loss. Loss-bearing has become collectivized, whether it falls on the defendant or some other régime, like insurance or social

275 Even among tortfeasors, it is familiar doctrine to discriminate between one guilty of fault and another liable for faultless causation. This explains the right of indemnity accorded to the latter against the former even in jurisdictions that do not allow so much as contribution between tortfeasors. See Prosser, Toris 278-81 (3d ed. 1964). The Swiss Code of Obhgations reveals the same policy in an interesting order of priority enacted in Article 51: first comes liability based on fault, second contractual liability (including insurance), and third liability imposed by law on a fault-free obligor. Thus a carrier is not only entitied to shift the loss to a negligent tortfeasor, but also to the plaintiff's insurer. See 1 OFITIGER, SchweJzertsches HAFTPFITCETRECFT 306 (2d ed. 1958). This does not represent our own model in all aspects. We would allow a complete indemmity even to a negligent claimant against one contractually bound to indemnify him for breach of warranty; thus, $D-1$ 's neghigent failure to inspect equipment procured from $D-2$ would not defeat his claim against $D-2$ for damages that lie $(D-1)$ had to pay a third party.

270 The strength of this bias finds a salient illustration in Canadian history. For a time, provincial governments appear to have been content to see tortfeasors take the benefit of free hospital services provided to plaintiffs under provincial insurance plans. This was the result of the prevailing "Englisln" rule that plaintiffs can recover only for medical expenses actually incurred. See, e.g., Schaeffer v. Mish, [1950] 4 D.L.R. 648 (Sask.); Flaherty v. Hughes, [1952] 4 D.I.R. 43 (B.C.); Vermett v. Winning, 26 D.I.R.2d 765 (Man. 1960). But when the federal government assumed part of the financial burden of the hospital scheme, it imposed the condition that each province provide for the recovery of the cost of insured services from tortfeasors. Hospital Insurance and Diagnostic Services Act, 1957, $5 \& 6 \mathrm{Eliz}$, ch. 28, \& 5(2)(d) (Can.). All provinces have either by statute or regulation complied. See Grant v. Stewart, 48 D.L.R.2d 650 (N.S. 1964). 
security, to fill the role as conduit for distribution. While this focus does not provide ready-made solutions, still less generally valid answers, it stimulates a probe all along the line whether in any particular case there is sufficient justification for going to the trouble and expense of shifting the loss to the tortfeasor from some other regime that has already footed the bill and could as well or even better absorb it. Social security, for example, because of its broad base of contributors, has a strong claim for displacing pro tanto any "risk pool" represented by tort defendants. On the other hand, very special hazards presented by certain enterprises (for example, nuclear power stations) may make it advisable, for reasons of proper economic cost allocation as well as in the interest of maximizing accident prevention, to assign the ultimate loss to that enterprise rather than spread it on a broader base where these advantages would be lost. If deterrence in the old crude sense has any continuing appeal as a justification for tort liability, it will be confined to situations where it can realistically perform an admonitory function, namely, only against defendants guilty of serious misconduct. Somewhat paradoxically, tort law would shrink, at least in this respect, to its original starting-point as an adjunct of the criminal law in sanctioning immoral conduct. ${ }^{277}$ In several European countries, especially Scandinavia and Britain, vast encroachments on the erstwhile primacy of tort liability have already taken place along these lines. In the United States, this process of emancipation from the paralyzimg legacy of largely obsolete folklore is still in its infancy, but is bound to gain increasing momentum as social security and other collateral régimes are assuming a greater role in the business of meeting accident costs. ${ }^{278}$

$\mathbf{2 7 7}$ See Friedmann, Principles of Tort Liability and the Grouth of Insurance, in INTERNationates Verischerungsrecht (Festschrift Für. A. Ehrenzweig) 24-39 (Möeller ed. 1955), where the author concludes: "The result would be that, for a very limited splere, the law of tort would come closer again to criminal law in sanctioning immoral conduct, while for the vast number of accidents due to modern social conditions, tort might either . . frankly become a matter of strict liability or be superseded by insurance." Id. at 39.

278 To avoid any conceivable misunderstanding, "collectivization of losses" has nothing whatever to do with socialism. Socialism in its proper signification denotes a system of public ownership of the means of production. And, even if this phrase were to be understood in the more general sense as an antonym of individualism, the very existence of liability insurance has undermined the notion that tort liability would promote individual responsibility. Liability insurance spreads, and therefore "collectivizes," or "pools," losses just as much, though not necessarily as widely, as social security. Nor does the trend towards increasing social security mean socialism: it means welfare-statism, an entirely different breed of cat.

Socialist law is in fact inore deeply wedded to the old-fashioned admonitory purpose of tort than any present-day bourgeois system. Indeed the trend is hardening. Under the pre-1962 Civil Code (art. 413) a person or enterprise paying insurance premiums to protect the injured person under social insurance was exempt from all liability, including indemnity to the insurance fund, except when guilty of criminal negligence-just as em- 
In the upshot, there is thus emerging a second tier of principles of loss allocation; the first being concerned with the traditional problem of whether the person injured should be compensated at all, and the second with whether the tortfeasor rather than some other available fund should bear the ultimate burden of compensation. As a result, in many instances tort liability will become only an excess or a guarantee hability, its function being merely to allot responsibility for compensation to a person (labelled 'tortfeasor') to the extent that the cost of compensation has not been met by another source.

In many ways this development represents a much more dramatic innovation than the sensational trend of recent years towards strict liability in the consumer protection area. It is more important by far because it adds an entirely new element to the grammar of loss allocation. Tort hability has ceased to be the sole point of reference in any inquiry, legislative or judicial, as to how particular accident losses should be absorbed. The iminediacy of this changing viewpoint is already becoming apparent in the currently renewed debate over the perennially vexing problem of autornobile accidents. ${ }^{279}$

ployers are under our own system of workmen's compensation. Under the 1962 Principles of Civil Legislation, lowever, the employer is not only liable to the injured workman for any excess of loss over his social security benefits (art. 91), but must also reimburse the social security fund (art. 94). Evidently the Soviet legislator clings to the conviction that tort law should continue to serve, in conjunction with criminal sanctions, the object of deterring and penalizing carelessness as well as more serious misconduct. Collectivizing, or pooling, losses would obviously frustrate such an individualistic purpose. Hence, there is right of reimbursement for social security and the prohibition of liability insurance for motorists. Cf., Hazard, Personal Injury and Soviet Socialism, 65 HARv. L. REv. 545 (1952), whose insights lave not lost their meaning from lapse of time and the intervening new legislation.

279 See Blum \& Karven, Public Law Perspectives on a Private Law Probtema (1965). See also a reply by Calabresi, Fault, Accidents and the Wonderful World of Bhim and Kalven, 75 YATE L.J. 216 (1965). 